\title{
Geochronology, geochemistry and tectonic significance of the late Mesozoic volcanic sequences in the northern Wuyi Mountain volcanic belt of South China
}

\author{
Xiong Yan ${ }^{\mathrm{a}}$, Shao-Yong Jiang ${ }^{\mathrm{a}, \mathrm{b}, *}$, Yao-Hui Jiang ${ }^{\mathrm{a}}$ \\ ${ }^{a}$ State Key Laboratory for Mineral Deposits Research, School of Earth Sciences and Engineering, \\ Nanjing University, Nanjing 210093, China \\ ${ }^{\mathrm{b}}$ State Key Laboratory of Geological Processes and Mineral Resources, Collaborative Innovation \\ Center for Exploration of Strategic Mineral Resources, Faculty of Earth Resources, China \\ University of Geosciences, Wuhan 430074, China
}

Corresponding author: shyjiang@nju.edu.cn and shyjiang@cug.edu.cn

\begin{abstract}
The widespread occurrence of late Mesozoic volcanic rocks in the Gan-Hang Belt in South China is associated with similarly widespread mineralization, but many important questions surrounding these volcanic rocks have not been clearly answered. The Tianhuashan basin located in the northern Wuyi Mountain volcanic belt is one of the most important volcanic basins in the Gan-Hang Belt, and it is primarily composed of the Daguding and Ehuling Formations and their intrusive counterparts. LA-ICP-MS zircon U-Pb dating shows that the Daguding Formation erupted in the Late Jurassic (152-160 Ma), whereas the Ehuling Formation erupted in the Early Cretaceous (131-139 Ma) in the Tianhuashan basin. Volcanic rocks are rhyolite and share similar trace and rare earth element patterns with an enrichment of LREEs and a depletion in $\mathrm{Sr}, \mathrm{Ba}, \mathrm{Nb}$, $\mathrm{Ta}, \mathrm{P}, \mathrm{Eu}$ and Ti. They are also characterized by negative whole rock $\varepsilon_{\mathrm{Nd}}(\mathrm{t})$ and zircon $\varepsilon_{\mathrm{Hf}}(\mathrm{t})$ values with Paleoproterozoic $\mathrm{t}_{2 \mathrm{DM}}$ ages, suggesting that they were derived primarily from the remelting of ancient crustal materials. Daguding volcanic rocks are strongly peraluminous and show a higher Mg\# than pure crustal melts, implying that they were likely derived from Paleoproterozoic metasedimentary basement materials. However, Ehuling volcanic rocks are weakly peraluminous and have a pronounced $\mathrm{A}_{2}$-type geochemical signature. Detailed elemental and isotopic data suggest that they were formed by the partial melting of the Paleoproterozoic metamorphic basement (including metasedimentary and metaigneous rocks) at a high temperature $\left(\sim 840^{\circ} \mathrm{C}\right)$, followed by fractional crystallization. These results imply that during the Late Jurassic, South China on the Gan-Hang Belt was a continental arc coupled with the subduction of the Paleo-Pacific plate. Since the beginning of the Early Cretaceous, an intra-arc rift has formed along the Gan-Hang Belt as a consequence of slab rollback. These results also indicate that the extension in the Gan-Hang Belt began later than the southwestern part of the Shi-Hang Zone and lasted from
\end{abstract}


139 Ma to 122 Ma.

\section{Keywords:}

Late Mesozoic volcanism; Petrogenesis; Tectonic setting; Northern Wuyi Mountain volcanic belt; South China

\section{Introduction}

During the Late Mesozoic period, magmatic rocks were extensively developed in South China, most of which were granites and their volcanic counterparts (Zhou et al., 2006). Their ages, petrogenesis, tectonic settings and geodynamics have been the focus of many studies over the last few decades (Chen and Jahn, 1998; He et al., 2010; Hsü et al., 1988; Hsü et al., 1990; Jiang et al., 2006; Jiang et al., 2008; Jiang et al., 2009; Jiang et al., 2011; Lapierre et al., 1997; Li and Li, 2007; Li et al., 2014; Qi et al., 2013; Wang et al., 2013; Wong et al., 2009; Wong et al., 2011; Xu, 2008; Yang et al., 2012; Yu et al., 2006; Zhou and Li, 2000; Zhou et al., 2006). Although volcanic rocks are well developed and widely distributed in South China, as an important part of the coastal area within China and even the circum-Pacific volcanic belt, they have received much less attention than granites (e.g., Wang et al., 2013; Guo et al., 2012; Jiang et al., 2005; Su et al., 2014; Yang et al., 2011; Yang et al., 2013). However, these volcanic rocks contain important information about the chronologic framework and petrogenesis of multistage magmatism and could shed new light on the detailed geodynamic evolution and tectonic regimes in this region.

The northern Wuyi Mountain volcanic belt is an important volcanic rock belt in South China, which is controlled by basement uplift from the northeast towards the southwest. A series of volcanic basins has developed along this belt (such as Tianhuashan, Huanggangshan, and Tongboshan), accompanied by abundant magmatism-related polymetallic mineral deposits (Huang et al., 2012; Meng et al., 2012; Zhang et al., 2009; Zhang et al., 2012). As an important component of this belt, the Lengshuikeng ore field in the Tianhuashan volcanic basin is a super large $\mathrm{Ag}-\mathrm{Pb}-\mathrm{Zn}$ polymetallic mineral deposit, and it has attracted considerable attention from many geologists worldwide. It is generally believed that mineralization is closely related to late Mesozoic magmatic activity. However, previous studies have focused primarily on the geochronological aspects of the ore-related granitoid rock (Huang, 1993; Meng et al., 2009; Meng et al., 2012; Qiu et al., 2013; Su et al., 2014; Wang et al., 2013; Xu et al., 2002; Zuo et al., 2008; Zuo et al., 2010). Because the host rock is Mesozoic volcanic rock, the precise and accurate isotopic age determination of the rocks is crucial not only for the geologic time of Late Mesozoic volcanism and associated tectonic events but also for the origin of the Lengshuikeng $\mathrm{Ag}-\mathrm{Pb}-\mathrm{Zn}$ polymetallic mineral deposit. Furthermore, the origin of these volcanic rocks and the processes involved in their formation provide an opportunity to reveal the late Mesozoic tectonic evolution of the northern Wuyi Mountain metallogenic belt. It is thus apparent that the petrogenetic characteristics of volcanic rocks need to be studied in much greater detail to further understand the Late Mesozoic magmatic activity and the process of crust-mantle interaction in the northern Wuyi Mountain area. 
In this study, two drill holes accompanied by several outcrops, which contain both of the volcanic formations (Daguding Fm. and Ehuling Fm.), were selected as the most suitable sites for a comprehensive study of the volcanism in the Tianhuashan volcanic basin. We present precise zircon $\mathrm{U}-\mathrm{Pb}$ ages, along with major and trace elements and $\mathrm{Sr}-\mathrm{Nd}-\mathrm{Hf}$ isotopic compositions for volcanic rocks, in an attempt to better constrain the ages and petrogenetic processes involved and to shed new light on the geodynamic setting of Late Mesozoic tectonics and magmatism in the northern Wuyi Mountain area.

\section{Geological background}

The South China Block has a complex tectonic evolution history, and it is composed of two major Precambrian continental blocks: the Yangtze Block in the northwest and the Cathaysia Block in the southeast. The two blocks are divided by the Gan-Hang tectonic belt (Gilder et al., 1996; Yu et al., 2006), a tectonic suture zone between the Yangtze and Cathaysia blocks, which starts from Shaoxing, Zhejiang Province in the northeast and extends to Yongfeng, Jiangxi Province in the southwest (Fig. 1).The Late Mesozoic period is characterized by the multistage eruption of volcanic rocks and their intrusive counterparts in South China, resulting in the extensive emplacement of a series of Late Mesozoic volcanic-intrusive complexes in South China, which have been conventionally divided into three major stages from the early to late Yanshanian: 180-160 Ma, 160-135 Ma and 135-90 Ma. Among these, felsic rocks are volumetrically dominant, whereas mafic rocks (e.g., basalts, gabbros, andesites and syenites) are relatively rare ( $\mathrm{Li}$ and $\mathrm{Li}$, 2007; Li, 2000; Zhou and Li, 2000).

The Tianhuashan basin, which contains a super large $\mathrm{Ag}-\mathrm{Pb}-\mathrm{Zn}$ polymetallic mineral deposit (Lengshuikeng deposit) in the northwestern margin, is geographically located on the border of the Jiangxi and Fujian provinces. Tectonically, it is located in the northeast corner of the Cathaysia Block and is bounded by the Jiangshan-Shaoxing suture zone to the north and the Yingtan-Anyuan Fault to the west. It is a member of the northern Wuyi Mountain volcanic belt adjacent to the southern margin of the Gan-Hang tectonic belt. This belt is composed of a number of NNE-trending Mesozoic extensional volcanic basins, such as the Tianhuashan, Huanggangshan and Tongboshan basins (Fig. 1). The Tianhuashan basin shows an ellipsoidal shape and is approximately $50 \mathrm{~km}$ long and $40 \mathrm{~km}$ wide, covering an area of approximately $1500 \mathrm{~km}^{2}$. It is one of the largest volcanic basins in the region and is composed of the Tiantaishan and Yuefengshan sub-basins.

The stratigraphic sequence in the basin is summarized in Table 1 . The basement of the Tianhuashan basin consists of a metamorphic complex including biotite quartz schists, quartz-biotite schists and biotite plagioclase gneisses of the Neoproterozoic Sinian period. The Paleozoic strata are sporadically distributed at the margins of the basin with a carboniferous system that primarily consists of quartz conglomerate and sandstone of the Zishan Fm. at the bottom and limestone of the Huanglong Fm. at the top. The Huanglong Fm. is discordantly overlain by the late Mesozoic volcanic rocks, which can be divided into two magmatic cycles: the early stage Daguding Fm. and the late-stage Ehuling Fm. The Daguding Fm. volcanics are composed of two distinguishing members. The lower member consists of rhyolitic crystal tuff, rhyolitic ignimbrite and tuff, whereas most of the upper member consists of andesite, which is the marker bed of the Daguding Fm. The Ehuling Fm., which shows discordant contact with the 
underlying Daguding Fm., is extensively exposed throughout the basin, and it can be divided into three members in light of their eruption cycles and specific rock types. The first member primarily consists of rhyolitic crystal tuff and ignimbrite with tuffaceous sandstone at the bottom. The second member is composed primarily of rhyolite and ignimbrite with tuffaceous siltstone at the bottom. The major rock types of the third member are rhyolitic ignimbrite with tuff at the bottom.

In the Lengshuikeng district, the Ehuling Fm. outcrops continuously in accordance with the northeast towards the nappe structure, whereas the Daguding Fm. is barely exposed (Fig. 2). Since the late 1960s, many geological investigations have been conducted, and a number of giant $\mathrm{Ag}-\mathrm{Pb}-\mathrm{Zn}$ polymetallic mineral deposits have been explored in this area. According to their mineralization characteristics, these deposits are generally classified into two types: the porphyry type, which exists within the granite porphyry and the periphery of the rock, and the stratabound type, which occurs within the layered volcanic rocks of the Daguding Fm. and the Ehuling Fm. beneath the porphyry type. The former includes Yinluling, Yinzhushan, and Baojia deposits, whereas the latter includes Xiabao, Yinglin, and Yinkeng deposits. As an important component of the Northern Wuyi Mountain metallogenic belt, the Lengshuikeng ore district has attracted considerable attention from many geologists since the discovery of the polymetallic mineral deposits, but the exact timing of the volcanic units remains controversial, and further investigations are required to clarify the geochronological framework. The first published geochronological data of the volcanic units suggest an age of $101 \mathrm{Ma}$ for the Ehuling Fm. and an age range of $112 \mathrm{Ma}$ to $123 \mathrm{Ma}$ for the Daguding Fm. on the basis of the Rb-Sr and K-Ar method, respectively (Xu et al., 2001). The age of the Ehuling Fm. was updated to 129.7 Ma in 2002 (Xu et al., 2002). However, in situ zircon U-Pb, the dating results demonstrate that the eruption time of the Daguding Fm. was approximately 157 to 161 Ma, but the Ehuling Fm. shows conflicting ages, between 146.6 Ma and 161.8 Ma (Meng et al., 2012; Qiu et al., 2013; Wang et al., 2013; Xu et al., 2013). Recently, Su et al. (2014) reported that both the Daguding Fm. and the Ehuling Fm. formed in the Early Cretaceous ( 144-137 Ma) based on zircon U-Pb ages. Hence, correct sampling and precise and accurate isotopic age determination is urgent and crucial for the geologic time of Late Mesozoic volcanism and for understanding the relationship between the volcanic rocks and the mineralization in the region.

Multiple stages of intrusive activities ranging from the Caledonian to Yanshanian periods occurred in this area. Except for the vastly exposed Caledonian migmatitic granites in the northwest part of the district, the rest can be divided into two main stages. The early stage is represented by Late Jurassic granite porphyry, which is primarily distributed in the center part of the basin and is associated with mineralization; the latter is represented by the Early Cretaceous granitoids, which are composed of quartz syenite porphyry, rhyolite porphyry and K-feldspar granite porphyry and are extensively developed throughout the basin. There are distinct, intrusive relationships among the early granite porphyry, the late rhyolite porphyry, the K-feldspar granite porphyry, and all of these intrusions and volcanic units on the geological map (Fig. 2). 


\section{Samples and analytical methods}

\subsection{Samples and petrography}

The samples for this study were primarily collected from two drill cores along with the representative sections of volcanic units in the Lengshuikeng district. The light gray-green crystal tuff from the lower segment of the Daguding Fm., which was collected from the drill core ZK15150 and ZK15701, with one from the 188-2 footrill, consists of broken crystal fragments (45\%-60\%), volcanic ash and vitroclasts (Fig. 3a, b, c). The crystals are quartz and plagioclase, and a few are biotite. These samples show slightly pervasive hydrothermal alteration, such as chloritization, sericitization, silicification and carbonization. The biotite was replaced by chlorite or broken down to muscovite and $\mathrm{Fe}-\mathrm{Ti}$ oxides along their cleavage planes and crystal margins (Fig. 3b). The feldspar fragments changed into a complex of sericite, chlorite, and carbonate (Fig. $3 \mathrm{a}, \mathrm{b}, \mathrm{c})$.

Samples from the Ehuling Fm., which were collected from the drill core ZK15701 and outcrops, consisting of lithoclasts (5\%-10\%), crystals (5\%-15\%), vitroclastic and volcanic ash (Fig. $3 \mathrm{~d}, \mathrm{e}, \mathrm{f})$. The lower segment is light gray-green, whereas the upper segment is flesh pink. The crystals are quartz, and a few are plagioclases. The quartz has undergone corrosion to varying degrees with an irregular harbor shape, and some were clearly broken into smaller pieces (Fig. 3e). Argillic alteration is notable in some feldspar grains, and several samples show obvious ignimbrite texture and pseudofluidal structure (Fig. 3f). More detailed information about the lithologies, pyroclast assemblages and GPS positions of the studied samples are given in Table 2.

\subsection{Zircon $\mathrm{U}-\mathrm{Pb}$ and $\mathrm{Hf}$ isotope analyses}

Zircon grains were separated from the volcanic rock samples through crushing, conventional magnetic and heavy liquid separation methods followed by handpicking under a binocular microscope. The selected grains were then mounted on adhesive tape, enclosed in epoxy resin, and polished to approximately $1 / 3$ to $1 / 2$ their thickness for analysis. Cathodoluminescence (CL) images of the zircon grains were taken using a Mono CL3 detector (manufactured by Gatan, U.S.A.) attached to a scanning electron microscope (manufactured by JSM6510, JEOL, Japan) at the Beijing Geoanalysis Co., Ltd. These images helped select suitable spots for in-situ U-Pb dating and $\mathrm{Lu}-\mathrm{Hf}$ analysis.

The zircon U-Pb analyses were conducted using the LA-ICP-MS method at the State Key Laboratory for Mineral Deposits Research at Nanjing University, using an Agilent 7500a ICP-MS equipped with a New Wave Research $213 \mathrm{~nm}$ laser ablation system. The ablated material was transported in a He carrier gas through $3 \mathrm{~mm}$ i.d. PVC tubing and then combined with Ar in a 30 $\mathrm{cm}^{3}$ mixing chamber prior to entering the ICP-MS for isotopic measurement.

Fractionation and instrumental mass biases were corrected by direct calibration against a homogeneous zircon standard, GEMOC/GJ-1 (608.5 Ma; Jackson et al., 2004), analyzed under carefully matched conditions. Samples were analyzed in 'runs' of ca. 15 analyses, which included 11 unknowns and were bracketed by two analyses of the standard. The unknowns included one analysis of an external zircon standard, Mud Tank (732Ma) (Black and Gulson, 1978), as an 
independent control on reproducibility and instrument stability. The counting time for one analysis was typically $100 \mathrm{~s}$ (40 s measuring gas blank to establish the background and $60 \mathrm{~s}$ for the remainder of the analysis). The repetition rate of the laser was $5 \mathrm{~Hz}$, with a fluence of approximately $20 \mathrm{~J} / \mathrm{cm}^{2}$. The spot size varied between 25 and $35 \mu \mathrm{m}$ in diameter according to the sizes of zircon grains. Detailed analytical procedures were similar to those described by Jackson et al. (2004). The raw ICP-MS data were exported in ASCII format and processed using GLITTER (Van Achterbergh et al., 2001). Common lead contents were corrected using the method of Andersen (2002). The age calculations and plotting of Concordia diagrams were performed using Isoplot 3 (Ludwig, 2003).

Zircon Lu-Hf isotope analysis was conducted on the same spot or in the same domain of previous $\mathrm{U}-\mathrm{Pb}$ analyses according to the CL images, using a New Wave UP193FX laser ablation microprobe attached to a Neptune multi-collector ICP-MS in the same lab at Nanjing University. The instrumental conditions and data acquisition were similar to those described by $\mathrm{Wu}$ et al. (2006) and Hou et al. (2007). Analyses were performed predominantly with a beam diameter of 35 $\mu \mathrm{m}$ and a repetition rate of $8 \mathrm{~Hz}$. Both $\mathrm{He}$ and Ar carrier gases were used to transport the ablated sample from the laser-ablation cell via a mixing chamber to the ICP-MS torch. Atomic masses 172, 173,175 to 180 and 182 were simultaneously measured in the static-collection mode. Corrections for isobaric interferences of ${ }^{176} \mathrm{Yb}$ and ${ }^{176} \mathrm{Lu}$ on ${ }^{176} \mathrm{Hf}$ referred to Iizuka and Hirata (2005), Wu et al. (2006) and Hou et al. (2007). The reference zircon Mud Tank $\left({ }^{176} \mathrm{Hf} /{ }^{177} \mathrm{Hf}=0.282507 \pm 6\right.$; Woodhead and Hergt, 2005) and the standard zircon 91500 (Wiedenbeck et al., 1995) were used to monitor performance conditions and analytical accuracy.

The initial $\mathrm{Hf}$ values (in term of $\varepsilon_{\mathrm{Hf}}$ ) were calculated using a decay constant of $1.867 \times 10^{-11}$ per year (Söderlund et al., 2004) for ${ }^{176} \mathrm{Lu}$ and a chondritic model with ${ }^{176} \mathrm{Hf} /{ }^{177} \mathrm{Hf}=0.282785$ and ${ }^{176} \mathrm{Lu} /{ }^{177} \mathrm{Hf}=0.0336$ (Bouvier et al., 2008). Depleted mantle Hf model ages $\left(\mathrm{T}_{\mathrm{DM}}\right)$ were calculated using the measured ${ }^{176} \mathrm{Lu} /{ }^{177} \mathrm{Hf}$ ratios of zircon, referring to a model of depleted mantle with a present-day ${ }^{176} \mathrm{Hf} /{ }^{177} \mathrm{Hf}$ ratio of 0.28325 , similar to that of an average MORB (Nowell et al., 1998) and ${ }^{176} \mathrm{Lu} /{ }^{177} \mathrm{Hf}=0.0384$ (Griffin et al., 2000). "Crustal" model ages $\left(\mathrm{T}_{\mathrm{DM} 2}\right)$ were also calculated by projecting the initial ${ }^{176} \mathrm{Hf} /{ }^{177} \mathrm{Hf}$ ratios of the zircon to the depleted mantle model growth line using a mean ${ }^{176} \mathrm{Lu} /{ }^{177} \mathrm{Hf}$ value $(0.015)$ for the average continental crust (Griffin et al., 2002).

\subsection{Major and trace element analysis}

Because surface-exposed volcanic rock is more prone to late surface weathering, fifteen unaltered or slightly altered samples from drill hole 15701 and drill hole 15150 were chosen for bulk-rock geochemical analysis. The locations of the two drill holes are shown in Fig. 2. The whole-rock samples were crushed and ground to 200-mesh using an agate ring mill.

All major and trace elements analyses for the samples were conducted at the State Key Laboratory for Mineral Deposits Research in Nanjing University. The major elements were determined by wavelength-dispersive X-ray fluorescence spectrometry (XRF) on fused glass, following a procedure described by Norrish and Hutton (1969) and with analytical uncertainties better than $0.5 \%$. For trace element analyses, approximately $50 \mathrm{mg}$ of the powered sample was digested using an $\mathrm{HF}+\mathrm{HNO}_{3}$ mixture in high-pressure Teflon bombs at $190{ }^{\circ} \mathrm{C}$ for $72 \mathrm{~h}$. $\mathrm{Rh}$ was used as an internal standard to monitor signal drift during ICP-MS measurement. The trace 
elements were measured using Finnigan Element II inductively coupled plasma mass spectrometry (ICP-MS). Standards and duplicated analyses indicated that the precisions of trace element analyses were generally better than $5 \%$, and the accuracies were better than $10 \%$. Detailed analytical procedures have been outlined previously in Gao et al. (2003).

\subsection{Whole-rock Sr-Nd isotope analysis}

The $\mathrm{Sr}$ and $\mathrm{Nd}$ isotopic compositions were analyzed using Finnigan Triton TI thermal ionization mass spectrometry (TIMS) at the State Key Laboratory for Mineral Deposits Research in Nanjing University. Samples of approximately $100 \mathrm{mg}$ were dissolved in the same way as for trace element analyses. The complete separation of $\mathrm{Sr}$ was accomplished by a combination of cation-exchange chromatography in $\mathrm{H}^{+}$form and pyridinium form with the DCTA complex. $\mathrm{Nd}$ was then separated from the REE fractions by cation-exchange resin using HIBA as a cation exchange medium. After purification, the separated $\mathrm{Sr}$ was dissolved in $1 \mu \mathrm{L}$ of $1 \mathrm{~N} \mathrm{HCl}$ and then loaded with $\mathrm{TaF}_{5}$ solution onto pre-conditioned $\mathrm{W}$ filaments for ${ }^{87} \mathrm{Sr} /{ }^{86} \mathrm{Sr}$ analysis on TIMS. The separated $\mathrm{Nd}$ was dissolved in $1 \mu \mathrm{L}$ of $1 \mathrm{~N} \mathrm{HCl}$ and then loaded with phosphate acid onto Re double-filaments for $\mathrm{Nd}$ isotope analysis on TIMS. The $\mathrm{Sr}$ and $\mathrm{Nd}$ isotopic ratios were corrected for mass fractionation relative to the natural ${ }^{86} \mathrm{Sr} /{ }^{88} \mathrm{Sr}=0.1194$ and ${ }^{146} \mathrm{Nd} /{ }^{144} \mathrm{Nd}=0.7219$, respectively. During the course of this study, measurements of NIST SRM-987 Sr standard yielded an ${ }^{87} \mathrm{Sr} /{ }^{86} \mathrm{Sr}$ ratio of $0.710252 \pm 0.000016(2 \sigma)$, and the JNdi-1Nd standard yielded a ${ }^{143} \mathrm{Nd} /{ }^{144} \mathrm{Nd}$ ratio of $0.512121 \pm 0.000016(2 \sigma)$. More details on the analytical procedures are given in $\mathrm{Pu}$ et al. $(2004,2005)$. We used the following parameters to calculate the $\mathrm{I}_{\mathrm{Sr}}, \varepsilon_{\mathrm{Nd}}(\mathrm{t})$ values and Nd model ages: $\lambda_{\mathrm{Rb}}=1.42 \times 10^{-11}$ year $^{-1}$ (Steiger and Jäger, 1977); $\lambda_{\mathrm{Sm}}=6.54 \times 10^{-12}$ year $^{-1}$ (Lugmair and Marti, 1978); $\quad\left({ }^{147} \mathrm{Sm} /{ }^{144} \mathrm{Nd}\right)_{\mathrm{CHUR}}=0.1967 \quad$ (Jacobsen and Wasserburg, 1980); $\left({ }^{146} \mathrm{Nd} /{ }^{144} \mathrm{Nd}\right)_{\mathrm{CHUR}}=0.512638$ (Goldstein et al., 1984); and $\left({ }^{146} \mathrm{Nd} /{ }^{144} \mathrm{Nd}\right)_{\mathrm{DM}}=0.513151$, $\left({ }^{147} \mathrm{Sm} /{ }^{144} \mathrm{Nd}\right)_{\mathrm{DM}}=0.2136$ (Liew and Hofmann, 1988). The ${ }^{147} \mathrm{Sm} /{ }^{144} \mathrm{Nd}$ value of 0.118 (Jahn and Condie, 1995) for average continental crust was used for the mantle extraction model age $\left(\mathrm{T}_{\mathrm{DM} 2}\right)$ for the source rocks of the magmas.

\section{Results}

\subsection{Zircon $\mathrm{U}-\mathrm{Pb}$ ages}

CL images of representative zircon grains are shown in Fig. 4. The Concordia diagrams and weighted averages of zircon $\mathrm{U}-\mathrm{Pb}$ dating are presented in Fig. 5. The detailed dating results are listed in Appendix A. Because of errors in counting statistics during the analysis, the ${ }^{207} \mathrm{~Pb} /{ }^{206} \mathrm{~Pb}$ ages are more precise for older $\left(>1 \mathrm{Ga}\right.$ ) zircons, whereas the ${ }^{206} \mathrm{~Pb} /{ }^{238} \mathrm{U}$ ages are more precise for younger zircons (Griffin et al., 2004). Therefore, we use the ${ }^{207} \mathrm{~Pb} /{ }^{206} \mathrm{~Pb}$ ages for older zircons (detrital) and ${ }^{206} \mathrm{~Pb} /{ }^{238} \mathrm{U}$ ages for younger zircons in the following discussion. 


\subsubsection{Daguding Fm.}

All zircons of the Daguding Fm are euhedral and typically 100-250 $\mu \mathrm{m}$ long. They exhibit well-developed growth zoning with corresponding high $\mathrm{Th} / \mathrm{U}$ ratios $(>0.4)$, which are typical characteristics of igneous zircons (Belousova et al., 2002). Most of them are relatively transparent and colorless.

Three samples from different depths of drill hole 15701 yield concordant and consistent age results, with 159.4 $\pm 2.4 \mathrm{Ma}(2 \sigma ; \mathrm{n}=14$; MSWD=1.5; Fig. 5a) for 701-840, 158.9 $\pm 1.5 \mathrm{Ma}(2 \sigma ; \mathrm{n}=21$; MSWD=0.59; Fig. 5b) for 701-728, and 158.3 \pm 1.7 Ma $(2 \sigma ; n=27$; MSWD=1.4; Fig. $5 c)$ for $701-700$, respectively. Two samples from drill hole 15150 give similar results, with $155.9 \pm 1.8 \mathrm{Ma}$ $(2 \sigma ; n=22 ; M S W D=1.4$; Fig. 5d) for 150-380 and 155.0 $\pm 2.2 \mathrm{Ma}(2 \sigma ; n=29 ; M S W D=2.4$; Fig. 5e $)$ for 150-245. Sixteen analyses for sample LS45 from the outcrop yield a slightly younger weighted mean ${ }^{206} \mathrm{~Pb} /{ }^{238} \mathrm{U}$ age of $151.6 \pm 4.1 \mathrm{Ma}(2 \sigma ; \mathrm{n}=16$; MSWD=1.06; Fig. $5 \mathrm{f})$. All six samples from the lower, middle and upper parts of the Daguding Fm. suggest an eruption age of the Daguding Fm. of approximately $160 \mathrm{Ma}$.

\subsubsection{Ehuling Fm.}

All zircon grains from the Ehuling Fm. samples are euhedral and 100-200 $\mu \mathrm{m}$ long. They all show clear oscillatory zonations with high $\mathrm{Th} / \mathrm{U}$ ratios of magmatic origin. Three samples from different depths of drill hole 15701 show concordant ages with weighted mean ${ }^{206} \mathrm{~Pb} /{ }^{238} \mathrm{U}$ ages of

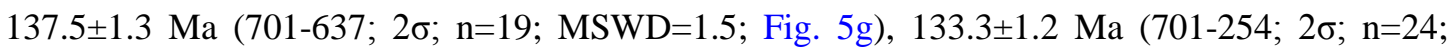
MSWD=1.4; Fig. 5h) and 130.4 $\pm 1.1 \mathrm{Ma}(701-246 ; 2 \sigma, \mathrm{n}=18$; MSWD=0.99; Fig. 5i) for different segments of the Ehuling Fm. Two samples from the outcrop show concordant and consistent ages, with weighted mean ${ }^{206} \mathrm{~Pb} /{ }^{238} \mathrm{U}$ ages of $138.4 \pm 1.3 \mathrm{Ma}$ (LS79; $2 \sigma, \mathrm{n}=17$; MSWD=1.5; Fig. $5 \mathrm{j}$ ) and

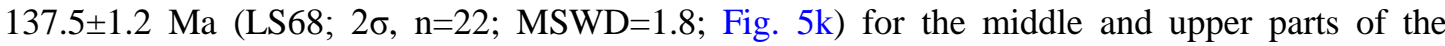
Ehuling Fm., respectively. All of these results demonstrate that the age of the Ehuling Fm. is approximately $130 \mathrm{Ma}$.

\subsection{Zircon Hf isotopic compositions}

A total of eight volcanic rocks were chosen for zircon $\mathrm{Lu}-\mathrm{Hf}$ analyses, and approximately 30 zircon grains were used for each sample. The zircon Hf analyses were performed on the same domains of the same grain as those used for $\mathrm{U}-\mathrm{Pb}$ dating (Fig. 4). The analytical results of the Lu-Hf isotopic compositions are given in Appendix B, and the frequency distribution diagrams of $\varepsilon_{\mathrm{Hf}}(\mathrm{t})$ and $\mathrm{T}_{\mathrm{DM} 2}$ values are presented in Fig. 6 and Fig. 7.

\subsubsection{Daguding Fm.}

The zircon Hf isotopic compositions of two samples, 701-728 and 701-700, from drill hole 15701 are nearly identical. Thirty analyses for 701-728 from the lower part of the Daguding Fm. yield initial ${ }^{176} \mathrm{Hf} /{ }^{177} \mathrm{Hf}$ ratios from 0.282243 to 0.282409 and $\varepsilon_{\mathrm{Hf}}(\mathrm{t})$ values from -15.7 to -9.8 , with a weighted mean of $-12.3 \pm 0.4$ (2SD), corresponding to two-stage model ages $\left(\mathrm{T}_{\mathrm{DM} 2}\right)$ of $1.80-2.16$ 
Ga. Thirty-four zircon grains from 701-700 were used for $\mathrm{Lu}-\mathrm{Hf}$ isotope analyses. Thirty-three of them yield similar initial ${ }^{176} \mathrm{Hf} /{ }^{177} \mathrm{Hf}$ ratios $(0.282216-0.282412)$ and $\varepsilon \mathrm{Hf}(\mathrm{t})$ values (-16.7 to -9.8$)$, with a weighted mean of $-12.6 \pm 0.4$ (2SD), corresponding to a $\mathrm{T}_{\mathrm{DM} 2}$ of 1.80-2.22 Ga. Zircons from samples $150-380$ and 150-245 from drill hole 15150 show similar $\left({ }^{176} \mathrm{Hf} /{ }^{177} \mathrm{Hf}\right)_{\mathrm{i}}$ ratios of $0.282150-0.282395$ and $0.282207-0.282483$, respectively. The $\varepsilon_{\mathrm{Hf}}(\mathrm{t})$ values are -19.1 to -10.4 and -17.1 to -7.3 , with weighted means of $-11.90 \pm 0.44$ ( $2 \mathrm{SD} ; \mathrm{n}=32)$ and $-12.20 \pm 0.58$ (2 SD; $\mathrm{n}=34$ ) and $\mathrm{T}_{\mathrm{DM} 2}$ model ages of 1.83-2.37Ga and 1.64-2.25 Ga, respectively. Twenty-nine grains selected from the crystal tuff (LS45) of the upper part of the Daguding Fm. give initial ${ }^{176} \mathrm{Hf} /{ }^{177} \mathrm{Hf}$ ratios of $0.282324-0.282434$ and $\varepsilon \mathrm{Hf}(\mathrm{t})$ values of -13.0 to -9.2 , with a weighted mean of $-11.41 \pm 0.31$ (2 $\mathrm{SD}$ ), corresponding to $\mathrm{T}_{\mathrm{DM} 2}$ model ages of $1.75-1.99 \mathrm{Ga}$.

All five samples have relatively homogenous zircon $\mathrm{Hf}$ isotope compositions. A total of 159 zircon grains yield initial ${ }^{176} \mathrm{Hf} /{ }^{177} \mathrm{Hf}$ ratios of $0.282017-0.282483$ and $\varepsilon_{\mathrm{Hf}}(\mathrm{t})$ values of -21.9 to -7.3 (Fig. 6b) with a weighted mean of $-12.15 \pm 0.20$, corresponding to a $\mathrm{T}_{\mathrm{DM} 2}$ of $1.64-2.55 \mathrm{Ga}$ (Fig. 7b).

\subsubsection{Ehuling Fm.}

Three samples from different depths of drill hole 15701 were selected for the $\mathrm{Lu}-\mathrm{Hf}$ analyses. Zircon Hf isotope analyses were conducted on thirty-five grains for 701-637 from the lower part of the Ehuling Fm. These analyses yielded initial ${ }^{176} \mathrm{Hf} /{ }^{177} \mathrm{Hf}$ values between 0.282233 and 0.282491 and $\varepsilon_{\mathrm{Hf}}(\mathrm{t})$ values between -16.8 and -7.4 , with a weighted mean of $-10.63 \pm 0.77$ (2 SD) and $\mathrm{T}_{\mathrm{DM} 2}$ ages from 1.63 to $2.21 \mathrm{Ga}$. Concordant and similar zircon $\mathrm{Hf}$ isotopic compositions were obtained for samples 701-254 and 701-246 from the upper parts of the formation. Their $\left({ }^{176} \mathrm{Hf} /{ }^{177} \mathrm{Hf}\right)_{\mathrm{i}}$ ratios are $0.28280-0.282446$ and $0.282159-0.282424$, corresponding to $\varepsilon_{\mathrm{Hf}}(\mathrm{t})$ values of -15.0 to -9.2 and -19.4 to -9.9 , with weighted means of $-11.68 \pm 0.50$ ( $2 \mathrm{SD} ; \mathrm{n}=29)$ and $-12.03 \pm 0.56(2 \mathrm{SD} ; \mathrm{n}=35)$. The $\mathrm{T}_{\mathrm{DM} 2}$ model ages are 1.73-2.10 $\mathrm{Ga}$ and 1.78-2.37 Ga, respectively.

Overall, a total of 99 zircon grains yield initial ${ }^{176} \mathrm{Hf} /{ }^{177} \mathrm{Hf}$ ratios of $0.282159-0.282491$ and $\varepsilon_{\mathrm{Hf}}(\mathrm{t})$ values of -19.4 to -7.4 (Fig. $6 \mathrm{a}$ ), with a weighted mean of $-11.6 \pm 0.4$, corresponding to a $\mathrm{T}_{\mathrm{DM} 2}$ of $1.63-2.37 \mathrm{Ga}$ (Fig. 7a)

\subsection{Major and trace elements}

\subsubsection{Daguding Fm.}

Daguding volcanic rocks have $\mathrm{SiO}_{2}$ contents of 70.9-76.3 wt\%. They all fall in the rhyolite field in TAS diagram (Fig. 8). These rocks are strongly peraluminous with values of the alumina saturation index ASI $\left[=\right.$ molar $\left.\mathrm{Al}_{2} \mathrm{O}_{3} /\left(\mathrm{CaO}+\mathrm{Na}_{2} \mathrm{O}+\mathrm{K}_{2} \mathrm{O}\right)\right]>1.1$ (Table 3; Fig. 9a). These rocks also have high $\mathrm{K}_{2} \mathrm{O}$ contents, with all data plotting in the high-K calc-alkaline and shoshonite fields in a $\mathrm{K}_{2} \mathrm{O}$ vs $\mathrm{SiO}_{2}$ classification diagram (Fig. 9b). These rocks show higher $\mathrm{Mg} \#\left[=\mathrm{Mg} /\left(\mathrm{Mg}+\mathrm{Fe}_{\mathrm{T}}\right)\right]$ than pure crustal melts (Fig. 9c). In a plot of AR (alkalinity ratio) vs $\mathrm{SiO}_{2}$, all samples plot in the alkaline field, except for a few that straddle the boundary with the calc-alkaline field (Fig. 10).

Daguding volcanic rocks have total rare earth element ( $\sum$ REE) contents of 111-227 ppm and exhibit an enrichment of light REE (LREE) relative to heavy REE (HREE) with $\left(\mathrm{La}_{\mathrm{N}} / \mathrm{Yb}_{\mathrm{N}}\right)$ ratios ranging from 7.9 to 28.5 . They also show notable negative Eu anomalies $\left(\mathrm{Eu} / \mathrm{Eu}^{*}=0.32-0.65\right.$; Fig. 
11a). Primitive mantle normalized trace element patterns of the samples show significantly negative $\mathrm{Ba}, \mathrm{Sr}, \mathrm{Nb}, \mathrm{Ta}, \mathrm{Ti}$ and $\mathrm{P}$ anomalies (Fig. 11b). The calculated zircon saturation temperatures are between 700 and $824^{\circ} \mathrm{C}\left(\right.$ mean $=796^{\circ} \mathrm{C}$; Table 3).

\subsubsection{Ehuling Fm.}

Ehuling volcanic rocks have high $\mathrm{SiO}_{2}$ contents in the range of 74.3 to $76.1 \mathrm{wt} \%$. They also fall in the rhyolite field in the TAS diagram (Fig. 8). Most samples are weakly peraluminous (Table 3; Fig. 9a). These volcanic rocks are all alkali-rich with high $\mathrm{K}_{2} \mathrm{O}$ contents (Fig. 9b), and the data are plotted in the alkaline field (Fig. 10). They show higher $\mathrm{FeO} * / \mathrm{MgO}$ ratios and higher alkali contents than the Daguding volcanic rocks (Table 3; Fig. 12b). Most Ehuling volcanic rocks have a low Mg\#, lower than pure crustal melts (Fig. 9c).

Ehuling volcanic rocks have relatively high REE contents (238-515 ppm) with LREE enrichment relative to HREE in all rocks $\left(\mathrm{La}_{\mathrm{N}} / \mathrm{Yb}_{\mathrm{N}}=9.9\right.$ to 31.2$)$. The rocks show significantly negative Eu anomalies $\left(\mathrm{Eu} / \mathrm{Eu}^{*}=0.04-0.0 .09\right.$; Fig. 11a). In the primitive-mantle normalized trace element diagrams, they show significantly negative $\mathrm{Ba}$ and $\mathrm{Sr}$ anomalies (Fig. 11b). These volcanic rocks have high Ga/Al ratios (Fig. 12a) and high HFSE contents (Fig. 12b). The calculated zircon saturation temperatures for these rocks are relatively high $\left(800-867{ }^{\circ} \mathrm{C}\right)$ with a mean temperature of $837^{\circ} \mathrm{C}$ (Table 3).

\section{4. $\mathrm{Sr}-\mathrm{Nd}$ isotopic compositions}

\subsubsection{Daguding Fm.}

Four samples from the Daguding Fm. show a range of ${ }^{87} \mathrm{Rb} /{ }^{86} \mathrm{Sr}$ ratios from 5.13 to 7.66 and ${ }^{87} \mathrm{Sr} /{ }^{86} \mathrm{Sr}$ ratios from 0.720365 to 0.725540 . The ${ }^{147} \mathrm{Sm} /{ }^{144} \mathrm{Nd}$ ratios range from 0.0910 to 0.1386 , and ${ }^{143} \mathrm{Nd} /{ }^{144} \mathrm{Nd}$ ratios vary between 0.512025 and 0.512072 . The initial ${ }^{87} \mathrm{Sr} /{ }^{86} \mathrm{Sr}$ ratios $\left(\mathrm{I}_{\mathrm{Sr}}\right)$ and $\varepsilon_{\mathrm{Nd}}(\mathrm{t})$ values are calculated based on the respective zircon $\mathrm{U}-\mathrm{Pb}$ ages determined in this study. The initial ${ }^{87} \mathrm{Sr} /{ }^{86} \mathrm{Sr}$ ratios cluster between 0.706174 and 0.710594 , and the $\varepsilon_{\mathrm{Nd}}(\mathrm{t})$ values range from -10.2 to -9.5 (Table 3; Fig. 13), with the corresponding $\mathrm{T}_{\mathrm{DM} 2}$ model ages between 1.70 and 1.77 Ga (Table 3).

\subsubsection{Ehuling Fm.}

Ehuling volcanic rocks show similar Nd isotopic compositions, with $\varepsilon_{\mathrm{Nd}}(\mathrm{t})$ values of -9.5 to -8.8 , whereas their $\mathrm{Sr}$ isotopic compositions are more variable, with initial ${ }^{87} \mathrm{Sr} /{ }^{86} \mathrm{Sr}$ ratios from 0.71258 to 0.71919 (Table 3; Fig. 13). The $\mathrm{T}_{\mathrm{DM} 2}$ model ages range from 1.641 to $1.702 \mathrm{Ga}$ (Table $3)$. 


\section{Discussion}

\subsection{Timing of volcanism in northeastern Jiangxi}

The Late Mesozoic volcanic rocks are well developed in the volcanic basins (such as Xiangshan, Shenyuan, and Tianhuashan) in the northeastern Jiangxi Province. According to their eruption cycles, stratigraphic sequences and contact relationships, they can be divided into the Daguding Fm. on the bottom and the Ehuling Fm. on the top. Since the late 1980s, many geochronological studies have been conducted, and a great number of ages have been reported through various methods (Table 4; Fig. 14b). Unfortunately, some of the published results are either of poor quality or are inconsistent with each other, as a result of defective experimental conditions or the violation of the principle of radioactive dating. On the whole, it is obvious that the $\mathrm{K}-\mathrm{Ar}$ and $\mathrm{Ar}-\mathrm{Ar}$ ages are usually much younger than ages obtained by the $\mathrm{Rb}-\mathrm{Sr}$ or $\mathrm{U}-\mathrm{Pb}$ methods. Moreover, some isotopic ages of the Ehuling Fm. are older than those of the underlying Daguding Fm., which is inconsistent with the geology. Because the closure temperatures of $\mathrm{K}-\mathrm{Ar}$ and $\mathrm{Rb}-\mathrm{Sr}$ isotopic systems are low in both single minerals and whole rocks (Dodson, 1973; Ganguly and Tirone, 1999; Harrison and McDougall, 1980; Villa, 1998), they can be easily disturbed by subsequent extensive hydrothermal alteration or other thermo-tectonic events. In contrast, the lowest closure temperature of the $\mathrm{U}-\mathrm{Pb}$ isotope system in zircon can reach $800{ }^{\circ} \mathrm{C}$ (Lee et al., 1997; Cherniak and Watson, 2001), which is higher than the temperature of felsic magma (Carmichael et al., 1974). Therefore, the U-Pb isotope system in zircon could stay stable and closed in the geothermal event since the magmatic crystallization. In addition, the zircon U-Pb dating method has much smaller systematic error than the $\mathrm{K}-\mathrm{Ar}$ and $\mathrm{Rb}-\mathrm{Sr}$ methods. Therefore, the zircon $\mathrm{U}-\mathrm{Pb}$ dating method would be the most appropriate dating method for multi-stage magmatic activities, and it has been widely used (e.g., Condie et al., 2009; Li et al., 2008; Li et al., 2011; Liu et al., 2012; Wan et al., 2006; Ye et al., 2007; Zhu et al., 2013). To mitigate the effect of dating methods, the following discussions based primarily on the zircon U-Pb data. However, except for the results based on $\mathrm{Rb}-\mathrm{Sr}$ and $\mathrm{K}-\mathrm{Ar}$ methods, controversies about the eruption ages of these volcanic rocks remain.

First, different researchers have obtained different ages on the same stratum in the same basin, when even using the same methods. Previous geologists have suggested that the volcanic-intrusive complex in the Xiangshan area was formed from the middle Jurassic to the early Cretaceous (Fang et al., 1982; Li et al., 1989; Liu, 1985). However, recent precise zircon U-Pb dating results have shown that both the Daguding and Ehuling Fms. at the Xiangshan basin were formed in the early Cretaceous (Fan et al., 2005; Yang et al., 2011; Yang and Jiang, 2013; Fig. 14b). In the Tianhuashan basin, Meng et al. (2012) reported that the crystal tuff from the Ehuling Fm. formed at ca. 157.2-158.2 Ma based on the U-Pb dating of zircon by the SHRIMP method, and they suggested that both the Ehuling and Daguding Fms. were formed in the Late Jurassic. This viewpoint received support from later published data (Qiu et al., 2013; Xu et al., 2013). Nevertheless, a recent geochronological investigation indicated that both the Ehuling and Daguding Fms.' volcanic rocks likely formed in 144-137 Ma, the Early Cretaceous (Su et al., 2014). Considering the continuous debate on the ages of these volcanic rocks, we preferred to collect the samples from well-logged drill cores and then systematically measure the ages of the 
volcanic sequences in the Tianhuashan basin by the LA-ICP-MS U-Pb zircon dating method. Our results suggest that the Daguding Fm. was formed in the Late Jurassic (150-160 Ma), whereas the Ehuling Fm. was formed in the Early Cretaceous (130-140 Ma; Fig. 14a). The confirmation of two-stage eruptions is not only consistent with most of the published ages and the distributions of their respective stratum (Fig. 14b) but also accords with the two corresponding stages of intrusive rocks (Meng et al., 2012; Qiu et al., 2013; Su et al., 2014; Wang et al., 2013; Zuo et al., 2010). Furthermore, the field contact relations that the Late Jurassic granite porphyry intruded into the volcanic strata demonstrate that the Daguding Fm. formed in the Late Jurassic. Those published Late Jurassic ages of the Ehuling Fm. (Meng et al., 2012; Xu et al., 2013) may be due to an improper sampling; i.e., the measured crystal tuff samples were actually from the Daguding Fm. rather than the Ehuling Fm.

Second, the geological framework of the volcanic sequences among the basins was inconsistent. As discussed above, the volcanic sequences in the Tianhuashan basin formed in the Late Jurassic and Early Cretaceous, respectively. By comparison, all geochronological results consistently show that both the Ehuling Fm. and the Daguding Fm. in the Xiangshan and Shengyuan basins were formed in the Early Cretaceous (Fig. 14b; Wu et al., 2011; Yang et al., 2011; Yang et al., 2013; Zhang, 2000; Zhang and Li, 2007). Two situations may be responsible for the different dating results of the same named volcanic strata between different volcanic basins: (1) The Late Jurassic volcanic rocks in the Xiangshan and Shengyuan basins have not yet been found, and (2) the volcanic sequences between the Gan-Hang tectonic belt and the northern Wuyi Mountain volcanic belt are different, as are their corresponding ages. Therefore, more specific and systematic geochronological work is crucial to establish the chronology framework of magmatism and volcanism in the Xiangshan basin and the other volcanic basins in northeastern Jiangxi Province. The Daguding Fm. and Ehuling Fm. should be reexamined in the area.

\subsection{Petrogenesis of the late Jurassic Daguding volcanic rocks}

\subsubsection{Genetic type}

The Daguding volcanic rocks are strongly peraluminous with an ASI >1.1. They fall into the cordierite-muscovite field in the ACF diagram (Fig. 15, Chappell and White, 1992) and have relatively low $\mathrm{Na}_{2} \mathrm{O}$ and $\mathrm{CaO}$ contents, which indicate they belong to S-type volcanics (Chappell and White, 1992; Chappell and White, 2001). Moreover, Daguding volcanic rocks also show a slight decrease in $\mathrm{Y}$ and $\mathrm{Th}$ as $\mathrm{Rb}$ increases, typical of the S-type granite evolution trend. Most peraluminous granitoids are divided into two distinct groups: muscovite-bearing peraluminous granitoids (MPGs) and cordierite-bearing peraluminous granitoids (CPGs), based on the mineral and rock associations and the variation of their peraluminosity during differentiation (Barbarin, 1996). As suggested by Barbarin (1996), MPGs, which are relatively poor in biotite and contain large primary muscovite, are produced primarily in orogenic zones affected by major crustal shear or overthrust structures, through the "wet" anatexis of crustal rocks and the crystal fractionation of magmas. Nevertheless, the CPGs, which contain cordierite and accessory aluminum silicates, are suggested to be produced through the 'dry' anatexis of crustal rocks enhanced by underplating or the injection of hot mantle-derived magmas (Barbarin, 1996). The model emphasizes the 
importance of the condition of crustal partial melting in the genesis of the two types of peraluminous granitoids.

Daguding volcanic rocks contain biotite (Fig. 3b) and show relatively high magmatic temperatures (770-837 ${ }^{\circ} \mathrm{C}$; Table 3), which are similar to Tongshanling granite in the southern Hunan province, which Jiang et al. (2009) attributed to CPGs. Thus, these volcanic rocks should resemble the counterparts of CPGs.

\subsubsection{Petrogenetic model}

As mentioned above, Daguding volcanic rocks, which resemble the counterparts of CPGs, were likely derived from the anatexis of crustal rocks induced by the underplating or injection of hot mantle-derived magmas (Barbarin, 1996). These volcanics are strongly peraluminous, suggesting that primarily metasedimentary rocks were involved in partial melting. Their radiogenic ${ }^{87} \mathrm{Sr} /{ }^{86} \mathrm{Sr}(0.70617-0.71059)$, unradiogenic ${ }^{143} \mathrm{Nd} /{ }^{144} \mathrm{Nd}$ ratios $\left(\varepsilon_{\mathrm{Nd}}(\mathrm{t})=-10.2\right.$ to -9.2$)$ and negative initial $\varepsilon_{\mathrm{Hf}}(\mathrm{t})$ values $(-21.9$ to -7.3$)$ also indicate that the source rocks are primarily metasedimentary rocks rather than metaigneous rocks. The Paleoproterozoic $\mathrm{T}_{\mathrm{DM} 2}$ ages of both $\mathrm{Nd}$ and Hf isotopes require a Paleoproterozoic source rock (Fig. 13). The Paleoproterozoic basement in this region, the Mayuan Group, is composed of biotite plagioclase granulite and biotite gneiss. Experiments have demonstrated that the partial melting of biotite gneiss and quartz amphibolite from 3 to $15 \mathrm{kba}$ could generate high Mg\# melts such as Daguding (Patino Douce and Beard, 1995). These volcanic rocks share the same Nd isotopic compositions as the Mayuan Group (Chen and Jahn, 1998). Their Hf isotopic compositions also fall roughly in the Hf isotope evolution trends of the known Proterozoic rocks (Fig. 16). Thus, these rocks were likely produced by the remelting of these ancient crustal rocks.

Daguding volcanic rocks have a relatively low HREE ( $\mathrm{Yb}=1.0-2.2 \mathrm{ppm})$ and $\mathrm{Y}$ (15.6-23.7 ppm) contents and exhibit relatively steep HREE patterns $\left(\mathrm{Gd}_{N} / \mathrm{Yb}_{\mathrm{N}}=1.7-3.0\right.$; Fig. 11a), which suggests the garnet rather than amphibole is the main residual assemblage in the source. They also have a relatively low Sr (44-129 ppm) and show obviously negative Eu anomalies (Fig. 11a), which require that the source region be within the stability field of plagioclase and/or K-feldspar. In addition, volcanic rocks have very high Ba concentrations (363-904 ppm, Table 4), indicating that plagioclase rather than K-feldspar is the main residual assemblage in the source. Experiments indicate that during the dehydration-melting of metasedimentary (biotite gneiss), plagioclase keeps stable when the pressure is $<15 \mathrm{kbar}$, whereas the garnet remains in residual phases at pressures $>12.5$ kbar (Patino Douce and Beard, 1995). The fact that both garnet and plagioclase remain as a residual assemblage implies that the source region of the Daguding volcanic rocks is relatively deep ( $\sim 40-50 \mathrm{~km}$, corresponding to $12.5-15 \mathrm{kbar})$.

\subsection{Petrogenesis of the early Cretaceous Ehuling volcanic rocks}

\subsubsection{Genetic type}

The geochemical characteristics of the Ehuling volcanic rocks suggest an A-type affinity. These volcanic rocks are enriched in alkalis (Figs. 10), REE (except for Eu, Fig. 11a) and HFSE 
but are depleted in $\mathrm{Ba}$ and $\mathrm{Sr}$ (Fig. 11b). They also exhibit high Ga/Al ratios (Fig. 12a). These features of A-type granites have been recognized by many researchers (Collins et al., 1982; Eby, 1992; Whalen et al., 1987). Chappell and White (1992) noted that highly fractionated felsic I- and S-type granites can have major and trace element compositions overlapping those of typical A-type granites. However, A-type granites have much higher amounts of HFSE than I- and S-type granites. The fractionated I- and S-type granites evolve towards the A-type in terms of $\mathrm{Nb}$ and $\mathrm{Ga}$, relative to the unfractionated granites, but the concomitant changes lead to higher $\mathrm{Rb}$ and $\mathrm{U}$ and lower $\mathrm{Ba}$ and $\mathrm{Sr}$, which are distinct from A-type granites. Compared with A-type granites, fractionated S-type granites contain more $\mathrm{Al}_{2} \mathrm{O}_{3}$ and $\mathrm{P}_{2} \mathrm{O}_{5}$. Furthermore, fractionated felsic granites tend to have HFSE trends that display a negative correlation with increasing crystal fractionation (King et al., 1997). In the discrimination diagram of $\mathrm{FeO} * \mathrm{MgO}$ vs. $(\mathrm{Zr}+\mathrm{Nb}+\mathrm{Y}+\mathrm{Ce}$; Fig. 12b; Whalen et al., 1987), they are plotted in the A-type granite field rather than fractionated granites. They also fall in the field of A-type granites in the $\mathrm{Zr}$ vs. $10000 * \mathrm{Ga} / \mathrm{Al}$ diagram (Fig. 12a). The High $\mathrm{Rb} / \mathrm{Nb}$ and $\mathrm{Y} / \mathrm{Nb}$ ratios of these rocks further indicate that the Ehuling volcanic rocks belong to the $\mathrm{A}_{2}$ group (Fig. 12c and d), which indicate these volcanic rocks might have derived from continental crust or underplated crust that has been through a cycle of continent-continent collision or island-arc magmatism (Eby, 1992). The calculated zircon saturation temperatures $\left(\mathrm{T}_{\mathrm{Zr}}\right.$; Watson and Harrison, 1983) of the Ehuling volcanic rocks are $826-867{ }^{\circ} \mathrm{C}$ (average $838^{\circ} \mathrm{C}$, Table 3), which suggest that these volcanic rocks were formed at a high temperature.

\subsubsection{Petrogenetic model}

Various petrogenetic schemes have been proposed for the origin of A-type granitic and volcanic rocks, including extensive fractional crystallization from mantle-derived basaltic magmas (e.g., Anderson et al., 2003; Smith et al., 1999; Turner et al., 1992) and partial melting at elevated temperatures of specific continental crustal protoliths that have been depleted in water by the extraction of hydrous felsic magma (e.g., Collins et al., 1982; Creaser et al., 1991; Eby, 1992; Whalen et al., 1987). Additionally, Patino Douce (1997) emphasized the important role of the physical parameters of partial melting over the nature of the sources in engendering A-type melts.

It is worth noting that a number of Early Cretaceous A-type granites have been identified along the Gan-Hang Belt, including the Xiangshan volcanic-intrusive complex (135-137 Ma, Yang et al., 2011), Yangmeiwan granite (135 Ma, Yang et al., 2012), Daqiaowu granitic porphyry (133-136 Ma, Yang et al., 2012), Tongshan granite (129 Ma, Jiang et al., 2011), Baijuhuajian granite (126 Ma, Wong et al., 2009) and Damaoshan granite (122-126 Ma, Jiang et al., 2011). There are two distinct views on the petrogenesis of these A-type granitic rocks. Wong et al. (2009) suggested that the Baijuhuajian magma was derived originally from asthenospheric mantle and experienced extensive crystal fractionation and minor mixing with old crustal components. Others have preferred a formation model by the partial melting of ancient crustal protoliths followed by fractional crystallization (Jiang et al., 2011; Yang et al., 2011; Yang et al., 2012).

All Ehuling volcanic rocks are characterized by clearly negative and uniform $\varepsilon_{\mathrm{Nd}}(\mathrm{t})$ values of -9.5 to -8.8 and high initial ${ }^{87} \mathrm{Sr} /{ }^{86} \mathrm{Sr}$ ratios of $0.71258-0.71919$, which exclude the possibility that these A-type volcanic rocks were formed by extensive fractional crystallization from coeval mafic magmas. Instead, they show a close relationship to Proterozoic metamorphic basement rocks in 
terms of Sr-Nd isotopic compositions (Fig. 13), indicating that they were most likely derived from these ancient crustal rocks. This finding is consistent with the petrogenesis of the $\mathrm{A}_{2}$ group proposed by former geologists (Eby, 1992). These volcanic rocks are primarily slightly peraluminous (Fig. 9a), suggesting that metaigneous rocks and metasedimentary rocks melted to form these magmas. This view is further supported by the rocks' $\mathrm{Sr}-\mathrm{Nd}$ isotopic compositions. Compared to metasedimentary rocks at the age of eruption, Ehuling volcanic rocks have much lower initial ${ }^{87} \mathrm{Sr} /{ }^{86} \mathrm{Sr}$ ratios and slightly higher $\varepsilon_{\mathrm{Nd}}(\mathrm{t})$ values (Fig. 13), which indicate that a small proportion of metaigneous rocks was likely involved in partial melting. Furthermore, these volcanic rocks had Paleoproterozoic $\mathrm{T}_{\mathrm{DM} 2}$ ages of both $\mathrm{Nd}$ and $\mathrm{Hf}$ isotopes, which suggests a major Paleoproterozoic crustal source. Their Hf isotopic compositions are also roughly consistent with the Hf isotope evolution trends of the Cathaysia crustal basement (Fig. 16), attesting to their crustal sources.

Ehuling volcanic rocks show relatively steep HREE patterns (Fig. 11a), a depletion of $\mathrm{Sr}$ and $\mathrm{Ba}$ (Fig. 11b) and significantly negative Eu anomalies (Fig. 11a), therefore requiring the melting of a source rock within the stability field of plagioclase and K-feldspar. Most of these volcanic rocks have a very low $\mathrm{Mg \# ,} \mathrm{lower} \mathrm{than} \mathrm{that} \mathrm{of} \mathrm{pure} \mathrm{crustal} \mathrm{melts,} \mathrm{except} \mathrm{for} \mathrm{four} \mathrm{samples}$ (701-251, 701-258,701-286 and 701-662), which show an Mg\# consistent with pure crustal partial melts (Fig. 9c). Samples 701-258, which also have relatively high Eu, Sr and Ba contents, were regarded as the initial crustal partial melts. Other samples show a lower Mg\# than pure crustal melts (Fig. 9c), suggesting that the magmas might have undergone the subsequent fractionation of mafic minerals, such as biotite, after partial melting. Element variations indicate that plagioclase and K-feldspar fractionation is also required (Fig. 17).

\subsection{Tectonic evolution of Southeast China during the late Mesozoic}

\subsubsection{Late Jurassic (approximately $160 \mathrm{Ma}$ )}

The extensive magmatism and associated numerous mineral deposits in South China have attracted considerable attention from geologists for decades. However, there is an ongoing debate concerning the tectonic settings and geodynamics responsible for the extensive late Mesozoic magmatism (Charvet et al., 1994; Chen et al., 2008; Gilder et al., 1996; Jiang et al., 2009; Jiang et al., 2011; John et al., 1990; Lapierre et al., 1997; Li et al., 2003; Li et al., 2007; Li and Li, 2007; Li et al., 2014).

$\mathrm{Li}$ et al. (2004) proposed an intraplate rifting and extension environment for the genesis of Jurassic alkaline basalts and "intraplate-type" syenites in the interior of South China, and the secular variations in rock types and geochemical and isotopic characteristics were interpreted as a response to the lithosphere's extension and thinning. The occurrence of coeval A-type felsic and mafic magmatism in southern Jiangxi also provides support for an extension-to-rifting regime prevalent in much of the southeast China interior during the Middle to Late Jurassic times (He et al., 2010; Li et al., 2003).

Chen et al. (2008) investigated two Mesozoic basalt successions in South China and found that the east-west trending basalts extending from the Cathaysia Interior to the Cathaysia Folded Belt, which decreased in age from 175 to $98 \mathrm{Ma}$ in an eastward direction, were derived from the 
lithosphere-modified OIB-like asthenosphere. It was distinctly different from the Southeast Coast Magmatic Belt, which had been modified by the paleo-Pacific subduction system. These results indicated that the Jurassic mantle beneath the Cathaysia Interior and the Cathaysia Folded Belt was rather homogeneous and undisturbed by the subduction system before the Late Cretaceous, which is in accordance with the occurrence of two Early Cretaceous gabbroic intrusions in the coastal area of Fujian Province (Zhao et al., 2007). Hence, Jurassic magmatism in South China is explained as being due primarily to post-Indosinian continental extension and post-orogenic extension accompanied by mafic underplating, which may have been the cause of extensive Jurassic granitic magmatism in South China (Chen et al., 2008). However, the unconformity between strata does not support the above views. For example, the Early Cretaceous Dongkeng volcanic basins in southern Jiangxi unconformably overlie the pre-Jurassic strata (Chen et al., 2007) and the Early Cretaceous Nanyuan formation unconformably rests on the Early Jurassic Lishan Formation (Xing et al., 2008). Meanwhile, angular unconformity also widely existed in the northeast of the Gan-Hang Belt, with most of the unconformity caused by folding ( $\mathrm{Li}$ et al., 2013). Moreover, the two Jurassic NE-trending A-type granite belts are inconsistent with the east-west linear array expected from the post-collisional model (Jiang et al., 2015).

Overall, most researchers have accepted that South China was influenced by the subduction of the Paleo-Pacific plate during the late Mesozoic. Unfortunately, the style of subduction is still debatable. Lapierre et al. (1997) investigated the high-K calc-alkaline volcanic and plutonic rocks in the coastal region and suggested that a normal subduction continued from the Late Jurassic to the Early Cretaceous, but this subduction-related model fails to explain the $>1000-\mathrm{km}$-wide magmatic belt in South China. Zhou and Li (2000) demonstrated that the slab dip angle of Paleo-Pacific plate subduction underneath Southeastern China increased from a very low angle to a medium angle from the Early Jurassic to the Late Cretaceous, which they interpreted as accounting for the exceptionally wide magmatic arc and the migration of magmatic activity oceanward to the southeast. Unfortunately, this modified subduction model does not explain the intraplate feature of the Jurassic A-type granites and mafic intrusive and volcanic rocks in the interior of South China (Chen et al., 2008; Jiang et al., 2009; Jiang et al., 2015; Li et al., 2003; Li et al., 2004; $\mathrm{Li}$ et al., 2007). $\mathrm{Li}$ and $\mathrm{Li}$ (2007) proposed a model of flat-slab subduction on the basis of structural, geochronological and sedimentary facies observations. This model suggests that the subducted Paleo-Pacific plate reached the Yangtze Block by the Late Triassic (ca. $210 \mathrm{Ma}$ ), and the Jurassic magmatism was ascribed to the break-off and foundering event of the subducting/subducted flat slab in the Early Jurassic ( $\mathrm{Li}$ et al., 2007; $\mathrm{Li}$ and $\mathrm{Li}, 2007$ ). Geochronological and geochemical results from Mesozoic basalts and Jiufeng pluton in the South China Block also support the flat-slab subduction model (Huang et al., 2015; Meng et al., 2012). However, this model is inconsistent with the observations of He et al. (2010). First, slab break-off should generate contemporaneous mafic magmas with arc and non-arc geochemical signatures (Cvetković et al., 2004; Whalen et al., 2006), but all of the Jurassic and Early Cretaceous gabbros and syenites and A-type granites are of within-plate origin without subduction-related magmatism (He et al., 2010; Jiang et al., 2015; Li et al., 2003; Li et al., 2013). Second, there are no known Jurassic adakitic rocks within South China that would be expected as a result of broken slab melting (Chen et al., 2008; He et al., 2010). Finally, Wang et al. (2007) argued that the Indosinian magmatism was related to collision between Indochina and South China rather than the 
Paleo-Pacific subduction system, and the tectonic elements also indicated an N-S compression as a result of the northward collision of the Indochina Block in the Triassic (Zhang et al., 2009), which is inconsistent with the westward subduction of the Pacific plate initiated at $250 \mathrm{Ma}$. More recently, a large amount of Early Jurassic A-type and mafic magmatism has been recognized in the southern Jiangxi and western Fujian provinces (He et al., 2010; Jiang et al., 2015; Li et al., 2003); their time-space distribution and geochemical features suggest a continental arc setting (Jiang et al., 2015). This finding is also supported by coeval shoshonitic rocks (Jiang et al., 2009), which typically occur in destructive plate margin settings and extensional environments (Eklund et al., 1998; Morrison, 1980; Müller et al., 1992; Rogers et al., 1998; Turner et al., 1996). Integrating new and previous data, Jiang et al. (2015) proposed a repeated slab advance-retreat model for the late Mesozoic magmatic evolution of southeast China.

The consensus of all models is that the South China Block has been under extensional environments since the Jurassic. The long-time extension led to the decompressional melting of underlying mantle sources to form abundant Jurassic basaltic, syenitic and $\mathrm{A}_{2}$-type granitic rocks in the Nanling region (He et al., 2010; Jiang et al., 2006; Jiang et al., 2009; Jiang et al., 2015; Li et al., 2003; Li et al., 2004). In particular, the Late Jurassic Daoxian basalts show significant arc-like geochemical features, a finding that is compatible with the continental arc-rifting environment, as the $\mathrm{A}_{2}$-type granites suggested (Jiang et al., 2009; Jiang et al., 2015). As discussed earlier, two stages of the Late Mesozoic volcanism in the Tianhuashan basin have been successfully identified, Daguding Fm. in the Late Jurassic and Ehuling Fm. in the Early Cretaceous, respectively. The temporal and spatial distribution of these volcanic rocks may provide an opportunity to verify the late Mesozoic tectonic evolution of South China. Daguding potassium-rich calc-alkali rhyolitic volcanic rocks are relatively enriched in LILE and depleted in HFSE with negative $\mathrm{Nb}$, Ta and Ti anomalies, which shows the affinity of the volcanic rocks related to subduction (Thirlwall et al., 1994). Moreover, in the discrimination diagrams (Fig. 18, Pearce et al., 1984), Daguding volcanic rocks fall in the VAG field, similarly to the contemporaneous granitoids in the WZG region (Zhejiang, Jiangxi, and Anhui provinces), which have been interpreted as having formed in a volcanic arc related to the subduction of the Izanagi plate (Li et al., 2013). Thus, the Late Jurassic magmatism in the northeastern Jiangxi Province likely happened in a continental arc environment related to the subduction of the paleo-Pacific plate.

\subsubsection{Early Cretaceous (approximately $130 \mathrm{Ma}$ )}

Although the tectonic regime accounting for the Jurassic (early Yanshanian) magmatism inland is enigmatic and controversial, there is a general consensus that the Cretaceous (late Yanshanian) magmatism along the coastal areas occurred in an active continental margin due to the subduction of the Paleo-Pacific oceanic plate.

As mentioned earlier, in addition to Ehuling volcanic rocks, a number of Early Cretaceous $\mathrm{A}_{2}$-type granites have been identified along the Gan-Hang Belt and in the WZG region (Jiang et al., 2011; Li et al., 2013; Wong et al., 2009; Yang et al., 2012; Zhou et al., 2013). It has long been recognized that A-type magmas are mostly emplaced in extensional tectonic settings, including continental arc, back-arc extension, post-collisional extension and within-plate settings (Eby, 1992; Förster et al., 1997; Jiang et al., 2009; Jiang et al., 2011; Smith et al., 1999; Whalen et al., 1996). Eby (1992) suggested that the $A_{1}$ group seemed to be restricted to hotspots, plumes or continental 
rift zones located in anorogenic settings, whereas the $\mathrm{A}_{2}$ group granitoids might be associated with the waning stages of arc magmatism. In addition, all $\mathrm{A}_{2}$-type granitoids show a WPG affinity in the tectonic environment discrimination diagram (Fig. 18, Pearce et al., 1984), which suggests an extensional geological setting. In consideration of the regional coeval intermediate-mafic rocks and the geological characteristics (Deng et al., 2014; Jiang et al., 2006; Jiang et al., 2009; Jiang et al., 2011; Li et al., 2013; Yang et al., 2011; Yang et al., 2012; Zhao et al., 2012), we favor the viewpoint that Ehuling volcanic rocks might have erupted at the terminal stage of continental arc, most likely at the beginning of the extension of back-arc or of the rifting of continental arc. It is noteworthy that the timing of the extension along the Gan-Hang Belt in the Cretaceous was as early as ca. $139 \mathrm{Ma}$ in the Tianhuashan basin, which was later than the one that occurred along the south part of the Shi-Hang Zone (He et al., 2010; Jiang et al., 2009; Li et al., 2003). Integrating the previously published data, it can also be concluded that the extension along the Gan-Hang Belt lasted from 139 Ma to $122 \mathrm{Ma}$ in the Early Cretaceous (Jiang et al., 2011; Yang et al., 2011; Yang et al., 2012).

In summary, the Late Jurassic Daguding volcanic rocks in the northeastern Jiangxi Province formed in a continental arc environment related to the subduction of the Paleo-Pacific plate during the Late Jurassic ( 160 Ma; Fig. 19a). Since the Early Cretaceous ( 130 Ma), an intra-arc rift has formed or back-arc extension has developed along the Gan-Hang Belt (or Gan-Hang rift) as a consequence of slab rollback. This finding is further supported by recent geochronological and geochemical studies that have indicated that the regional extension gradually migrated from the inland area to the coastal area due to the progressive slab rollback of the Paleo-Pacific plate (Deng et al., 2014; Jiang et al., 2009; Jiang et al., 2011; Su et al., 2014; Wong et al., 2009; Yang et al., 2012). With ongoing extension during slab rollback, the crust and lithospheric mantle became progressively thinner. The upwelling of the asthenosphere and the underplating of mantle-derived magmas triggered crustal rocks to partially melt and generate hot magmas. The partial melting of granulitized Proterozoic metamorphic basement rocks (including both parametamorphic and orthometamorphic rocks) in the thinned crust close to the Gan-Hang Belt formed Ehuling A-type magmas (Fig. 19b).

\section{Conclusions}

1) LA-ICP-MS zircon U-Pb dating indicates that the Late Mesozoic volcanism in the Tianhuashan basin of the northeastern Jiangxi Province is episodic. The early volcanism took place in the Late Jurassic ( 160 Ma), forming the Daguding Fm., and the late volcanism erupted in the Early Cretaceous ( $130 \mathrm{Ma})$, forming the Ehuling Fm.

2) Daguding volcanic rocks show an association of rhyolite and have high $\mathrm{K}_{2} \mathrm{O}$ contents. They are also strongly peraluminous and belong to the S-type. All rocks are characterized by negative $\varepsilon N d(t)$ and $\varepsilon \mathrm{Hf}(\mathrm{t})$ values and Paleoproterozoic $\mathrm{T}_{\mathrm{DM} 2}$ ages, implying that they were most likely derived from the Paleoproterozoic metasedimentary basement.

3) Ehuling volcanic rocks are primarily weakly peraluminous and show an $A_{2}$ subtype affinity. Geochemical and isotopic data suggest that they were formed by the partial melting of the granulitized Paleoproterozoic metamorphic basement (including parametamorphic and orthometamorphic rocks) at a high temperature and followed by the fractional crystallization of biotite, plagioclase and K-feldspar. 
4) Detailed geochronological and geochemical data for the Late Jurassic to Early Cretaceous volcanic rocks in the northeastern Jiangxi Province imply that during the Late Jurassic, SE China on the Gan-Hang Belt was a continental arc related to the subduction of the Paleo-Pacific plate. Since the beginning of Early Cretaceous, an intra-arc rift has formed along the Gan-Hang Belt as a consequence of slab rollback. It can also be concluded that the extension in the Gan-Hang Belt began later than that in the southwestern part of the Shi-Hang Zone in South China and lasted from $139 \mathrm{Ma}$ to $122 \mathrm{Ma}$.

\section{Acknowledgements}

The authors want to thank Tao Yang, Wei Pu, Qian Liu and Bin Wu with geochemical and isotopic analyses. Prof. Yunpeng Dong and three reviewers provided valuable comments and suggestion which helped to improve this manuscript significantly. This work was supported by a Major State Basic Research 973 Program of China (2012CB416706) and a project from the China National Science Foundation (No. 41072055).

\section{References:}

Andersen, T., 2002. Correction of common lead in $\mathrm{U}-\mathrm{Pb}$ analyses that do not report ${ }^{204} \mathrm{~Pb}$. Chemical Geology 192, 59-79.

Anderson, I.C., Frost, C.D., Frost, B.R., 2003. Petrogenesis of the Red Mountain pluton, Laramie anorthosite complex, Wyoming: implications for the origin of A-type granite. Precambrian Research 124, 243-267.

Barbarin, B., 1996. Genesis of the two main types of peraluminous granitoids. Geology 24, 295-298.

Belousova, E., Griffin, W., O'Reilly, S., Fisher, N., 2002. Igneous zircon: trace element composition as an indicator of source rock type. Contributions to Mineralogy and Petrology 143, 602-622.

Black, L.P., Gulson, B.L., 1978. The age of the mud tank carbonatite, strangways range, northern territory. BMR Journal of Australian Geology and Geophysics 3, 227-232.

Bouvier, A., Vervoort, J.D., Patchett, P.J., 2008. The Lu - Hf and Sm- Nd isotopic composition of CHUR: constraints from unequilibrated chondrites and implications for the bulk composition of terrestrial planets. Earth and Planetary Science Letters 273, 48-57.

Boynton, W.V., 1984. Cosmochemistry of the rare earth elements: meteorite studies.

Carmichael, I.S., Turner, F.J., Verhoogen, J., 1974. Igneous petrology. McGraw-Hill New York.

Chappell, B.W., White, A., 1992. I-and S-type granites in the Lachlan Fold Belt. Transactions of the Royal Society of Edinburgh: Earth Sciences 83, 1-26.

Chappell, B.W., White, A.J.R., 2001. Two contrasting granite types: 25 years later. Australian Journal of Earth Sciences 48, 489-499.

Charvet, J., Lapierre, H., Yu, Y., 1994. Geodynamic significance of the Mesozoic volcanism of southeastern China. Journal of Southeast Asian Earth Sciences 9, 387-396.

Chen, C.H., Lee, C.Y., Shinjo, R., 2008. Was there Jurassic paleo-Pacific subduction in South China?: Constraints from 40Ar/39Ar dating, elemental and $\mathrm{Sr}-\mathrm{Nd}-\mathrm{Pb}$ isotopic geochemistry of the Mesozoic basalts. Lithos 106, 83-92.

Chen, J.F., Jahn, B., 1998. Crustal evolution of southeastern China: $\mathrm{Nd}$ and $\mathrm{Sr}$ isotopic evidence. 
Tectonophysics 284, 101-133.

Chen, R., Xing, G.F., Yang, Z.L., Zhou, Y.Z., Yu, M.G., Li, L.M., 2007. Early Jurassic zircon SHRIMP $\mathrm{U}-\mathrm{Pb}$ age of the dacitic volcanic rocks in the southeastern Zhejiang Province, determined firstly and its geological significances. Geological Review 53, 31-35(in Chinese with English abstract).

Cherniak, D.J., Watson, E.B., 2001. Pb diffusion in zircon. Chemical Geology 172, 5-24.

Collins, W.J., Beams, S.D., White, A., Chappell, B.W., 1982. Nature and origin of A-type granites with particular reference to southeastern Australia. Contributions to Mineralogy and Petrology 80, 189-200.

Condie, K.C., Belousova, E., Griffin, W.L., Sircombe, K.N., 2009. Granitoid events in space and time: Constraints from igneous and detrital zircon age spectra. Gondwana Research 15, 228-242.

Creaser, R.A., Price, R.C., Wormald, R.J., 1991. A-type granites revisited: assessment of a residual-source model. Geology 19, 163-166.

Cvetković, V., Prelević, D., Downes, H., Jovanović, M., Vaselli, O., Pécskay, Z., 2004. Origin and geodynamic significance of Tertiary postcollisional basaltic magmatism in Serbia (central Balkan Peninsula). Lithos 73, 161-186.

Deng, Z.B., Liu, S.W., Zhang, L.F., Wang, Z.Q., Wang, W., Yang, P.T., Luo, P., Guo, B.R., 2014. Geochemistry, zircon $\mathrm{U}-\mathrm{Pb}$ and $\mathrm{Lu}-\mathrm{Hf}$ isotopes of an Early Cretaceous intrusive suite in northeastern Jiangxi Province, South China Block: Implications for petrogenesis, crust/mantle interactions and geodynamic processes. Lithos 200-201, 334-354.

Dodson, M.H., 1973. Closure temperature in cooling geochronological and petrological systems. Contributions to Mineralogy and Petrology 40, 259-274.

Eby, G.N., 1992. Chemical subdivision of the A-type granitoids: petrogenetic and tectonic implications. Geology 20, 641-644.

Eklund, O., Konopelko, D., Rutanen, H., Fr Jd, S., Shebanov, A.D., 1998. 1.8 Ga Svecofennian post-collisional shoshonitic magmatism in the Fennoscandian shield. Lithos 45, 87-108.

Fan, H.H., Wang, D.Z., Shen, W.Z., Liu, C.S., Wang, X., Ling, H.F., 2005. Formation age of the intermediate- basic dikes and volcanic- intrusive complex in Xiangshan, Jiangxi Province. Geological Review 51, 86-91(in Chinese with English abstract).

Fang, X.H., Hou, W.Y., Wan, G.L., 1982. Petrographic studies of the volcanic complex in the Xiangshan Caldera. Acta Petrologica Mineralogica et Analytica 1, 2-9(in Chinese with English abstract).

Förster, H.J., Tischendorf, G., Trumbull, R.B., 1997. An evaluation of the Rb vs. (Y+Nb) discrimination diagram to infer tectonic setting of silicic igneous rocks. Lithos 40, 261-293.

Ganguly, J., Tirone, M., 1999. Diffusion closure temperature and age of a mineral with arbitrary extent of diffusion: theoretical formulation and applications. Earth and Planetary Science Letters 170, 131-140.

Gao, J.F., Lu, J.J., Lai, M.Y., Pu, W., 2003. Analysis of trace elements in rock samples using HR-ICPMS. Journal of Nanjing University (Natural Sciences) 39, 844-850(in Chinese with English abstract).

Gilder, S.A., Gill, J., Coe, R.S., Zhao, X., Liu, Z., Wang, G., Yuan, K., Liu, W., Kuang, G., Wu, H., 1996. Isotopic and paleomagnetic constraints on the Mesozoic tectonic evolution of south China. Journal of Geophysical Research: Solid Earth 101, 16137-16154.

Goldstein, S.L., O'Nions, R.K., Hamilton, P.J., 1984. A Sm-Nd isotopic study of atmospheric dusts and 
particulates from major river systems. Earth and Planetary Science Letters 70, 221-236.

Griffin, W.L., Belousova, E.A., Shee, S.R., Pearson, N.J., O Reilly, S.Y., 2004. Archean crustal evolution in the northern Yilgarn Craton: $\mathrm{U}-\mathrm{Pb}$ and Hf-isotope evidence from detrital zircons. Precambrian Research 131, 231-282.

Griffin, W.L., Pearson, N.J., Belousova, E., Jackson, S.E., Van Achterbergh, E., O Reilly, S.Y., Shee, S.R., 2000. The Hf isotope composition of cratonic mantle: LAM-MC-ICPMS analysis of zircon megacrysts in kimberlites. Geochimica et Cosmochimica Acta 64, 133-147.

Griffin, W.L., Wang, X., Jackson, S.E., Pearson, N.J., O'Reilly, S.Y., Xu, X., Zhou, X., 2002. Zircon chemistry and magma mixing, SE China: In-situ analysis of Hf isotopes, Tonglu and Pingtan igneous complexes. Lithos 61, 237-269.

Guo, F., Fan, W., Li, C., Zhao, L., Li, H., Yang, J., 2012. Multi-stage crust - mantle interaction in SE China: Temporal, thermal and compositional constraints from the Mesozoic felsic volcanic rocks in eastern Guangdong - Fujian provinces. Lithos 150, 62-84.

Harrison, T.M., McDougall, I., 1980. Investigations of an intrusive contact, northwest Nelson, New Zealand-I. Thermal, chronological and isotopic constraints. Geochimica et Cosmochimica Acta 44, 1985-2003.

He, Z., Xu, X., Niu, Y., 2010. Petrogenesis and tectonic significance of a Mesozoic granite - syenite gabbro association from inland South China. Lithos 119, 621-641.

Hou, K., Li, Y., Zou, T., Qu, X., Shi, Y., Xie, G., 2007. Laser ablation-MC-ICP-MS technique for Hf isotope microanalysis of zircon and its geological applications. Acta Petrologica Sinica 23, 2595-2604(in Chinese with English abstract).

Hsü, K.J., Li, J., Chen, H., Wang, Q., Sun, S., Şengör, A.M.C., 1990. Tectonics of South China: Key to understanding West Pacific geology. Tectonophysics 183, 9-39.

Hsü, K.J., Shu, S., Jiliang, L., Haihong, C., Haipo, P., Sengor, A.M.C., 1988. Mesozoic overthrust tectonics in south China. Geology 16, 418-421.

Hu, G.R., Zhang, B.D., Yu, R.L., 1999. A study on Sm-Nd and Rb-Sr isochron ages of the central Jiangxi metamorphic belt. Geological Review 45, 129-134(in Chinese with English abstract).

Huang, H., Li, X., Li, Z., Li, W., 2015. Formation of the Jurassic South China Large Granitic Province: Insights from the genesis of the Jiufeng pluton. Chemical Geology 401, 43-58.

Huang, S.B., Mao, D.H., Di, Y.J., Wei, Y.W., Luo, P., Li, B.C., 2012. Genetic relationship between rhyolite porphyries and lead-zinc mineralization in Lizikeng volcanic basin,northern Wuyishan. Resources Survey and Environment 33, 152-157(in Chinese with English abstract).

Huang, Z.Q., 1993. The mineralization conditions and deposit characteristics of Lengshuikeng silver orefield in Jiangxi,China. Journal of Precious Metallic Geology 02, 284-291(in Chinese with English abstract).

Iizuka, T., Hirata, T., 2005. Improvements of precision and accuracy in in situ Hf isotope microanalysis of zircon using the laser ablation-MC-ICPMS technique. Chemical Geology 220, 121-137.

Jackson, S.E., Pearson, N.J., Griffin, W.L., Belousova, E.A., 2004. The application of laser ablation-inductively coupled plasma-mass spectrometry to in situ $\mathrm{U}-\mathrm{Pb}$ zircon geochronology. Chemical Geology 211, 47-69.

Jacobsen, S.B., Wasserburg, G.J., 1980. Sm-Nd isotopic evolution of chondrites. Earth and Planetary Science Letters 50, 139-155.

Jahn, B., Condie, K.C., 1995. Evolution of the Kaapvaal Craton as viewed from geochemical and Sm-Nd isotopic analyses of intracratonic pelites. Geochimica et Cosmochimica Acta 59, 
2239-2258.

Jiang, S.Y., Zhao, K.D., Jiang, Y.H., Dai, B.Z., 2008. Characteristics and genesis of Mesozoic A-type granites and associated mineral deposits in the southern Hunan and northern Guangxi provinces along the Shi-Hang Belt, South China. Geological Journal of China Universities 14, 496-509.

Jiang, Y.H., Jiang, S.Y., Dai, B.Z., Liao, S.Y, Zhao, K.D., Ling, H.F., 2009. Middle to late Jurassic felsic and mafic magmatism in southern Hunan province, southeast China: Implications for a continental arc to rifting. Lithos 107, 185-204.

Jiang, Y.H, Jiang, S.Y., Zhao, K.D., Ling, H.F., 2006. Petrogenesis of Late Jurassic Qianlishan granites and mafic dykes, Southeast China: implications for a back-arc extension setting. Geological Magazine 143, 457-474.

Jiang, Y.H, Ling, H.F., Jiang, S.Y., Fan, H.H., Shen, W.Z., Ni, P., 2005. Petrogenesis of a Late Jurassic peraluminous volcanic complex and its high-Mg, potassic, quenched enclaves at Xiangshan, Southeast China. Journal of Petrology 46, 1121-1154.

Jiang, Y.H, Wang, G.C., Liu, Z., Ni, C.Y., Qing, L., Zhang, Q., 2015. Repeated slab advance - retreat of the Palaeo-Pacific plate underneath SE China. International Geology Review 57, 472-491.

Jiang, Y.H, Zhao, P., Zhou, Q., Liao, S., Jin, G., 2011. Petrogenesis and tectonic implications of Early Cretaceous S- and A-type granites in the northwest of the Gan-Hang rift, SE China. Lithos 121, 55-73.

John, B.M., Zhou, X.H., Li, J.L., 1990. Formation and tectonic evolution of Southeastern China and Taiwan: Isotopic and geochemical constraints. Tectonophysics 183, 145-160.

King, P.L., White, A., Chappell, B.W., Allen, C.M., 1997. Characterization and origin of aluminous A-type granites from the Lachlan Fold Belt, southeastern Australia. Journal of petrology 38, 371-391.

Lapierre, H., Jahn, B.M., Charvet, J., Yu, Y.W., 1997. Mesozoic felsic arc magmatism and continental olivine tholeiites in Zhejiang Province and their relationship with the tectonic activity in southeastern China. Tectonophysics 274, 321-338.

Le Bas, M.J., Le Maitre, R.W., Streckeisen, A., Zanettin, B., 1986. A chemical classification of volcanic rocks based on the total alkali-silica diagram. Journal of petrology 27, 745-750.

Lee, J.K., Williams, I.S., Ellis, D.J., 1997. Pb, U and Th diffusion in natural zircon. Nature 390, 159-162.

Li, K.Y., Shen, J.L., Wang, X.P., 1989. Isotopic geochronology of Mesozoic terrestrial volcanic rocks in the Zhejiang- Fujian- Jiangxi area. Journal of Stratigraphy 13, 1-13(in Chinese with English abstract).

Li, L., Sun, M., Wang, Y., Xing, G., Zhao, G., Lin, S., Xia, X., Chan, L., Zhang, F., Wong, J., 2011. U $-\mathrm{Pb}$ and $\mathrm{Hf}$ isotopic study of zircons from migmatised amphibolites in the Cathaysia Block: Implications for the early Paleozoic peak tectonothermal event in Southeastern China. Gondwana Research 19, 191-201.

Li, P.J, Yu, X.Q., Li, H.Y., Qiu, J.T., Zhou, X., 2013. Jurassic - Cretaceous tectonic evolution of southeast China: geochronological and geochemical constraints of Yanshanian granitoids. International Geology Review 55, 1202-1219.

Li, S.G., Chen, Y.Z., Ge, N.J., Hu, X.J., Liu, D.L., 1996. Isotopic ages of metavolcanic rocks and megacryst mylonite in the Badu group in Southwestern Zhejiang Province and their implications for tectonics. Acta Petrologica Sinica 12, 79-87 (in Chinese with English abstract).

Li, W.X., Li, X.H., Li, Z.X., Lou, F.S., 2008. Obduction-type granites within the NE Jiangxi Ophiolite: 
Implications for the final amalgamation between the Yangtze and Cathaysia Blocks. Gondwana Research 13, 288-301.

Li, X.H., 2000. Cretaceous magmatism and lithospheric extension in Southeast China. Journal of Asian Earth Sciences 18, 293-305.

Li, X.H., Chen, Z.G., Liu, D.Y., Li, W.X., 2003. Jurassic gabbro-granite-syenite suites from southern Jiangxi Province, SE China: Age, origin, and tectonic significance. International Geology Review $45,898-921$.

Li, X.H., Li, Z.X., Li, W.X., Liu, Y., Yuan, C., Wei, G.J., Qi, C.S., 2007. U - Pb zircon, geochemical and $\mathrm{Sr}-\mathrm{Nd}-\mathrm{Hf}$ isotopic constraints on age and origin of Jurassic I- and A-type granites from central Guangdong, SE China: A major igneous event in response to foundering of a subducted flat-slab? Lithos 96, 186-204.

Li, X.H., 1997. Timing of the Cathaysia Block formation: Constraints from SHRIMP U-Pb zircon geochronology. Episodes 20, 188-192.

Li, X.H., Chung, S.L., Zhou, H., Lo, C.H., Liu, Y., Chen, C.H., 2004. Jurassic intraplate magmatism in southern Hunan-eastern Guangxi: ${ }^{40} \mathrm{Ar} /{ }^{39} \mathrm{Ar}$ dating, geochemistry, Sr-Nd isotopes and implications for the tectonic evolution of SE China. Geological Society, London, Special Publications 226, 193-215.

Li, Z.X., Li, X.H., 2007. Formation of the 1300-km-wide intracontinental orogen and postorogenic magmatic province in Mesozoic South China: a flat-slab subduction model. Geology 35, 179-182.

Li, Z., Qiu, J.S., Yang, X., 2014. A review of the geochronology and geochemistry of Late Yanshanian (Cretaceous) plutons along the Fujian coastal area of southeastern China: Implications for magma evolution related to slab break-off and rollback in the Cretaceous. Earth-Science Reviews 128, 232-248.

Li, Z.X., Li, X.H., Wartho, J.A., Clark, C., Li, W.X., Zhang, C.L., Bao, C., 2010. Magmatic and metamorphic events during the early Paleozoic Wuyi-Yunkai orogeny, southeastern South China: New age constraints and pressure-temperature conditions. Geological Society of America Bulletin 122, $772-793$.

Liew, T.C., Hofmann, A.W., 1988. Precambrian crustal components, plutonic associations, plate environment of the Hercynian Fold Belt of central Europe: indications from a $\mathrm{Nd}$ and $\mathrm{Sr}$ isotopic study. Contributions to Mineralogy and Petrology 98, 129-138.

Liu, J.Y., 1985. Xiangshan igneous pluton: A granitic hypabyssal intrusive volcanic complex. Geochimica 14, 142-149 (in Chinese with English abstract).

Liu, L., Xu, X., Zou, H., 2012. Episodic eruptions of the Late Mesozoic volcanic sequences in southeastern Zhejiang, SE China: Petrogenesis and implications for the geodynamics of paleo-Pacific subduction. Lithos 154, 166-180.

Ludwig, K.R., 2003. User's manual for Isoplot 3.00: A geochronological toolkit for Microsoft Excel. Berkeley Geochronological Center Special Publication, Berkeley.

Lugmair, G.W., Marti, K., 1978. Lunar initial ${ }^{143} \mathrm{Nd} /{ }^{144} \mathrm{Nd}$ : Differential evolution of the lunar crust and mantle. Earth and Planetary Science Letters 39, 349-357.

McDonough, W.F., Sun, S.S., 1995. The composition of the Earth. Chemical Geology 120, 223-253.

Meng, L., Li, Z., Chen, H., Li, X., Wang, X., 2012. Geochronological and geochemical results from Mesozoic basalts in southern South China Block support the flat-slab subduction model. Lithos 132-133, 127-140.

Meng, X.J., Hou, Z.Q., Dong, G.Y., Liu, J.G., Zuo, L.Y., Yang, Z.S., Xiao, M.Z., 2009. Geological 
characteristics and mineralization timing of the Lengshuikeng porphyry $\mathrm{Pb}-\mathrm{Zn}-\mathrm{Ag}$ deposit, Jiangxi Province. Acta Geologica Sinica 83, 1951-1967 (in Chinese with English abstract).

Meng, X.J., Xu, W.Y., Yang, Z.S., Hou, Z.Q., Li, Z.Q., Yu, Y.S., Xiao, M.Z., He, X.R., Wan, H.Z., 2012. Time limit of volcanic-magmatic action in Lengshuikeng orefield, Jiangxi: Evidence from SHRIMP zircon U-Pb ages. Mineral Deposits 31, 831-838 (in Chinese with English abstract).

Morrison, G.W., 1980. Characteristics and tectonic setting of the shoshonite rock association. Lithos 13, 97-108.

Müller, D.D., Rock, N., Groves, D.I., 1992. Geochemical discrimination between shoshonitic and potassic volcanic rocks in different tectonic settings: a pilot study. Mineralogy and Petrology 46, 259-289.

Nash, W.P., Crecraft, H.R., 1985. Partition coefficients for trace elements in silicic magmas. Geochimica et Cosmochimica Acta 49, 2309-2322.

Norrish, K., Hutton, J.T., 1969. An accurate X-ray spectrographic method for the analysis of a wide range of geological samples. Geochimica et Cosmochimica Acta 33, 431-453.

Nowell, G.M., Kempton, P.D., Noble, S.R., Fitton, J.G., Saunders, A.D., Mahoney, J.J., Taylor, R.N., 1998. High precision Hf isotope measurements of MORB and OIB by thermal ionisation mass spectrometry: insights into the depleted mantle. Chemical Geology 149, 211-233.

Patino Douce, A.E., 1997. Generation of metaluminous A-type granites by low-pressure melting of calc-alkaline granitoids. Geology 25, 743.

Patino Douce, A.E., Beard, J.S., 1995. Dehydration-melting of biotite gneiss and quartz amphibolite from 3 to 15 kbar. Journal of Petrology 36, 707-738.

Patiňo Douce, A.E., Johnston, A.D., 1991. Phase equilibria and melt productivity in the pelitic system: implications for the origin of peraluminous granitoids and aluminous granulites. Contributions to Mineralogy and Petrology 107, 202-218.

Pearce, J.A., Harris, N.B., Tindle, A.G., 1984. Trace element discrimination diagrams for the tectonic interpretation of granitic rocks. Journal of Petrology 25, 956-983.

Pu, W., Gao, J.F., Zhao, K.D., 2004. High precision Nd isotope measurement by Triton TI Mass Spectrometry. Acta Geoscientica Sinica 25, 271-274 (in Chinese with English abstract).

Pu, W., Gao, J.F., Zhao, K.D., 2005. Separation method of Rb-Sr, Sm-Nd using DCTA and HIBA. Journal of Nanjing University (Natural Sciences) 41, 445-450 (in Chinese with English abstract).

Qi, Y.Q., Hu, R.Z., Liu, S., Coulson, I.M., Qi, H.W., Tian, J.J., Feng, C.X., Wang, T., 2013. Geochemical and $\mathrm{Sr}-\mathrm{Nd}-\mathrm{Pb}$ isotopic compositions of Mesozoic mafic dikes from the Gan-Hang tectonic belt, South China: petrogenesis and geodynamic significance. International Geology Review 54, 920-939.

Qiu, J.T., Yu, X.Q., Wu, G.G., Liu, J.G., Xiao, M.Z., 2013. Geochronology of igneous rocks and nappe structures in Lengshuikeng deposit,Jiangxi Province,China. Acta Petrologica Sinica 29, 812-826 (in Chinese with English abstract).

Rapp, R.P., Watson, E.B., 1995. Dehydration melting of metabasalt at 8 - 32 kbar: implications for continental growth and crust-mantle recycling. Journal of Petrology 36, 891-931.

Rogers, N.W., James, D., Kelley, S.P., De Mulder, M., 1998. The generation of potassic lavas from the eastern Virunga province, Rwanda. Journal of Petrology 39, 1223-1247.

Sisson, T.W., Ratajeski, K., Hankins, W.B., Glazner, A.F., 2005. Voluminous granitic magmas from common basaltic sources. Contributions to Mineralogy and Petrology 148, 635-661.

Smith, D.R., Noblett, J., Wobus, R.A., Unruh, D., Douglass, J., Beane, R., Davis, C., Goldman, S., Kay, 
G., Gustavson, B., 1999. Petrology and geochemistry of late-stage intrusions of the A-type, mid-Proterozoic Pikes Peak batholith (Central Colorado, USA): implications for petrogenetic models. Precambrian Research 98, 271-305.

Söderlund, U., Patchett, P.J., Vervoort, J.D., Isachsen, C.E., 2004. The 176Lu decay constant determined by $\mathrm{Lu}-\mathrm{Hf}$ and $\mathrm{U}-\mathrm{Pb}$ isotope systematics of Precambrian mafic intrusions. Earth and Planetary Science Letters 219, 311-324.

Steiger, R.H., Jäger, E., 1977. Subcommission on geochronology: convention on the use of decay constants in geo-and cosmochronology. Earth and Planetary Science Letters 36, 359-362.

Su, H.M., Mao, J.W., Santosh, M., Xie, G.Q., 2014. Petrogenesis and tectonic significance of Late Jurassic - Early Cretaceous volcanic-intrusive complex in the Tianhuashan basin, South China. Ore Geology Reviews 56, 566-583.

Thirlwall, M.F., Smith, T.E., Graham, A.M., Theodorou, N., Hollings, P., Davidson, J.P., Arculus, R.J., 1994. High field strength element anomalies in arc lavas: source or process? Journal of Petrology $35,819-838$.

Turner, S., Arnaud, N., LIU, J., Rogers, N., Hawkesworth, C., Harris, N., Kelley, S., Van Calsteren, P., Deng, W., 1996. Post-collision, shoshonitic volcanism on the Tibetan Plateau: implications for convective thinning of the lithosphere and the source of ocean island basalts. Journal of Petrology 37, 45-71.

Turner, S.P., Foden, J.D., Morrison, R.S., 1992. Derivation of some A-type magmas by fractionation of basaltic magma: an example from the Padthaway Ridge, South Australia. Lithos 28, 151-179.

Van Achterbergh, E., Ryan, C.G., Jackson, S.E., Griffin, W.L., 2001. Data reduction software for LA-ICP-MS. Laser-Ablation-ICPMS in the earth sciences-principles and applications. Miner Assoc Can (short course series) 29, 239-243.

Villa, I.M., 1998. Isotopic closure. Terra Nova-Oxford 10, 42-47.

Wan, Y., Wilde, S.A., Liu, D., Yang, C., Song, B., Yin, X., 2006. Further evidence for $\sim 1.85$ Ga metamorphism in the Central Zone of the North China Craton: SHRIMP U - Pb dating of zircon from metamorphic rocks in the Lushan area, Henan Province. Gondwana Research 9, 189-197.

Wang, C.M., Zhang, D., Wu, G.G., Xu, Y.G., Carranza, E.J.M., Zhang, Y.Y., Li, H.K., Geng, J.Z., 2013. Zircon $\mathrm{U}-\mathrm{Pb}$ geochronology and geochemistry of rhyolitic tuff, granite porphyry and syenogranite in the Lengshuikeng ore district, SE China: Implications for a continental arc to intra-arc rift setting. Journal of Earth System Science, 1-22.

Wang, Y., Fan, W., Sun, M., Liang, X., Zhang, Y., Peng, T., 2007. Geochronological, geochemical and geothermal constraints on petrogenesis of the Indosinian peraluminous granites in the South China Block: A case study in the Hunan Province. Lithos 96, 475-502.

Wang, Y., Fan, W., Zhang, G., Zhang, Y., 2013. Phanerozoic tectonics of the South China Block: Key observations and controversies. Gondwana Research 23, 1273-1305.

Watson, E.B., Harrison, T.M., 1983. Zircon saturation revisited: temperature and composition effects in a variety of crustal magma types. Earth and Planetary Science Letters 64, 295-304.

Whalen, J.B., Currie, K.L., Chappell, B.W., 1987. A-type granites: geochemical characteristics, discrimination and petrogenesis. Contributions to Mineralogy and Petrology 95, 407-419.

Whalen, J.B., Jenner, G.A., Longstaffe, F.J., Robert, F., Gariepy, C., 1996. Geochemical and Isotopic $(\mathrm{O}, \mathrm{Nd}, \mathrm{Pb}$ and $\mathrm{Sr}$ ) Constraints on A-type Granite Petrogenesis Based on the Topsails Igneous Suite, Newfoundland Appalachians. Journal of Petrology 37, 1463-1489.

Whalen, J.B., McNicoll, V.J., van Staal, C.R., Lissenberg, C.J., Longstaffe, F.J., Jenner, G.A., van 
Breeman, O., 2006. Spatial, temporal and geochemical characteristics of Silurian collision-zone magmatism, Newfoundland Appalachians: An example of a rapidly evolving magmatic system related to slab break-off. Lithos 89, 377-404.

Wiedenbeck, M., Alle, P., Corfu, F., Griffin, W.L., Meier, M., Oberli, F., Quadt, A.V., Roddick, J.C., Spiegel, W., 1995. Three natural zircon standards for $\mathrm{U}-\mathrm{Th}-\mathrm{Pb}, \mathrm{Lu}-\mathrm{Hf}$, trace element and REE analyses. Geostandards Newsletter 19, 1-23.

Wong, J., Sun, M., Xing, G., Li, X., Zhao, G., Wong, K., Wu, F., 2011. Zircon U - Pb and Hf isotopic study of Mesozoic felsic rocks from eastern Zhejiang, South China: Geochemical contrast between the Yangtze and Cathaysia blocks. Gondwana Research 19, 244-259.

Wong, J., Sun, M., Xing, G., Li, X., Zhao, G., Wong, K., Yuan, C., Xia, X., Li, L., Wu, F., 2009. Geochemical and zircon $\mathrm{U}-\mathrm{Pb}$ and $\mathrm{Hf}$ isotopic study of the Baijuhuajian metaluminous A-type granite: Extension at $125-100 \mathrm{Ma}$ and its tectonic significance for South China. Lithos 112, 289-305.

Woodhead, J.D., Hergt, J.M., 2005. A preliminary appraisal of seven natural zircon reference materials for in situ Hf isotope determination. Geostandards and Geoanalytical Research 29, 183-195.

Wright, J.B., 1969. A simple alkalinity ratio and its application to questions of non-orogenic granite genesis. Geological Magazine 106, 370-384.

Wu, F., Yang, Y., Xie, L., Yang, J., Xu, P., 2006. Hf isotopic compositions of the standard zircons and baddeleyites used in $\mathrm{U}$ - Pb geochronology. Chemical Geology 234, 105-126.

Wu, J.Q., Tan, G.L., Zhang, B.D., Ling, H.F., Chen, P.R., 2011. Identification and Genesis of the Early Cretaceous Shoshonitic Volcanic Rock Series in Central Jiangxi Province. Geological Journal of China Universities 17, 479-491 (in Chinese with English abstract).

Xing, G.F., Lu, Q.D., Chen, R., Zhang, Z.Y., Nie, T.C., Li, L.M., Huang, J.L., Lin, M., 2008. Study on the ending time of Late Mesozoic tectonic regime transition in South China: comparing to the Yanshan area in North China. Acta Geologica Sinica 82, 451-463 (in Chinese with English abstract).

Xu, W.X., Xiao, M.H., Chen, M.Y., 2001. A study of the isotope geochemistry of the Lengshuikeng $\mathrm{Ag}-\mathrm{Pb}-\mathrm{Zn}$ ore deposit,Jiangxi Province. Bulletin of Mineralogy, Petrology and Geochemistry 20, 370-372 (in Chinese with English abstract).

Xu, W.X., Xiao, M.H., Chen, M.Y., 2002. A study of isotope geochemistry of the Lengshuikeng $\mathrm{Ag}-\mathrm{Pb}-\mathrm{Zn}$ ore deposit in Jiangxi. Geological Review 48, 193-197 (in Chinese with English abstract).

Xu, X.S., O Reilly, S.Y., Griffin, W.L., Wang, X.L., Pearson, N.J., He, Z.Y., 2007. The crust of Cathaysia: age, assembly and reworking of two terranes. Precambrian Research 158, 51-78.

Xu, X.S., O'Reilly, S.Y., Griffin, W.L., Deng, P., Pearson, N.J., 2005. Relict Proterozoic basement in the Nanling Mountains (SE China) and its tectonothermal overprinting. Tectonics 24, 1-16.

$\mathrm{Xu}, \mathrm{X} . \mathrm{S} .$, 2008. Several problems worthy to be noticed in the rewearch of granites and volcanic rocks in SE China. Geological Journal of China Universities 14, 283-294 (in Chinese with English abstract).

Xu, Y.G., Wu, G.G., Wang, C.M., Zhang, D., Zhang, Y.Y., 2013. Rb-Sr dating of sphalerites from the Lengshuikeng Ag-Pb-Zn deposit, Jiangxi,and its geological significances. Acta Geologica Sinica 87, 621-633 (in Chinese with English abstract).

Yang, S., Jiang, S., 2013. Occurrence and significance of a quartz - amphibole schist xenolith within a mafic microgranular enclave in the Xiangshan volcanic-intrusive complex, SE China. International 
Geology Review 55, 894-903.

Yang, S., Jiang, S., Jiang, Y., Zhao, K., Fan, H., 2011. Geochemical, zircon U - Pb dating and $\mathrm{Sr}-\mathrm{Nd}$

- Hf isotopic constraints on the age and petrogenesis of an Early Cretaceous volcanic-intrusive complex at Xiangshan, Southeast China. Mineralogy and Petrology 101, 21-48.

Yang, S., Jiang, S., Zhao, K., Jiang, Y., 2013. Petrogenesis and tectonic significance of Early Cretaceous high-Zr rhyolite in the Dazhou uranium district, Gan-Hang Belt, Southeast China. Journal of Asian Earth Sciences 74, 303-315.

Yang, S., Jiang, S., Zhao, K., Jiang, Y., Ling, H., Luo, L., 2012. Geochronology, geochemistry and tectonic significance of two Early Cretaceous A-type granites in the Gan-Hang Belt, Southeast China. Lithos 150, 155-170.

Yang, S.Y., Jiang, S.Y., Zhao, K.D., Jiang, Y.H., Ling, H.F., Chen, P.R., 2013. Timing and geological implications of volcanic rocks from the Ruyiting section, Xiangshan uranium ore field, Jiangxi Province, SE China. Acta Petrologica Sinica 29, 4362-4372 (in Chinese with English abstract).

Ye, M., Li, X., Li, W., Liu, Y., Li, Z., 2007. SHRIMP zircon U - Pb geochronological and whole-rock geochemical evidence for an early Neoproterozoic Sibaoan magmatic arc along the southeastern margin of the Yangtze Block. Gondwana Research 12, 144-156.

Yu, J., Wang, L., O Reilly, S.Y., Griffin, W.L., Zhang, M., Li, C., Shu, L., 2009. A Paleoproterozoic orogeny recorded in a long-lived cratonic remnant (Wuyishan terrane), eastern Cathaysia Block, China. Precambrian Research 174, 347-363.

Yu, X.Q., Wu, G.G., Shu, L.S., Yan, T.Z., Zhang, D., Di, Y.J., 2006. The Cretaceous tectonism of the Gan-Hang Tectonic Belt, southeastern China. Earth Science Frontiers 13, 31-43.

Yuan, Z.X., Wu, L.S., Zhang, Z.Q., Ye, X.J., 1991. The Sm-Nd, Rb-Sr isotopic age-dating of Mayuan group in northern Fujian. Acta Petrologica et Mineralogica 10, 127-132.

Zhang, J.J., Wang, D.H., Liu, S.B., Chen, Z.H., Shi, G.H., Wang, J., Wang, Y.Q., Wei, Y.W., 2012. Geochronology and isotopic compositions of the Huangbi lead-zinc deposits, Jiangxi, China. Acta Petrologica Sinica 28, 3325-3333 (in Chinese with English abstract).

Zhang, J.J., Wu, M.S., Chen, Z.H., Liu, S.B., Li, L.X., Qiu, L.M., Wu, B., Huang, A.J., Zhu, P.J., 2009. Geochronologic study on the Jinzhuping molybdenum-polymetallic deposit from Shangrao of Jiangxi Province. Rock and Mineral Analysis 28, 228-232 (in Chinese with English abstract).

Zhang, W.L., 2000. Stratigraphic attribution of volcanic series in Shengyuan basin. Uranium Geology 16, 99-101 (in Chinese with English abstract).

Zhang, W.L., Li, Z.Y., 2007. Single-zircon U-Pb age of rhyodacite from Xiangshan area and its geological implications. Acta Petrologica et Mineralogica 26, 21-26 (in Chinese with English abstract).

Zhang, Y.Q., Xu, X.B., Jia, D., Shu, L.S., 2009. Deformation record of the change from Indosinian collision-related tectonic system to Yanshanian subduction-related tectonic system in South China during the Early Mesozoic. Earth Science Frontiers 16, 234-247.

Zhao, J., Hu, R., Zhou, M., Liu, S., 2007. Elemental and $\mathrm{Sr}-\mathrm{Nd}-\mathrm{Pb}$ isotopic geochemistry of Mesozoic mafic intrusions in southern Fujian Province, SE China: implications for lithospheric mantle evolution. Geological Magazine 144, 937-952.

Zhao, K., Jiang, S., Yang, S., Dai, B., Lu, J., 2012. Mineral chemistry, trace elements and Sr - Nd - Hf isotope geochemistry and petrogenesis of Cailing and Furong granites and mafic enclaves from the Qitianling batholith in the Shi-Hang zone, South China. Gondwana Research 22, 310-324.

Zhou, J., Jiang, Y., Xing, G., Zeng, Y., Ge, W., 2013. Geochronology and petrogenesis of Cretaceous 
A-type granites from the NE Jiangnan Orogen, SE China. International Geology Review 55, 1359.

Zhou, X., Sun, T., Shen, W., Shu, L., Niu, Y., 2006. Petrogenesis of Mesozoic granitoids and volcanic rocks in South China: a response to tectonic evolution. Episodes 29, 26-32.

Zhou, X.M., Li, W.X., 2000. Origin of Late Mesozoic igneous rocks in Southeastern China: implications for lithosphere subduction and underplating of mafic magmas. Tectonophysics 326, 269-287.

Zhu, Z., Jiang, S., Liu, G., Zhao, K., 2013. Precise dating of the Middle Permian: Zircon U $-\mathrm{Pb}$ geochronology from volcanic ash beds in the basal Gufeng Formation, Yangtze region, South China. Gondwana Research 23, 1599-1606.

Zuo, L.Y., Hou, Z.Q., Meng, X.J., Yang, Z.M., Song, Y.C., Li, Z., 2010. SHRIMP U - Pb zircon geochronology of the ore-bearing rock in the Lengshuikeng porphyry type $\mathrm{Ag}-\mathrm{Pb}-\mathrm{Zn}$ deposit. Geology in China 37, 1450-1456 (in Chinese with English abstract).

Zuo, L.Y., Meng, X.J., Yang, Z.S., 2008. Petrochemistry and Sr, Nd isotopes of intrusive in Lengshuikeng porphyry type Ag - Pb - Zn deposit. Mineral Deposits 27, 367-382 (in Chinese with English abstract). 


\section{Figure captions:}

Fig. 1. Geological sketch map showing the Gan-Hang Belt in Southeast China (modified from $\mathrm{Yu}$ et al., 2006).

Fig. 2. Geological map of the Lengshuikeng ore district (modified from the 912 Geological Team, Bureau of Geology and Mineral Resources of Jiangxi Province).

Fig. 3. Photomicrographs of representative volcanic rocks from the Lengshuikeng district (crossed nicols). (a) crystal tuff from the Daguding Fm., 150-245; (b) crystal tuff from the Daguding Fm., 701-702; (c) crystal tuff from the Daguding Fm., 701-840; (d) rhyolitic crystal ignimbrite from the Ehuling Fm., LS69; (e) lithic crystal ignimbrite from the Ehuling Fm., LS79; (f) rhyolitic crystal ignimbrite from the Ehuling Fm., 701-246; Qz—quartz.

Fig. 4. CL images of representative zircons from volcanic rocks of the Lengshuikeng district. Smaller solid circles indicate the spots of $\mathrm{U}-\mathrm{Pb}$ dating, whereas larger dashed circles indicate the spots of $\mathrm{Hf}$ isotope analyses. Age and $\varepsilon \mathrm{Hf}(\mathrm{t})$ values are also shown for each spot. All scale bars represent $100 \mu \mathrm{m}$.

Fig. 5. Zircon $\mathrm{U}-\mathrm{Pb}$ Concordia diagrams and weighted average ${ }^{206} \mathrm{~Pb} /{ }^{238} \mathrm{U}$ ages for volcanic rocks of the Daguding Fm. (a, b, c, d, e, f) and the Ehuling Fm. (g, h, i, j, k).

Fig. 6. Histograms of $\varepsilon_{\mathrm{Hf}}(\mathrm{t})$ values of zircons from volcanic rocks of the Daguding Fm. and the Ehuling Fm.

Fig. 7. $\mathrm{T}_{\mathrm{DM} 2}$ distribution of zircons from volcanic rocks of northern Wuyi Mountain Belt and U-Pb age spectra of detrital zircon populations (Xu et al., 2007) from the eastern Cathaysia Block. The shaded region indicates the ages of the Paleoproterozoic granitoids and coeval metamorphic rocks (Chen and Jahn, 1998; Li et al., 1996; Li, 1997; Li et al., 2010; Xu et al., 2005; Xu et al., 2007; Yu et al., 2009; Yuan et al., 1991).

Fig. 8. Total alkali-silica (TAS) diagram of volcanic rocks from the Daguding and Ehuling Fms. (Le Bas et al., 1986).

Fig. 9. $\mathrm{SiO}_{2}$ vs. ASI $\left[=\right.$ molar $\left.\mathrm{Al}_{2} \mathrm{O}_{3} /\left(\mathrm{CaO}+\mathrm{Na}_{2} \mathrm{O}+\mathrm{K}_{2} \mathrm{O}\right)\right]$ (a), $\mathrm{K}_{2} \mathrm{O}$ (b) and $\mathrm{Mg} \#[=\mathrm{Mg} /(\mathrm{Mg}+\mathrm{FeT})]$ (c) diagrams for the Daguding and Ehuling volcanic rocks. In (c), also shown are the fields of pure crustal partial melts obtained in experimental studies by the dehydration melting of low-K basaltic rocks at 8-16 kbar and 1000-1050 ${ }^{\circ} \mathrm{C}$ (Rapp and Watson, 1995), of moderately hydrous (1.7-2.3 wt $\% \mathrm{H}_{2} \mathrm{O}$ ) medium- to high-K basaltic rocks at 7 kbar and 825-950 ${ }^{\circ} \mathrm{C}$ (Sisson et al., 2005), of pelitic rocks at 7-13 kbar and 825-950 ${ }^{\circ} \mathrm{C}$ (Patiňo Douce and Johnston, 1991) and of biotite gneiss and quartz amphibolite at $7-15 \mathrm{kbar}$ and $900-1000^{\circ} \mathrm{C}$ (Patino Douce and Beard, 1995). The symbols are the same as those in Fig. 8 . 
Fig. 10. AR vs. $\mathrm{SiO}_{2}$ diagram (Wright, 1969) for volcanic rocks of the Daguding and Ehuling Fms., where AR (alkalinity ratio) $=\left[\mathrm{Al}_{2} \mathrm{O}_{3}+\mathrm{CaO}+\left(\mathrm{Na}_{2} \mathrm{O}+\mathrm{K}_{2} \mathrm{O}\right)\right] /\left[\mathrm{Al}_{2} \mathrm{O}_{3}+\mathrm{CaO}-\left(\mathrm{Na}_{2} \mathrm{O}+\mathrm{K}_{2} \mathrm{O}\right)\right]($ wt. \%) . The symbols are the same as those in Fig. 8.

Fig. 11. (a) Chondrite-normalized REE patterns (normalization values are from Boynton, 1984) and (b) primitive-mantle-normalized multi-element spidergrams (normalization values are from McDonough and Sun, 1995) for volcanic rocks of the Daguding Fm and the Ehuling Fm.

Fig. 12. (a) $\mathrm{Zr}$ vs. $10000 \times \mathrm{Ga} / \mathrm{Al}$, (b) $\mathrm{FeO} * \mathrm{MgO}$ vs. $(\mathrm{Zr}+\mathrm{Nb}+\mathrm{Ce}+\mathrm{Y})$ discrimination diagrams (after Whalen et al., 1987), showing the A-type nature of the Ehuling volcanic rock, and (c) the A-type granite subdivision diagrams of $\mathrm{Nb}-\mathrm{Y}-3 \times \mathrm{Ga}$ and (d) $\mathrm{Rb} / \mathrm{Nb}$ vs. $\mathrm{Y} / \mathrm{Nb}$ (after Eby, 1992), showing that the Ehuling volcanic rocks belong to the $\mathrm{A}_{2}$ group. FG: fractionated felsic granites; OGT: unfractionated I-, S- and M-type granites. The symbols are the same as those in Fig. 8.

Fig. 13. Initial ${ }^{87} \mathrm{Sr} /{ }^{86} \mathrm{Sr}\left(\mathrm{I}_{\mathrm{Sr}}\right)$ vs $\varepsilon_{\mathrm{Nd}}(\mathrm{t})$ diagram for the volcanic-intrusive complex and mafic microgranular enclaves from the Xiangshan. The $\mathrm{Sr}$ and $\mathrm{Nd}$ isotope data for orthometamorphic and parametamorphic rocks are from Yuan et al. (1991) and Hu et al. (1999). The initial ${ }^{87} \mathrm{Sr} /{ }^{86} \mathrm{Sr}$ ratios $\left(\mathrm{I}_{\mathrm{Sr}}\right)$ and $\varepsilon_{\mathrm{Nd}}(\mathrm{t})$ values were calculated based on respective zircon $\mathrm{U}-\mathrm{Pb}$ ages determined in this study. The symbols are the same as those in Fig. 8.

Fig. 14. (a) Columnar section of ZK15701 showing the sampling horizons and corresponding ages of this work and (b) geochronological results of previous work and this work and their distributions. Previous dating results of the volcanic rocks are shown in Table 4.

Fig. 15. ACF diagrams showing the relationship between the chemistry and mineralogy of Daguding volcanic rocks. The hatched area of the diagram corresponds to peraluminous rock compositions (Chappell and White, 1992).

Fig. 16. Diagram of $\varepsilon_{\mathrm{Hf}}(\mathrm{t})$ vs. U-Pb ages of zircons from the volcanic rocks in the Tianhuashan basin with the shaded region indicating $\mathrm{Hf}$ isotope evolution for the crustal basement of the eastern Cathaysia Block after Xu et al. (2007).

Fig. 17. Eu vs. $\mathrm{Rb}(\mathrm{a}), \mathrm{Ba}(\mathrm{b}), \mathrm{Sr}(\mathrm{c})$ and $\mathrm{Yb}(\mathrm{d})$ diagrams for Ehuling A-type volcanic rocks. Trends illustrate crystal fractionation of biotite (Bt), plagioclase (Pl) and K-feldspar (Kfs) starting with initial concentration (701-258). Tic marks along these arrows indicate the weight fraction of fractionation melt. The partition coefficient data for minerals in equilibrium with silicic liquids are from Nash and Crecraft (1985).

Fig 18. (a) Y-Nb and (b) Yb-Ta diagram (Pearce et al., 1984) for volcanic rocks, VAG: volcanic arc granites. The contemporaneous granitoids in the WZG region are also plotted for comparison (Li et al., 2013). WPG: within plate granites, ORG: ocean ridge granites. The symbols are the same as those in Fig. 8.

Fig. 19. Schematic diagram showing the Late Mesozoic tectonic evolution and magma generation processes in the Tianhuashan basin. The Late Jurassic Daguding volcanic rocks were formed in a 
continental arc environment associated with the subduction of the Paleo-Pacific plate (a). The Early Cretaceous Ehuling volcanic rocks were formed in a continental arc-rifting setting as a consequence of slab rollback (b). See text for more discussion. Revised after Zhou and Li (2000) and Jiang et al. (2015) 


\section{Table captions:}

Table 1 Strata in the Lengshuikeng district (modified from the 912 Geological Team, Bureau of Geology and Mineral Resources of Jiangxi Province).

Table 2 Lithologies, pyroclast assemblages and sample locations of the Late Mesozoic volcanic rocks from the Lengshuikeng district.

Table 3 Major (wt.\%), trace elements (ppm) and Sr-Nd isotope compositions for volcanic rocks of the Daguding and Ehuling Fms.

Table 4 Compilation of isotope age for the Late Mesozoic volcanism in the northeastern Jiangxi Province. 


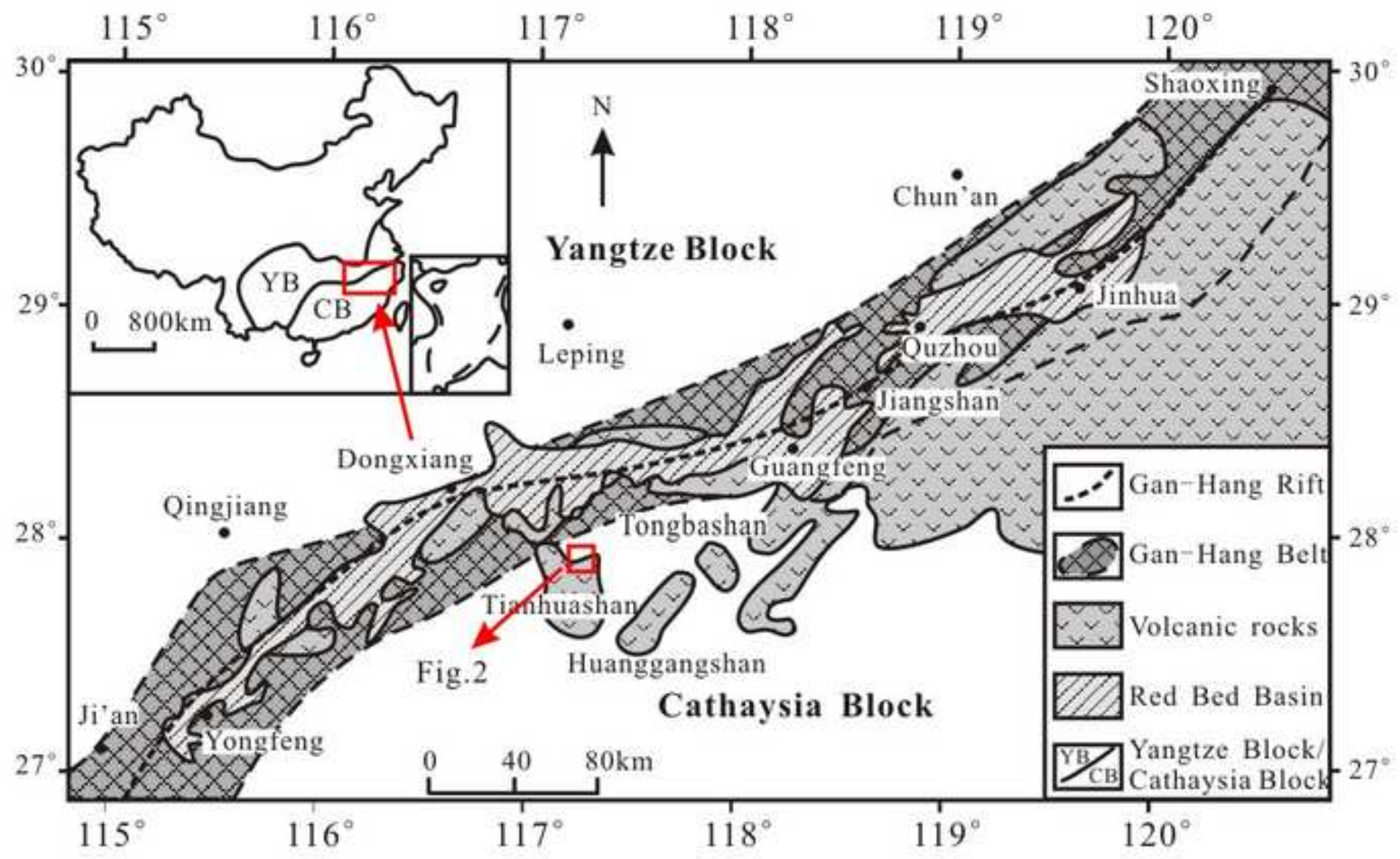




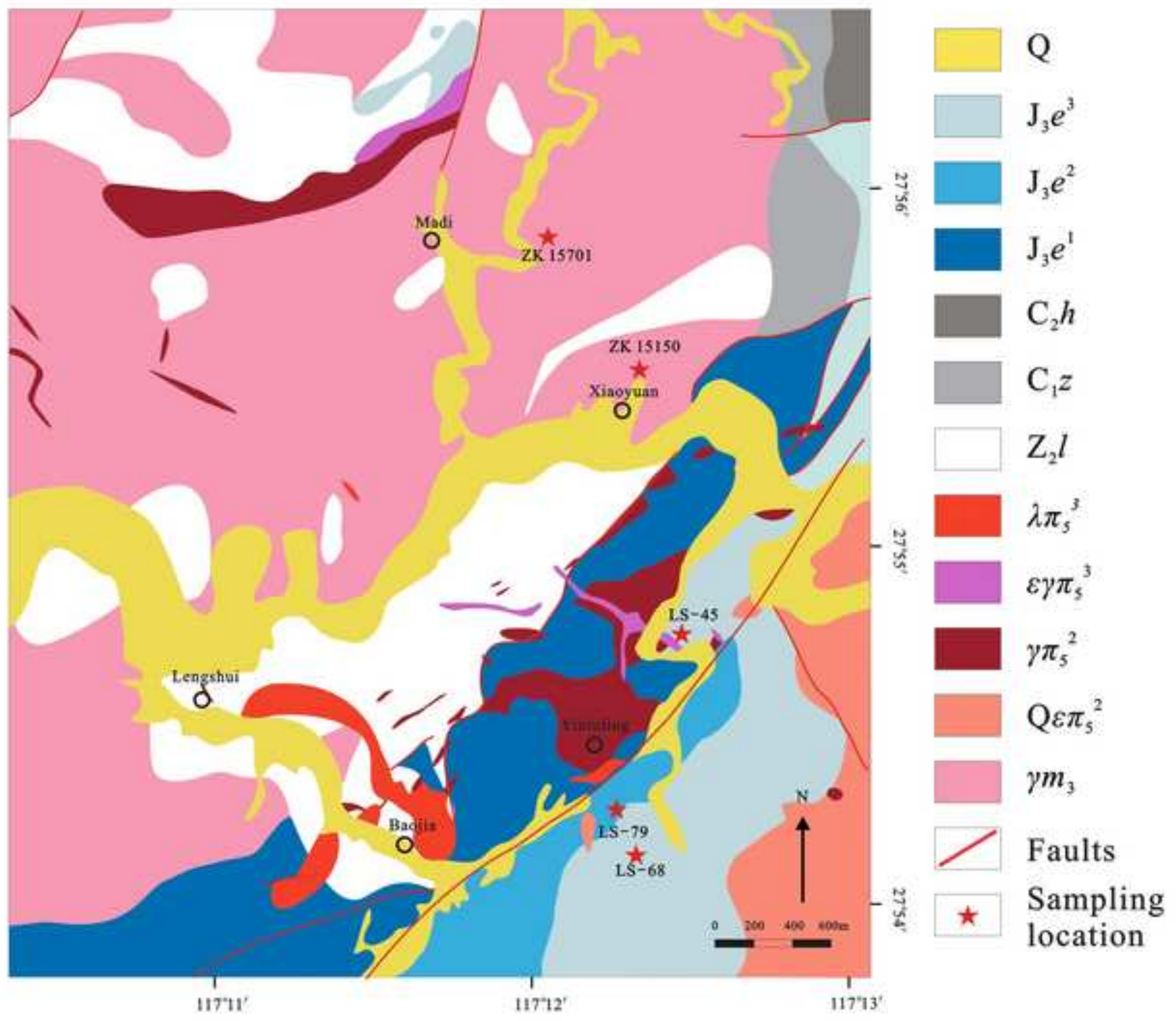



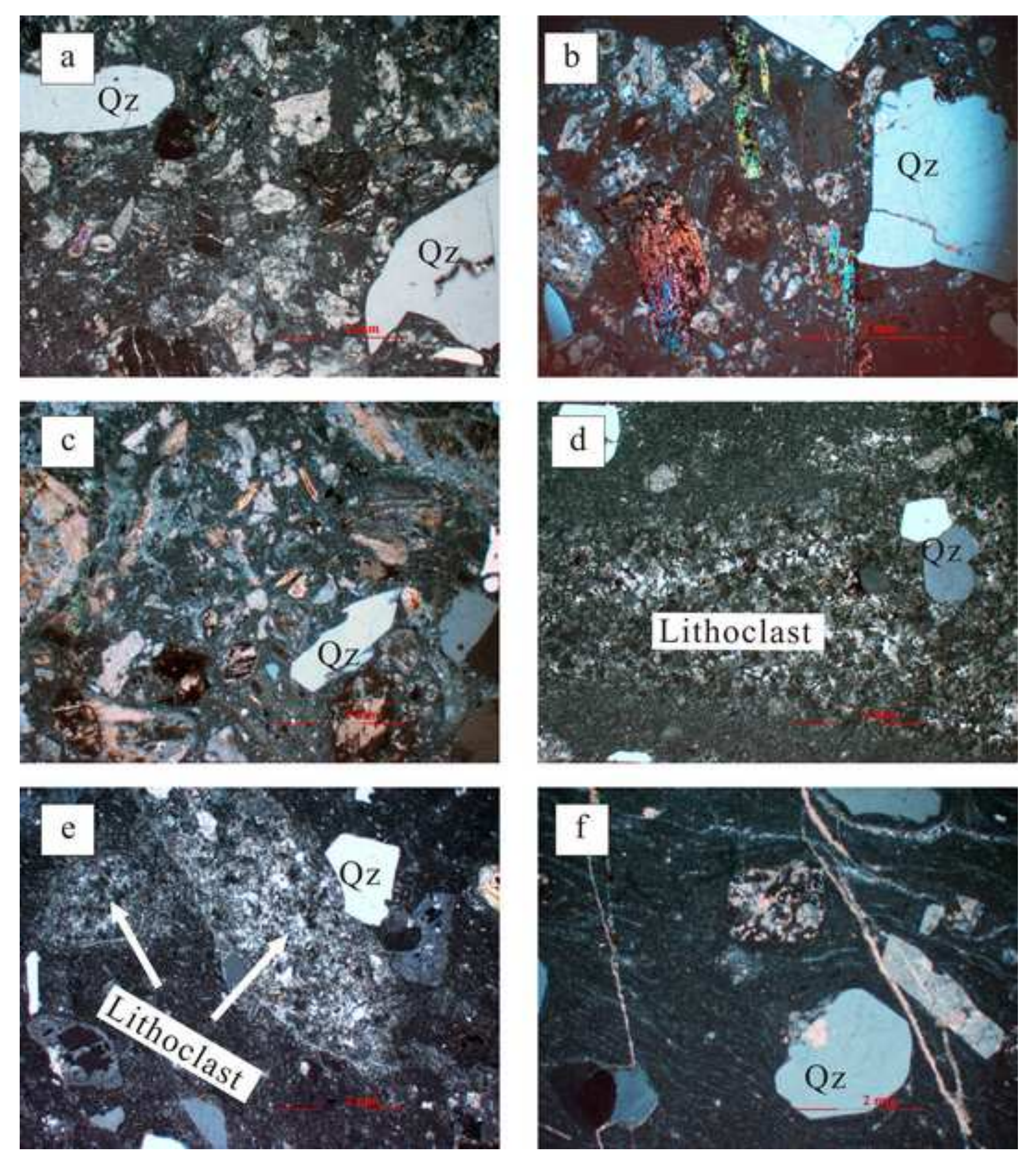


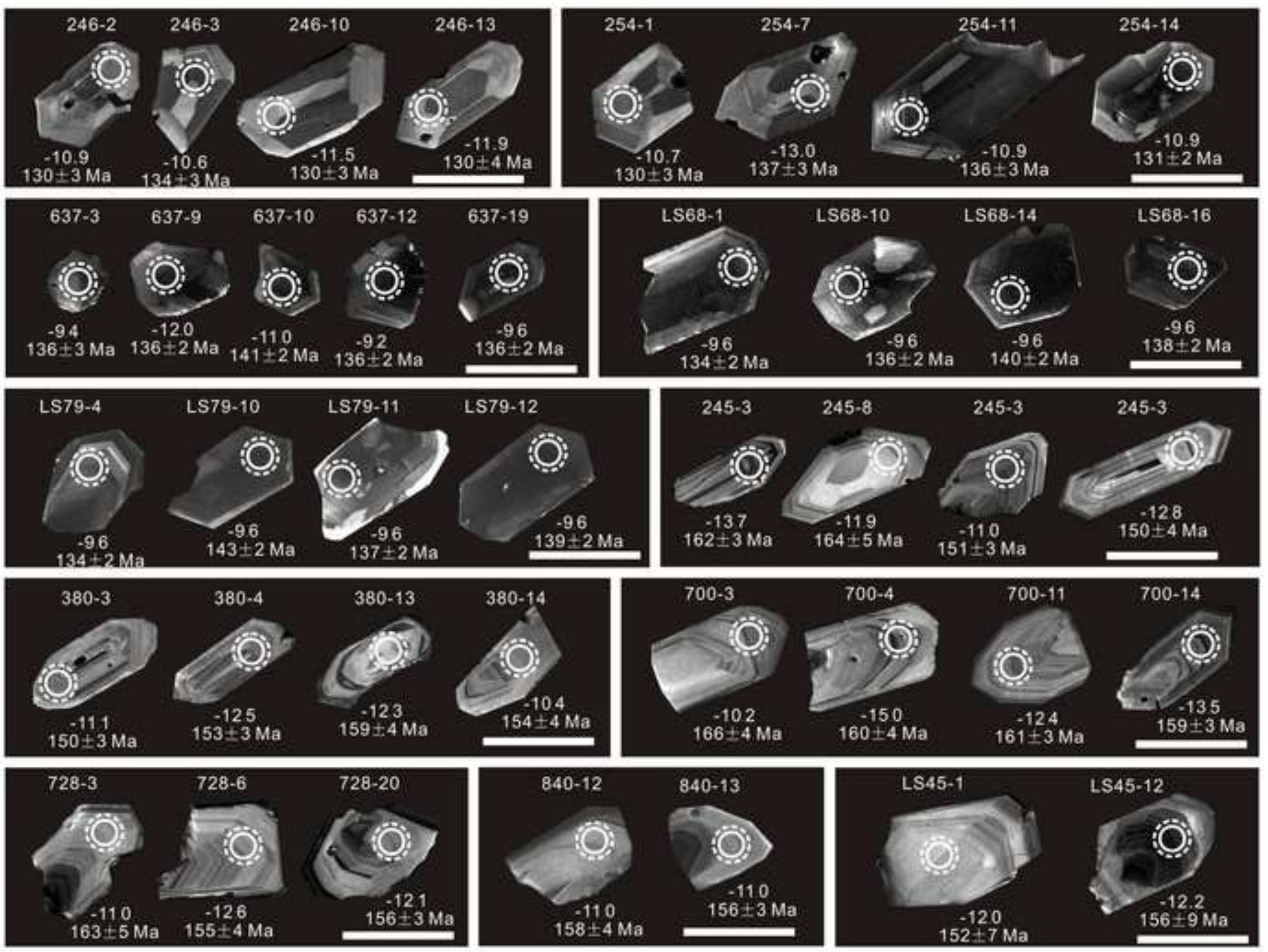


Figure 5
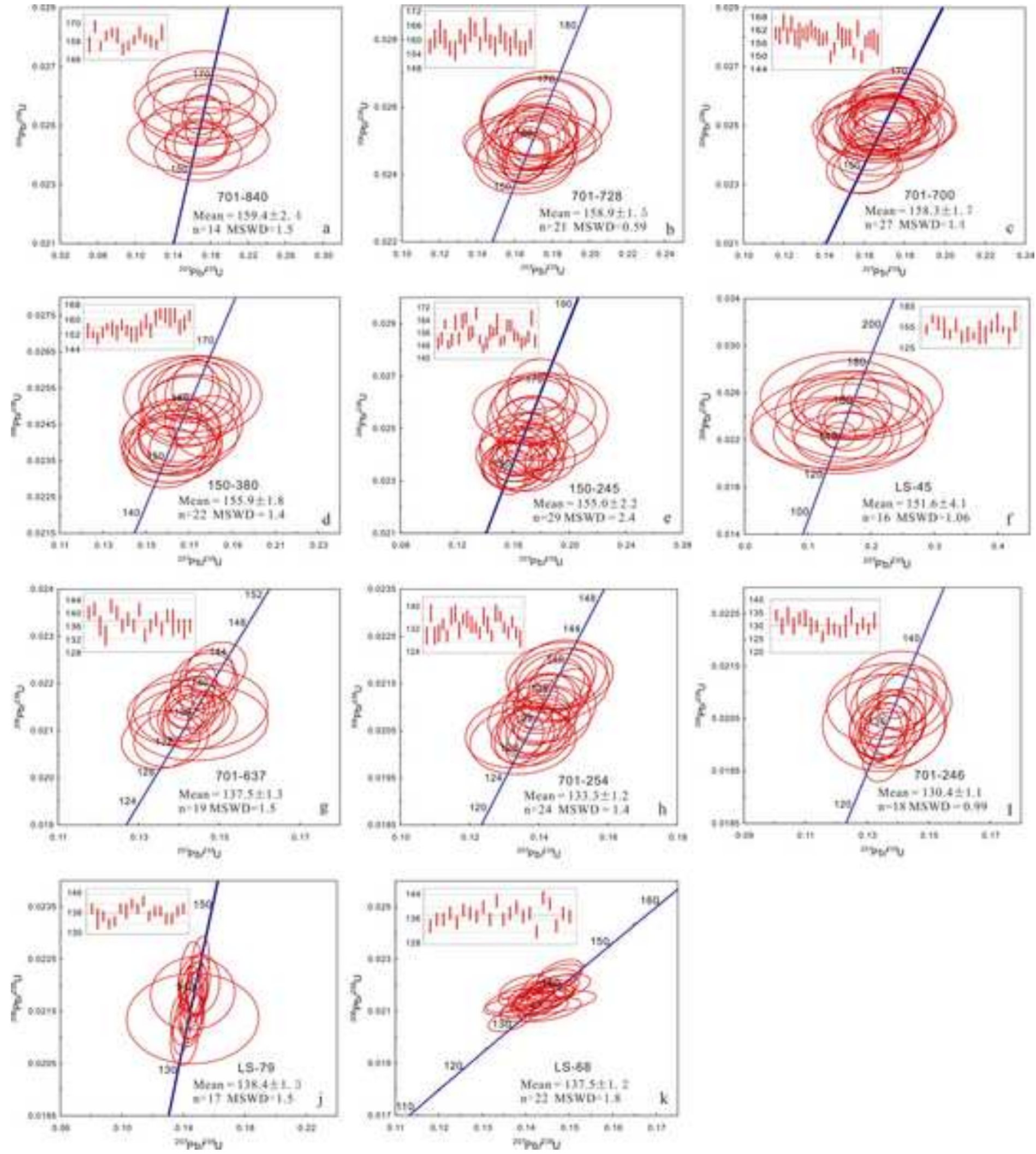


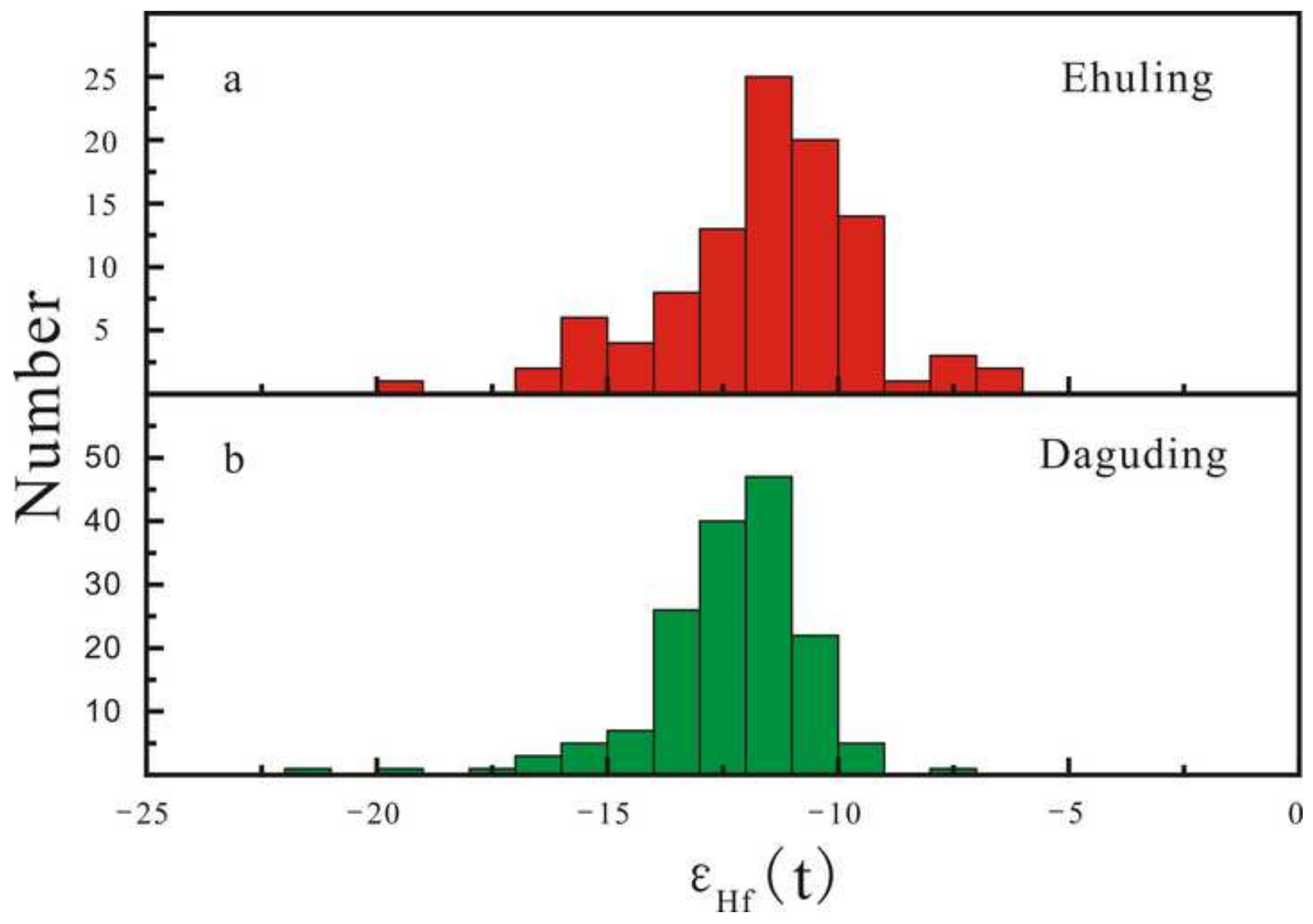




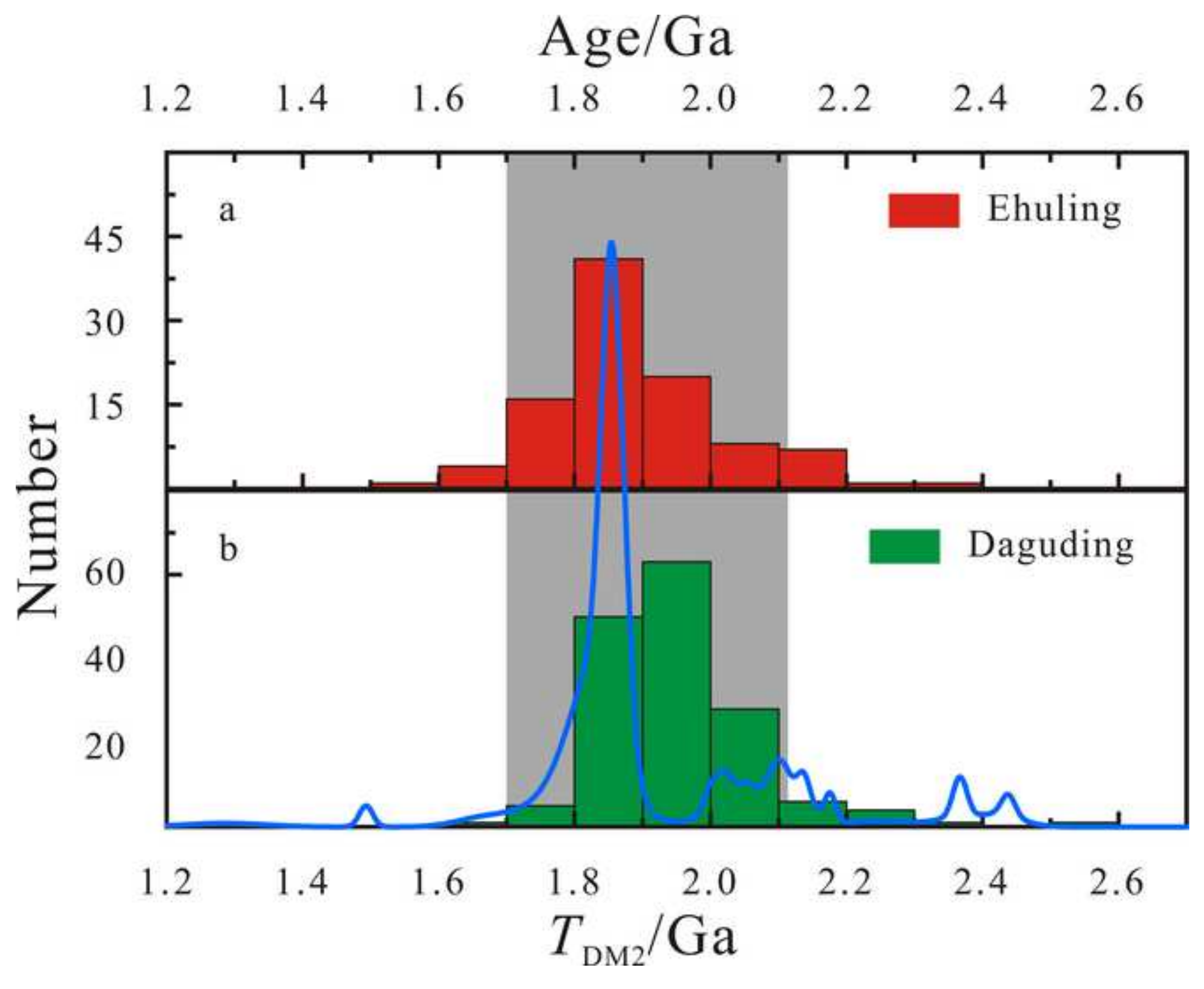

Age/Ga

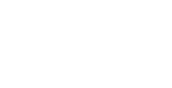

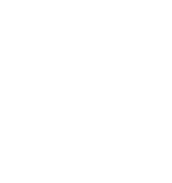




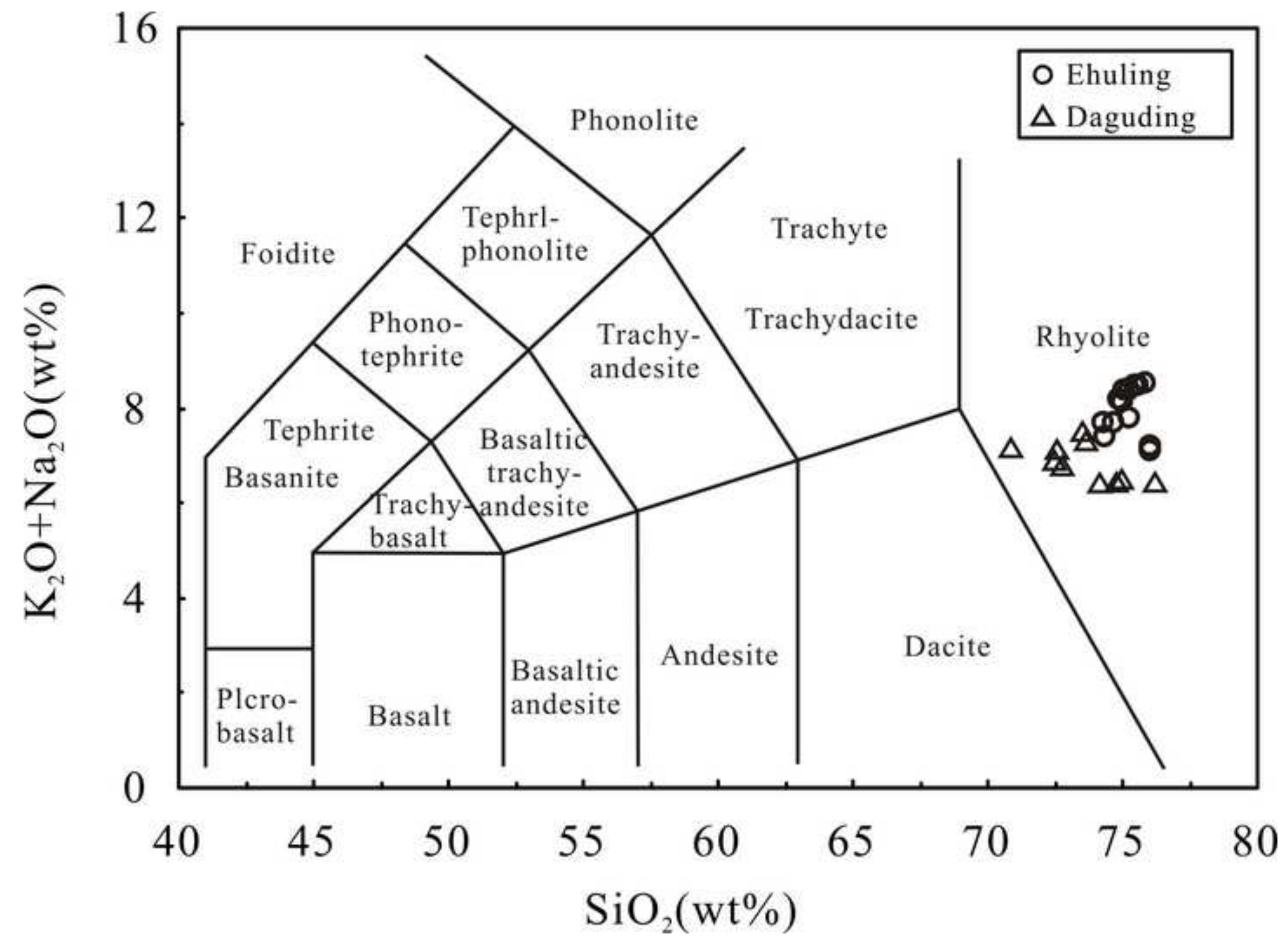


Figure 9

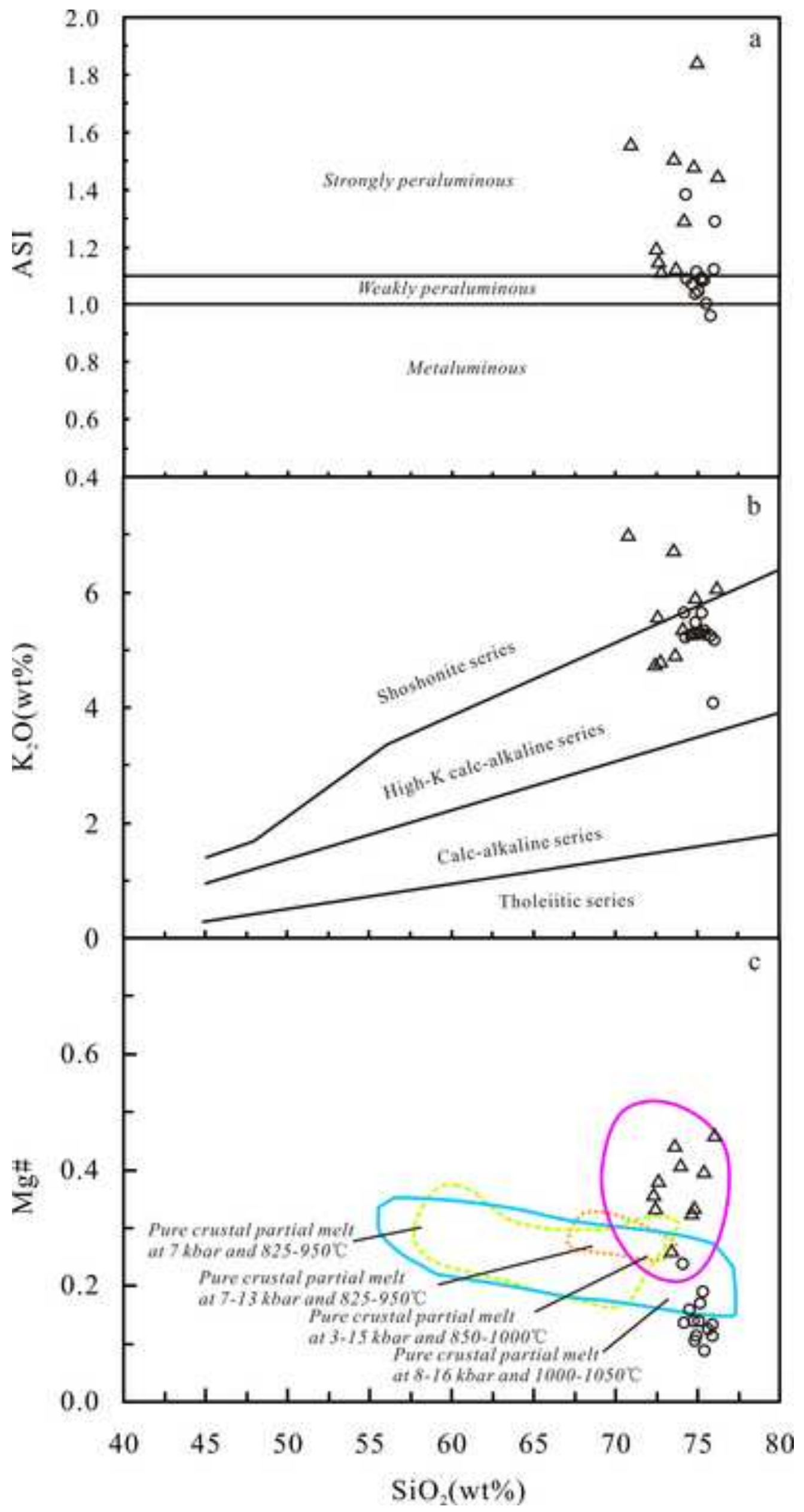




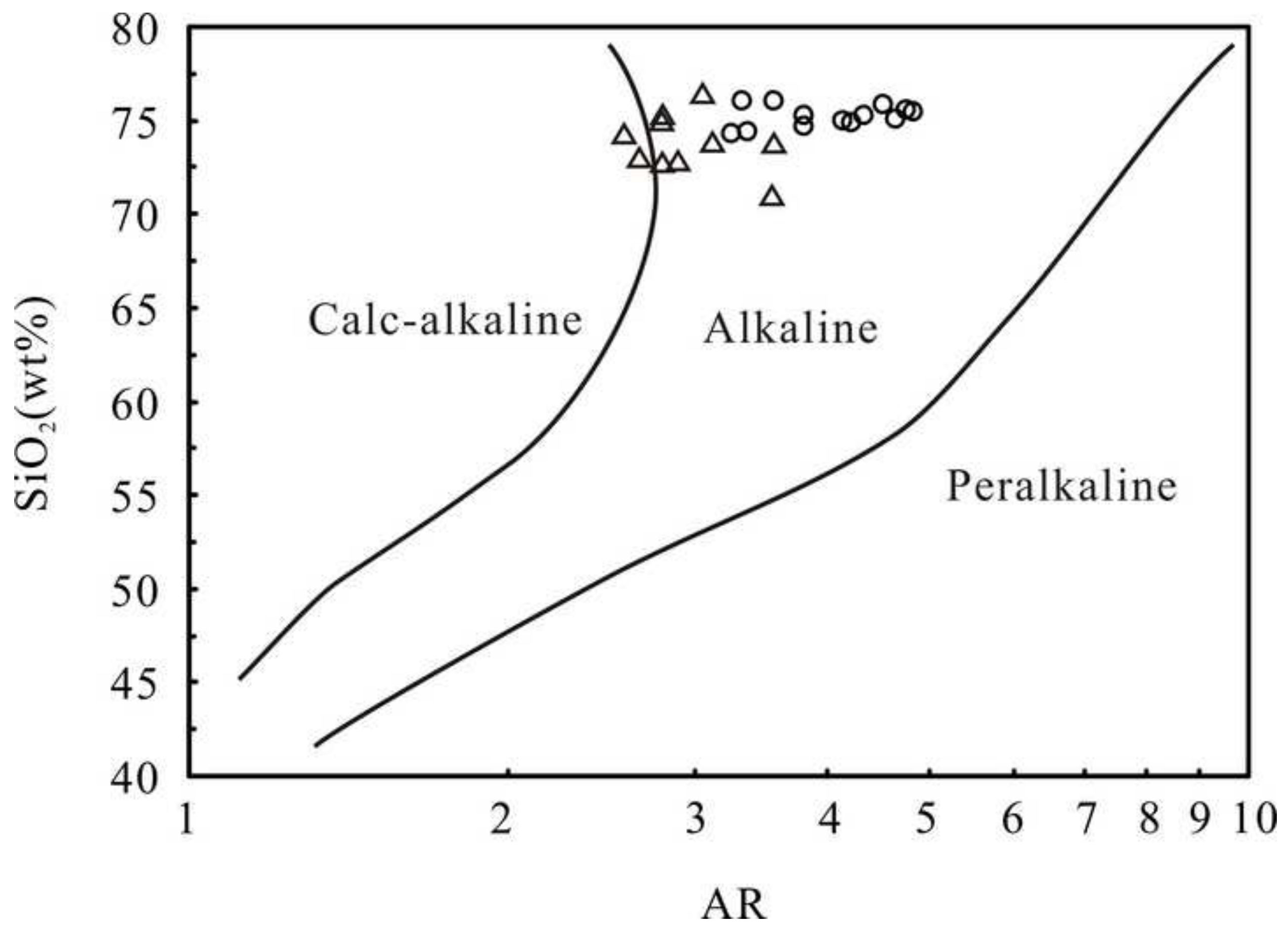



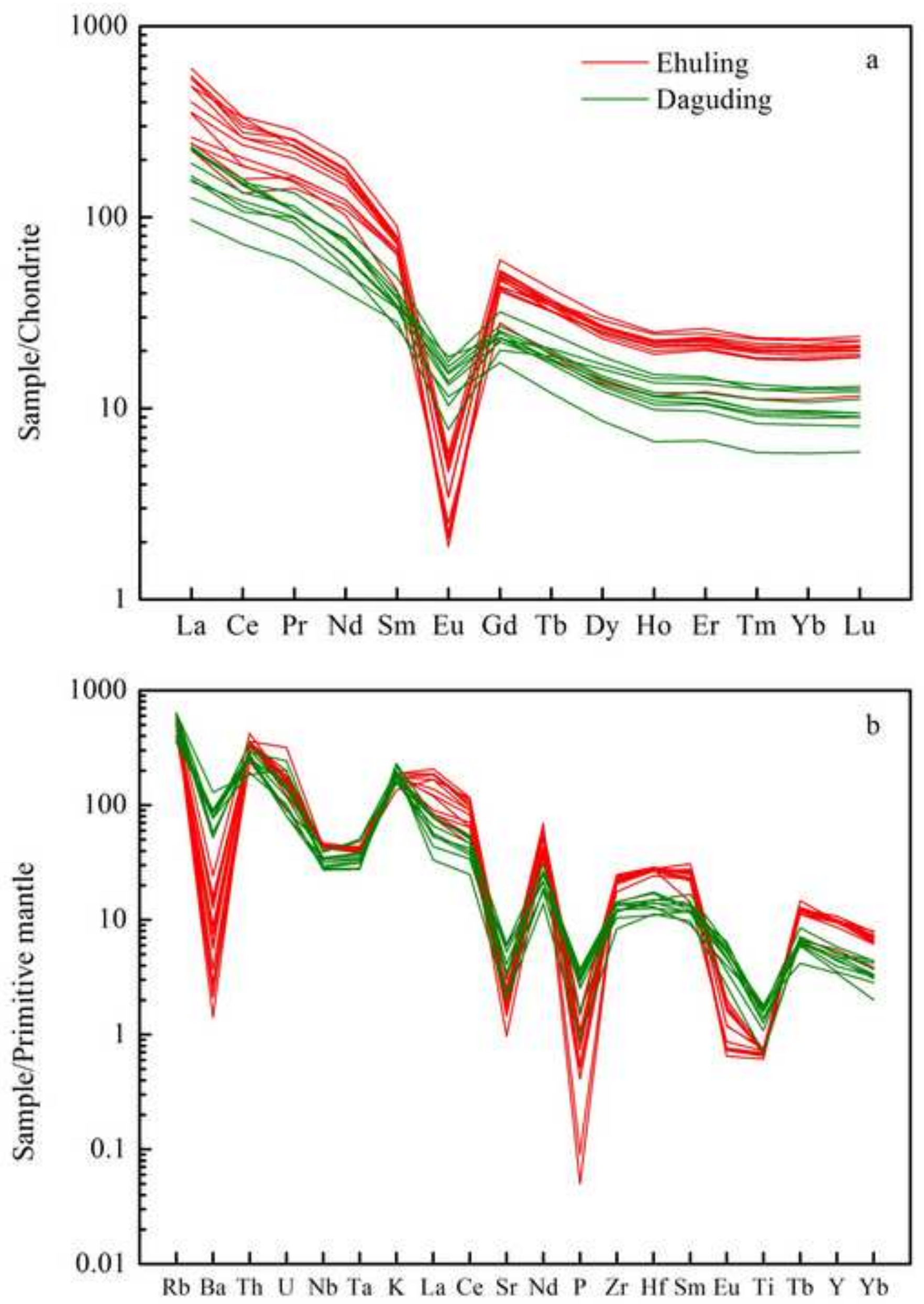

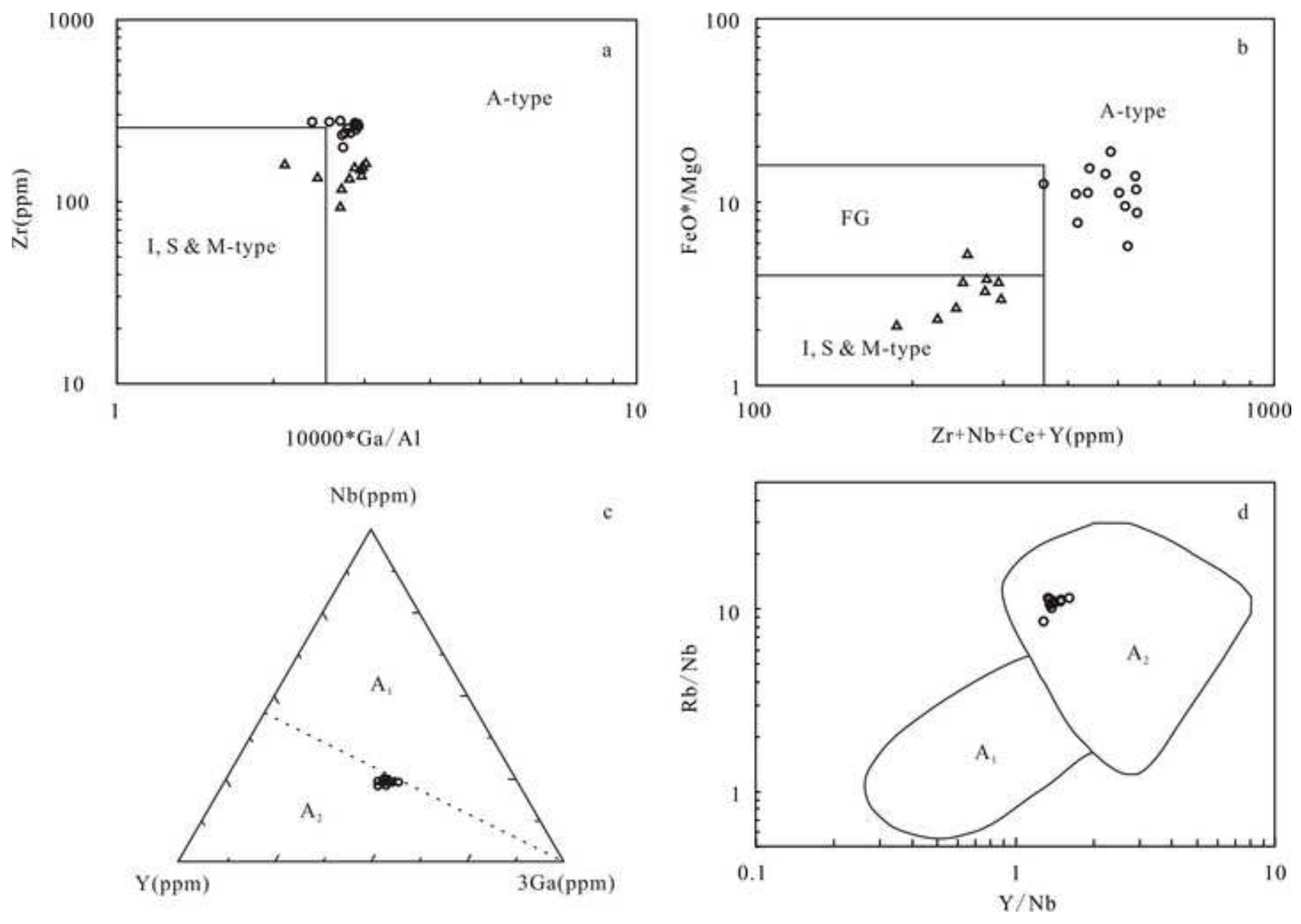


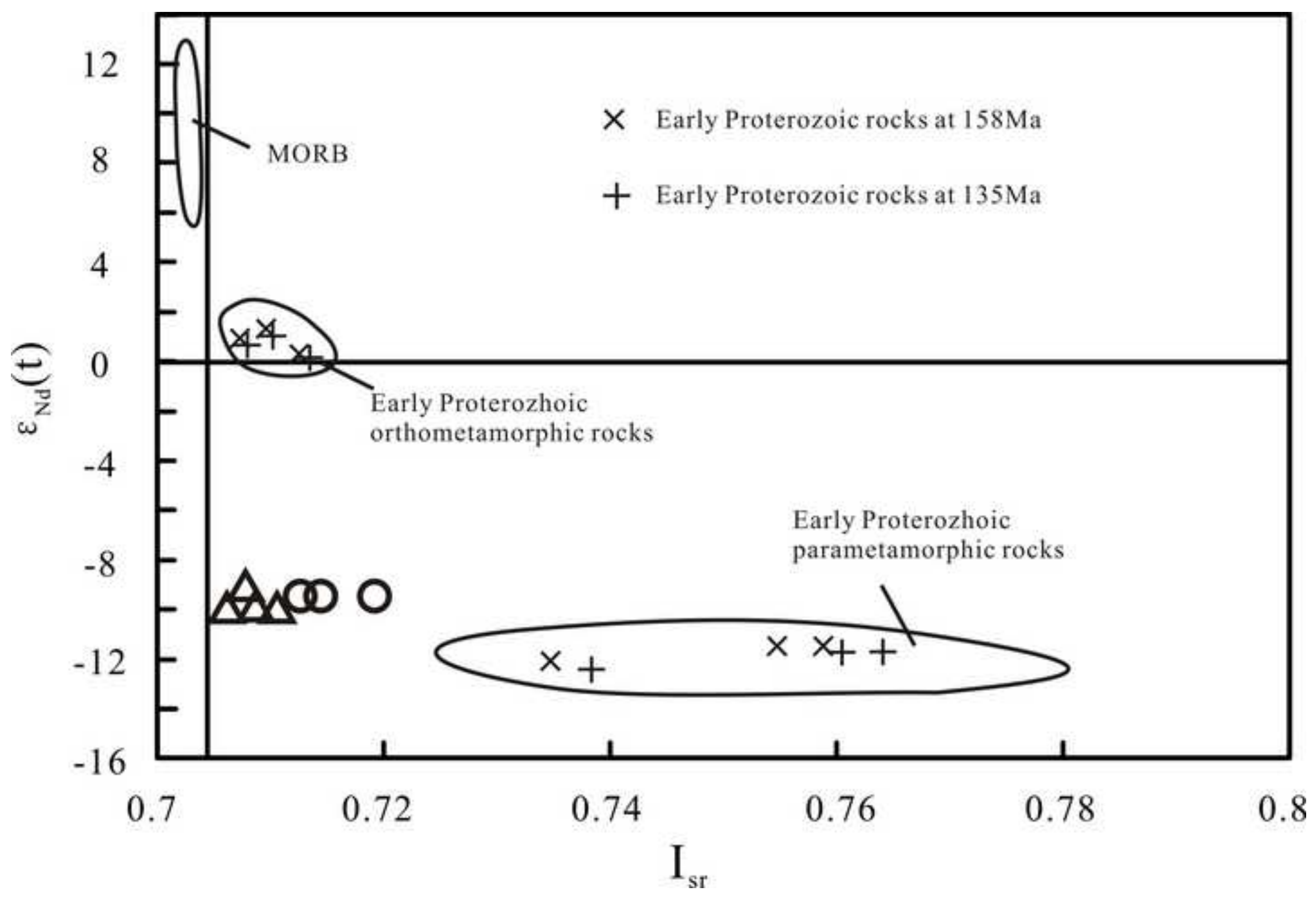




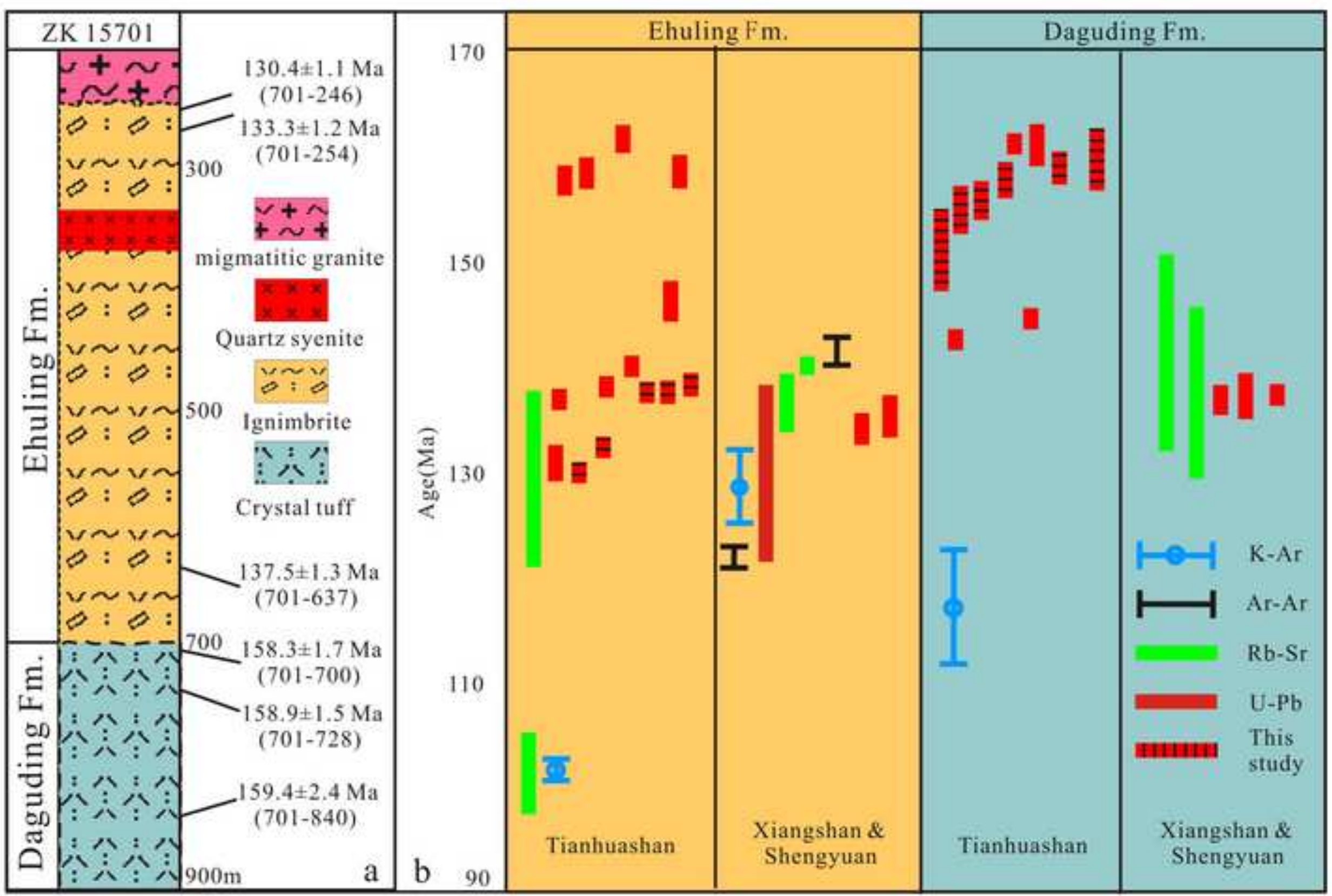




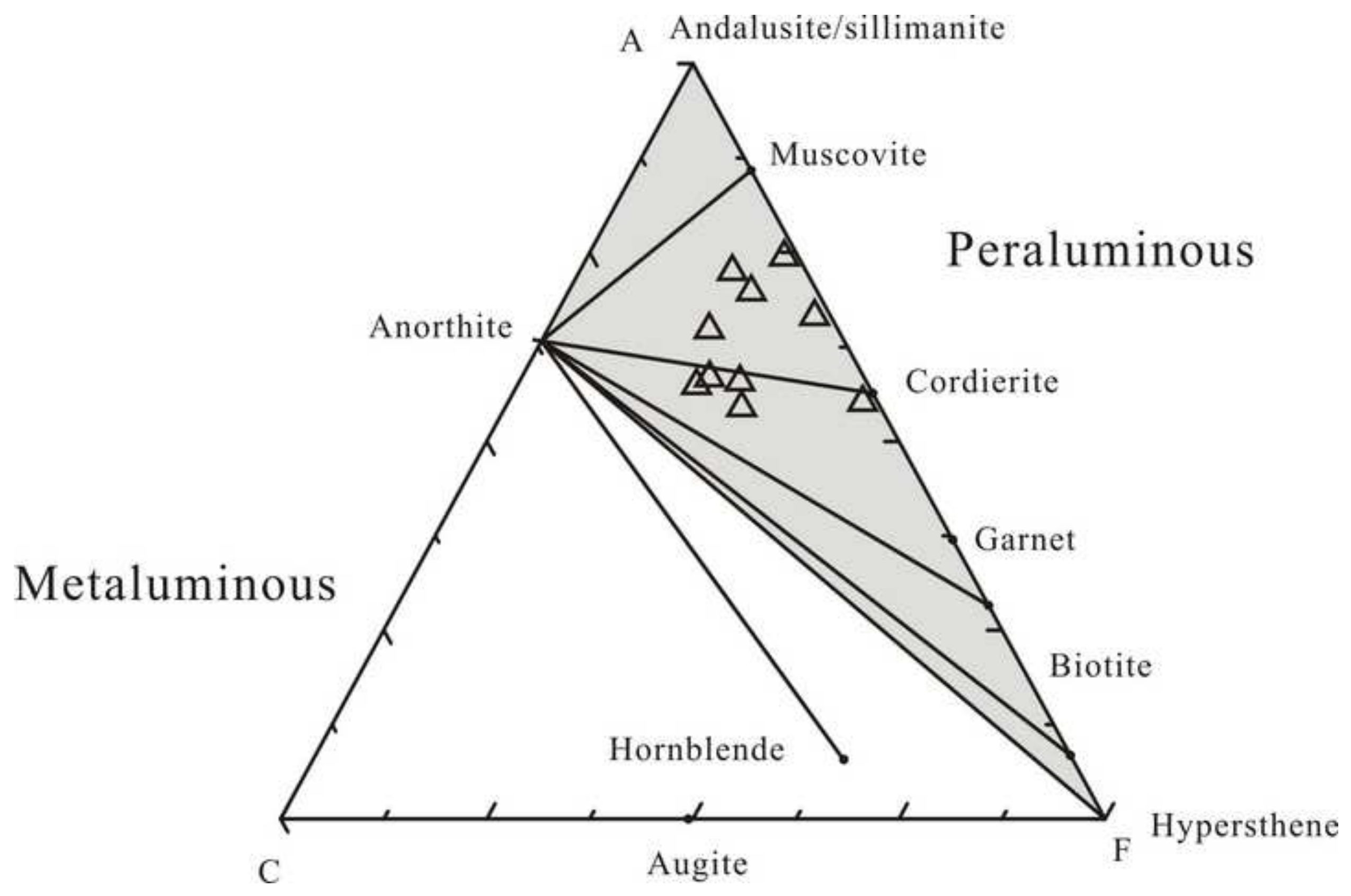

Metaluminous

C

Peraluminous 


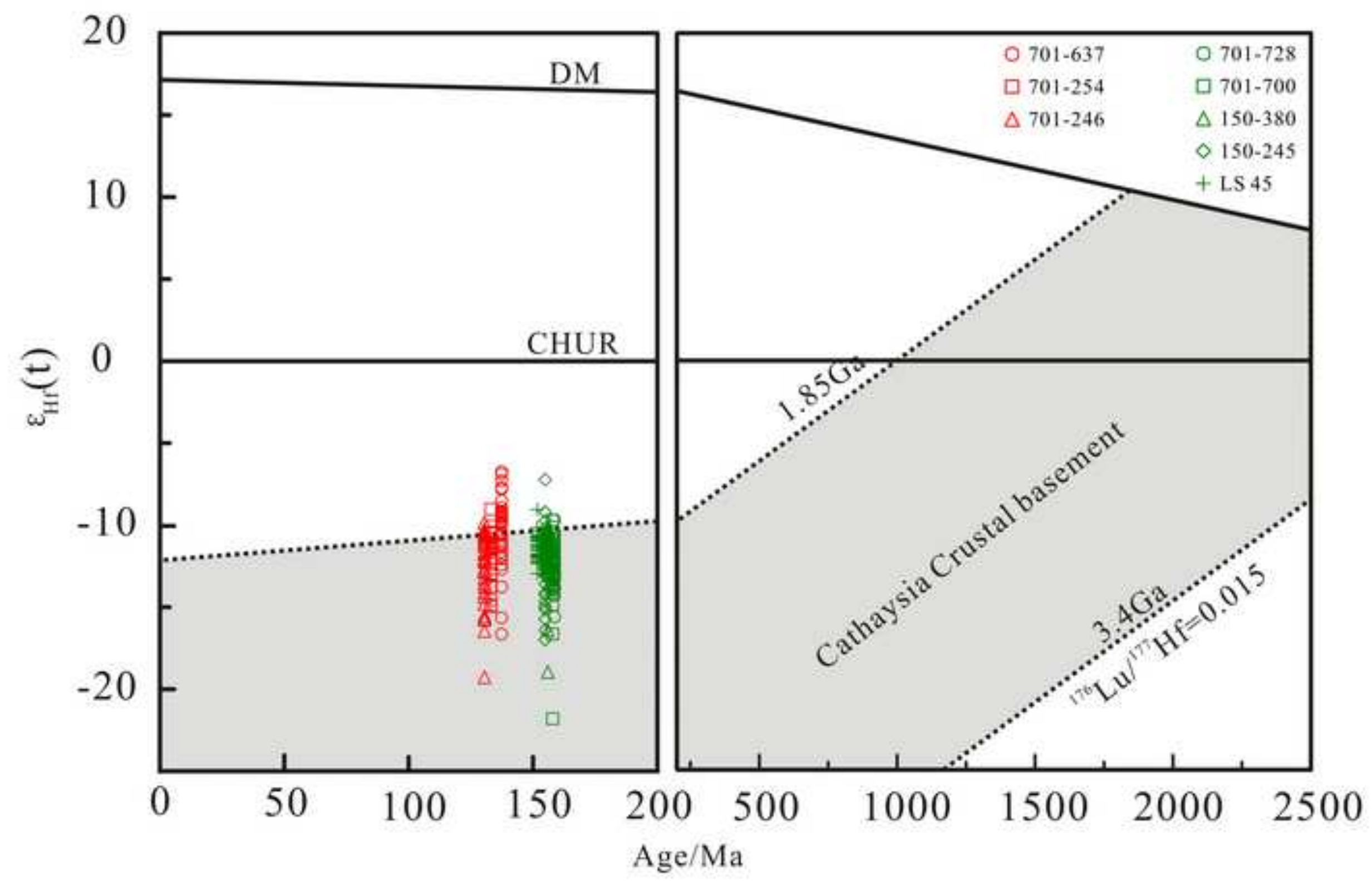



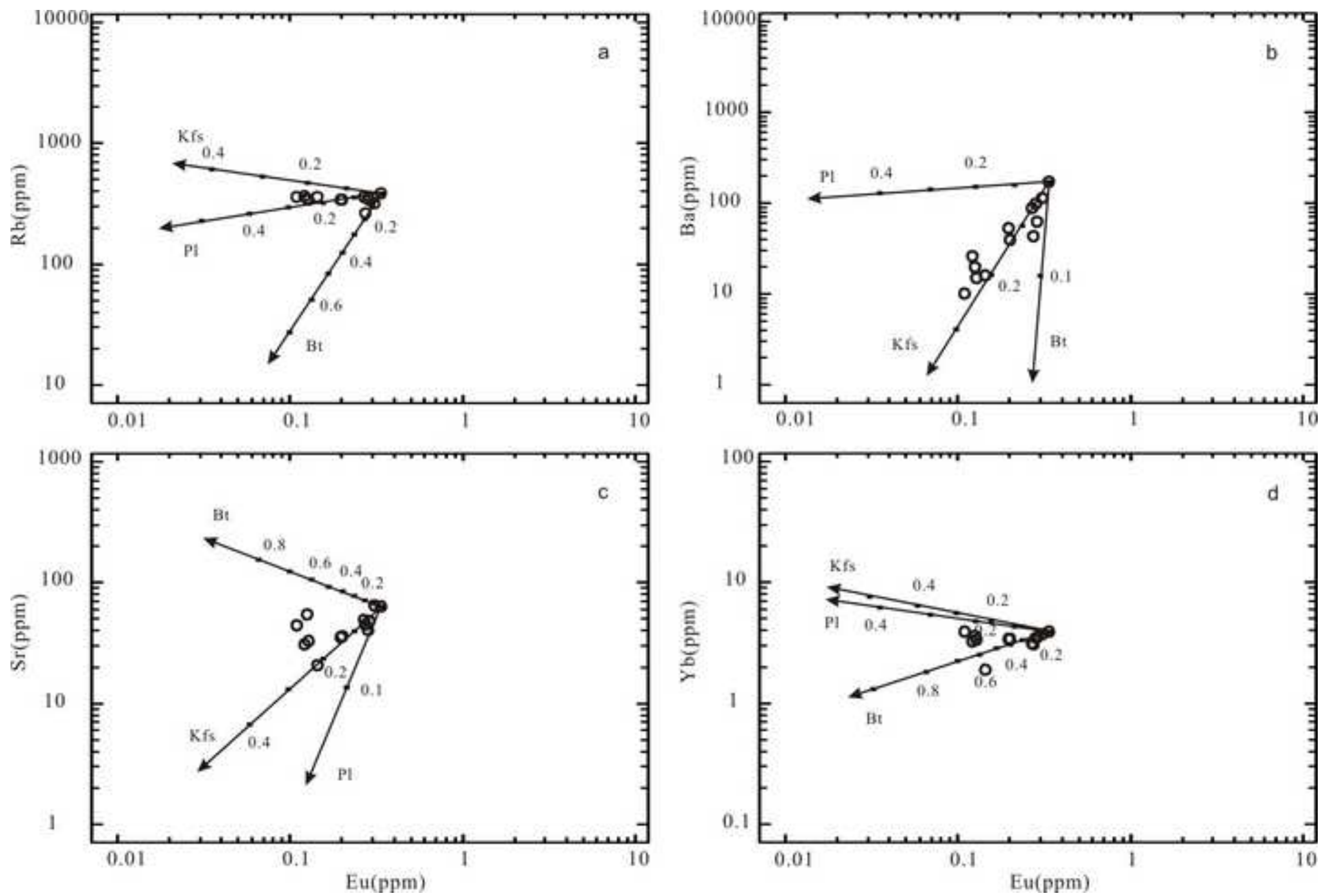

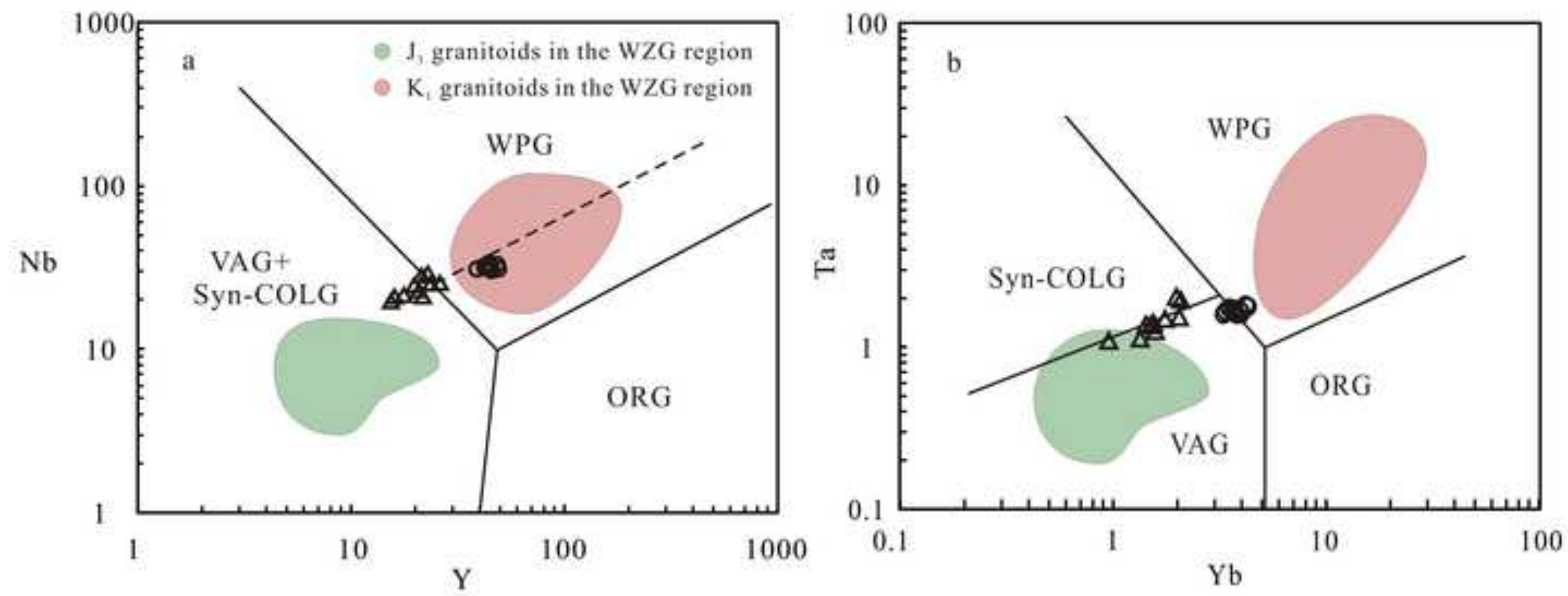

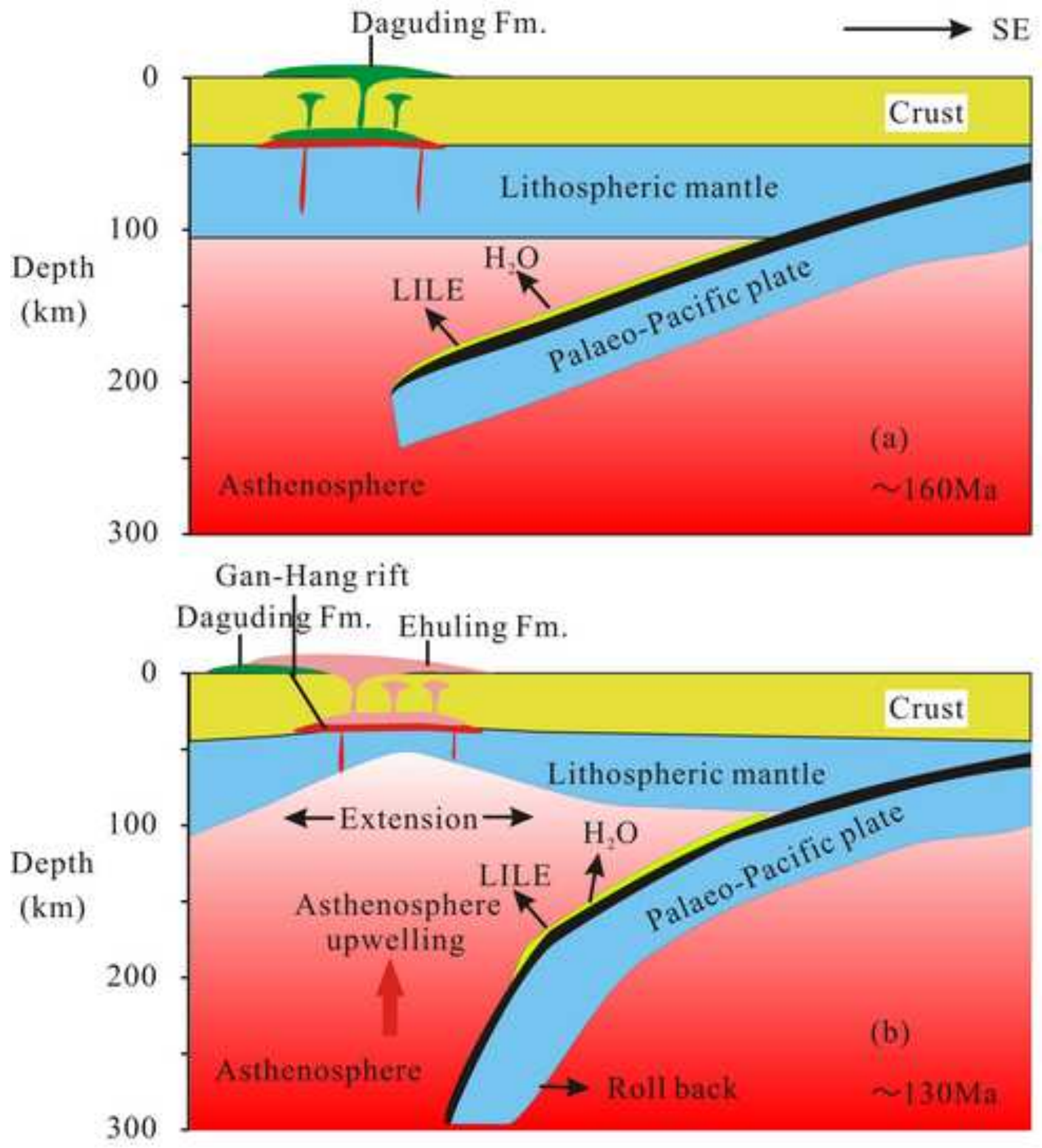
Table 1 Strata in the Lengshuikeng district (modified from the 912 Geological Team, Bureau of Geology and Mineral Resources of Jiangxi Province).

\begin{tabular}{|c|c|c|c|c|c|}
\hline System & Formation & Stage & Geological code & Thickness (m) & Major rock types \\
\hline Quaternary & & & $\mathrm{Q}$ & $0-20$ & Alluviation, slope wash \\
\hline \multirow{5}{*}{ Jurassic } & \multirow{3}{*}{ Ehuling } & Third member & $\mathrm{J}_{3} e^{3}$ & $160-1430$ & $\begin{array}{l}\text { Rhyolitic ignimbrite with } \\
\text { tuff at the bottom }\end{array}$ \\
\hline & & Second member & $\mathrm{J}_{3} e^{2}$ & $140-550$ & $\begin{array}{l}\text { Rhyolite, ignimbrite, with } \\
\text { tuffaceous } \\
\text { siltstone at the bottom }\end{array}$ \\
\hline & & First member & $\mathrm{J}_{3} e^{1}$ & $180-420$ & $\begin{array}{l}\text { Rhyolitic crystal tuff, } \\
\text { ignimbrite with tuffaceous } \\
\text { sandstone at the bottom }\end{array}$ \\
\hline & \multirow[b]{2}{*}{ Daguding } & Upper member & $\mathrm{J}_{3} d^{2}$ & $30-170$ & Andesite, tuff breccia \\
\hline & & Lower member & $\mathrm{J}_{3} d^{1}$ & $100-310$ & $\begin{array}{l}\text { Rhyolitic crystal tuff, } \\
\text { rhyolitic ignimbrite, tuff }\end{array}$ \\
\hline \multirow[b]{2}{*}{ Carboniferous } & Huanglong & & $\mathrm{C}_{2} h$ & $>170$ & Limestone \\
\hline & Zishan & & $\mathrm{C}_{1} z$ & $30-150$ & $\begin{array}{l}\text { Quartz conglomerate, } \\
\text { sandstone }\end{array}$ \\
\hline \multirow{4}{*}{ Sinian } & \multirow{3}{*}{ Laohutang } & Third member & $\mathrm{Z}_{2} l^{3}$ & $>480$ & $\begin{array}{c}\text { Biotite schist, quartz biotite } \\
\text { schist }\end{array}$ \\
\hline & & Second member & $\mathrm{Z}_{2} l^{2}$ & 410 & $\begin{array}{l}\text { K-feldspar gneiss, striped } \\
\text { migmatite }\end{array}$ \\
\hline & & First member & $\mathrm{Z}_{2} l^{1}$ & $>370$ & Quartzite, quartz schist \\
\hline & Xiafang & & $\mathrm{Z}_{2} x$ & $>500$ & $\begin{array}{l}\text { Biotite plagioclase gneiss, } \\
\text { biotite } \\
\text { quartz schist, quartzite }\end{array}$ \\
\hline
\end{tabular}


Table 2 Lithologies, pyroclast assemblages and sample locations of the Late Mesozoic volcanic rocks from Lengshuikeng district

\begin{tabular}{|c|c|c|c|c|c|}
\hline Formation & Sample no. & Colour & Lithology & Pyroclast assemblages & Location \\
\hline \multirow{5}{*}{ Ehuling } & LS68-LS76 & Flesh pink & Crystal ignimbrite & Crystals $(15 \%, \mathrm{Qz}$ and few Pl)+lithoclasts $(10 \%)+$ volcanic ash & N2754'7.86";E117º12'19.93" \\
\hline & LS77-LS83 & Gray-green & Lithic crystal ignimbrite & Crystals $(15 \%, \mathrm{Qz}$ and few pl)+lithoclasts $(10 \%)+$ volcanic ash & N275''13.28";E117²12'21.94" \\
\hline & $701-246$ & Gray-green & Rhyolitic crystal ignimbrite & Crystals $(10 \%, \mathrm{Qz}$ and few $\mathrm{Pl})+$ vitroclastic+volcanic ash & ZK15701 246m \\
\hline & $701-254$ & Gray-green & Rhyolitic crystal ignimbrite & Crystals $(10 \%, \mathrm{Qz}$ and few $\mathrm{Pl})+$ vitroclastic+volcanic ash & ZK15701 254m \\
\hline & $701-637$ & Gray-green & Crystal ignimbrite & Crystals (5\%,Qz and few Pl)+vitroclastic+volcanic ash & ZK15701637m \\
\hline \multirow{6}{*}{ Daguding } & LS45 & Gray-green & Crystal tuff & Crystals $(60 \%, \mathrm{Qz}, \mathrm{Pl}$ and few $\mathrm{Bt})+$ volcanic ash & $\mathrm{N} 27^{\circ} 54^{\prime} 43.8^{\prime \prime} ; \mathrm{E} 117^{\circ} 12^{\prime} 24.8 "$ \\
\hline & $150-245$ & Gray-green & Crystal tuff & Crystals $(50 \%, \mathrm{Qz}, \mathrm{Pl}$ and few Bt)+volcanic ash+vitroclasts & ZK15150 245m \\
\hline & $150-380$ & Gray-green & Crystal tuff & Crystals (45\%, Qz, Pl and few Bt)+volcanic ash+vitroclasts & ZK15150 380m \\
\hline & $701-700$ & Gray-green & Crystal tuff & Crystals $(60 \%, \mathrm{Qz}, \mathrm{Pl}$ and $\mathrm{Bt})+$ volcanic ash & ZK15701 700m \\
\hline & $701-728$ & Gray-green & Crystal tuff & Crystals $(55 \%, \mathrm{Qz}, \mathrm{Pl}$ and few $\mathrm{Bt})+$ volcanic ash & ZK15701 728m \\
\hline & $701-840$ & Gray-green & Crystal tuff & Crystals $(50 \%, \mathrm{Qz}, \mathrm{Pl}$ and few $\mathrm{Bt})+$ volcanic ash+vitroclasts & ZK15701 840m \\
\hline
\end{tabular}


Table 3 Major (wt.\%), trace elements (ppm) and Sr-Nd isotope compositions for volcanic rocks of the Daguding and Ehuling Fm.

\begin{tabular}{|c|c|c|c|c|c|c|c|c|c|c|c|c|c|}
\hline Formation & & & & & & & huling Fm. & & & & & & \\
\hline Sample & $701-246$ & $701-251$ & $701-254$ & $701-258$ & $701-270$ & $701-286$ & $701-293$ & $701-637$ & $701-645$ & $701-656$ & $701-662$ & $701-672$ & $701-684$ \\
\hline $\mathrm{SiO}_{2}$ & 74.34 & 74.27 & 76.06 & 75.29 & 76.03 & 74.68 & 74.97 & 75.57 & 75.07 & 75.23 & 75.44 & 75.83 & 74.86 \\
\hline $\mathrm{TiO}_{2}$ & 0.12 & 0.11 & 0.13 & 0.14 & 0.13 & 0.15 & 0.14 & 0.12 & 0.1 & 0.12 & 0.09 & 0.09 & 0.09 \\
\hline $\mathrm{Al}_{2} \mathrm{O}_{3}$ & 12.38 & 14.1 & 12.19 & 12.34 & 12.46 & 12.16 & 12.65 & 12.24 & 12.38 & 12.79 & 12.57 & 12.38 & 12.38 \\
\hline $\mathrm{Fe}_{2} \mathrm{O}_{3} \mathrm{~T}$ & 2.5 & 1.6 & 1.93 & 1.75 & 1.69 & 2.41 & 2.03 & 2.08 & 1.88 & 1.87 & 1.7 & 1.67 & 1.96 \\
\hline $\mathrm{MnO}$ & 0.1 & 0.03 & 0.04 & 0.06 & 0.07 & 0.11 & 0.05 & 0.1 & 0.07 & 0.06 & 0.04 & 0.08 & 0.1 \\
\hline $\mathrm{MgO}$ & 0.2 & 0.25 & 0.15 & 0.18 & 0.11 & 0.23 & 0.12 & 0.1 & 0.12 & 0.15 & 0.2 & 0.12 & 0.16 \\
\hline $\mathrm{CaO}$ & 1.21 & 0.4 & 0.41 & 0.95 & 0.88 & 0.95 & 0.61 & 0.71 & 0.59 & 0.57 & 0.35 & 0.99 & 0.82 \\
\hline $\mathrm{Na}_{2} \mathrm{O}$ & 2.17 & 2.06 & 1.91 & 2.13 & 3.11 & 2.41 & 2.65 & 3.2 & 3.09 & 3.09 & 3.17 & 3.31 & 2.88 \\
\hline $\mathrm{K}_{2} \mathrm{O}$ & 5.2 & 5.63 & 5.17 & 5.63 & 4.07 & 5.25 & 5.46 & 5.25 & 5.28 & 5.27 & 5.32 & 5.22 & 5.27 \\
\hline $\mathrm{P}_{2} \mathrm{O}_{5}$ & 0.01 & 0.02 & 0.03 & 0 & 0.02 & 0.02 & 0.01 & 0 & 0.03 & 0.01 & 0.01 & 0.02 & 0.02 \\
\hline LOI & 1.73 & 1.13 & 1.16 & 1.52 & 1.47 & 1.34 & 1.02 & 0.55 & 0.64 & 0.77 & 0.73 & 1.04 & 0.97 \\
\hline Total & 99.96 & 99.61 & 99.19 & 99.99 & 100.03 & 99.72 & 99.71 & 99.91 & 99.25 & 99.93 & 99.63 & 100.75 & 99.51 \\
\hline A.R & 3.37 & 3.26 & 3.57 & 3.81 & 3.33 & 3.81 & 4.15 & 4.76 & 4.64 & 4.34 & 4.83 & 4.52 & 4.23 \\
\hline ASI & 1.09 & 1.38 & 1.29 & 1.09 & 1.12 & 1.07 & 1.11 & 1 & 1.04 & 1.08 & 1.08 & 0.96 & 1.04 \\
\hline $\mathrm{Mg} \#$ & 0.14 & 0.24 & 0.13 & 0.17 & 0.11 & 0.16 & 0.1 & 0.09 & 0.11 & 0.14 & 0.19 & 0.12 & 0.14 \\
\hline $\mathrm{V}$ & 1.52 & 1.11 & 1.17 & 0.61 & 1.3 & 0.99 & 0.98 & 1.36 & 0.89 & 0.54 & 0.41 & 0.43 & 0.3 \\
\hline $\mathrm{Cr}$ & 25.49 & 12.07 & 8.75 & 4.78 & 12.42 & 9.13 & 11.03 & 23.46 & 10.57 & 14.73 & 21.2 & 20.62 & 14.67 \\
\hline $\mathrm{Ni}$ & 4.9 & 1.66 & 1.46 & 1.09 & 2.22 & 1.96 & 2.22 & 4.74 & 1.84 & 2.59 & 3.53 & 3.67 & 2.53 \\
\hline $\mathrm{Ga}$ & 18.84 & 17.75 & 17.44 & 18.78 & 19.23 & 18.8 & 17.19 & 18.74 & 18.28 & 19.1 & 18.1 & 17.9 & 18.01 \\
\hline $\mathrm{Rb}$ & 315.6 & 342.5 & 358.4 & 383.3 & 259.9 & 336.0 & 358.8 & 337.8 & 341.4 & 336.1 & 364.7 & 357.8 & 343.3 \\
\hline $\mathrm{Sr}$ & 64.62 & 40.02 & 48.54 & 63.35 & 44.99 & 47.46 & 20.45 & 35.4 & 34.9 & 32.79 & 30.78 & 43.61 & 53.63 \\
\hline $\mathrm{Y}$ & 43.68 & 45.13 & 43.36 & 44.57 & 39.29 & 45.76 & 25.15 & 44.14 & 44.48 & 42.81 & 43 & 48.75 & 49.16 \\
\hline
\end{tabular}




\begin{tabular}{|c|c|c|c|c|c|c|c|c|c|c|c|c|c|}
\hline $\mathrm{Zr}$ & 269 & 275 & 276 & 260 & 267 & 259 & 271 & 248 & 252 & 239 & 230 & 197 & 238 \\
\hline $\mathrm{Nb}$ & 31.65 & 31.86 & 31.98 & 33.27 & 30.44 & 30.24 & 31.09 & 32.39 & 31.3 & 31.25 & 31.67 & 32.61 & 30.33 \\
\hline $\mathrm{Ba}$ & 111.1 & 98.3 & 87.76 & 169 & 42.55 & 61.2 & 15.87 & 39.17 & 52.22 & 14.76 & 25.92 & 9.92 & 19.31 \\
\hline $\mathrm{La}$ & 114.8 & 129.6 & 129.35 & 141.77 & 114.8 & 125.2 & 82.4 & 94.77 & 83.81 & 62.13 & 57.15 & 53.24 & 57.83 \\
\hline $\mathrm{Ce}$ & 159.1 & 170.1 & 190.2 & 205.8 & 203.3 & 181.2 & 114.1 & 159.8 & 146.3 & 125.1 & 113.2 & 81.79 & 96.83 \\
\hline $\operatorname{Pr}$ & 22.59 & 24.43 & 23.88 & 27.12 & 22.16 & 24.26 & 14.52 & 20.72 & 19.3 & 15.62 & 14.79 & 13.46 & 15.42 \\
\hline $\mathrm{Nd}$ & 77.95 & 83.15 & 81.57 & 93.83 & 76.66 & 83.88 & 47.93 & 73.36 & 69.01 & 57.32 & 54.62 & 51.12 & 57.61 \\
\hline $\mathrm{Sm}$ & 11.44 & 11.78 & 11.47 & 13.69 & 11.04 & 12.15 & 6.38 & 11.5 & 11.12 & 9.97 & 9.71 & 10.01 & 10.37 \\
\hline $\mathrm{Eu}$ & 0.31 & 0.29 & 0.27 & 0.34 & 0.27 & 0.29 & 0.15 & 0.2 & 0.2 & 0.13 & 0.12 & 0.11 & 0.13 \\
\hline $\mathrm{Gd}$ & 10.16 & 10.6 & 10.35 & 12.28 & 9.75 & 10.83 & 5.77 & 9.97 & 9.61 & 8.66 & 8.42 & 8.78 & 8.93 \\
\hline $\mathrm{Tb}$ & 1.34 & 1.35 & 1.28 & 1.58 & 1.21 & 1.39 & 0.71 & 1.33 & 1.3 & 1.22 & 1.2 & 1.34 & 1.29 \\
\hline Dy & 6.75 & 6.78 & 6.13 & 7.77 & 5.9 & 6.87 & 3.47 & 6.75 & 6.62 & 6.42 & 6.31 & 7.34 & 6.86 \\
\hline Но & 1.27 & 1.25 & 1.13 & 1.42 & 1.09 & 1.27 & 0.65 & 1.25 & 1.24 & 1.2 & 1.19 & 1.39 & 1.29 \\
\hline $\mathrm{Er}$ & 3.91 & 3.79 & 3.42 & 4.32 & 3.34 & 3.84 & 2.02 & 3.74 & 3.69 & 3.57 & 3.51 & 4.08 & 3.83 \\
\hline $\mathrm{Tm}$ & 0.56 & 0.52 & 0.47 & 0.6 & 0.46 & 0.54 & 0.29 & 0.52 & 0.52 & 0.51 & 0.5 & 0.59 & 0.54 \\
\hline $\mathrm{Yb}$ & 3.66 & 3.43 & 3.09 & 3.92 & 3.04 & 3.52 & 1.9 & 3.4 & 3.38 & 3.34 & 3.21 & 3.86 & 3.57 \\
\hline $\mathrm{Lu}$ & 0.57 & 0.53 & 0.47 & 0.6 & 0.47 & 0.54 & 0.3 & 0.51 & 0.51 & 0.51 & 0.49 & 0.58 & 0.54 \\
\hline $\mathrm{Hf}$ & 8.58 & 8.77 & 8.89 & 8.56 & 8.49 & 8.36 & 8.49 & 8.28 & 8.48 & 8.28 & 8.22 & 7.48 & 8.34 \\
\hline $\mathrm{Ta}$ & 1.6 & 1.63 & 1.64 & 1.75 & 1.58 & 1.57 & 1.61 & 1.66 & 1.65 & 1.65 & 1.71 & 1.78 & 1.68 \\
\hline $\mathrm{Pb}$ & 32.58 & 26.55 & 16.1 & 36.36 & 19.33 & 35.5 & 24.4 & 44.72 & 50.39 & 49.3 & 45.75 & 46.41 & 41.46 \\
\hline Th & 27.43 & 28.8 & 29.88 & 35.76 & 30.52 & 29.48 & 20.31 & 30.39 & 29.21 & 29.99 & 27.39 & 29.31 & 28.45 \\
\hline $\mathrm{U}$ & 3.16 & 2.85 & 2.58 & 3.25 & 6.7 & 3.14 & 1.89 & 3.8 & 3.58 & 4.16 & 3.49 & 3.61 & 3.4 \\
\hline$\Sigma \mathrm{REE}$ & 414.45 & 447.59 & 463.06 & 515.03 & 453.57 & 455.77 & 280.54 & 387.81 & 356.61 & 295.67 & 274.4 & 237.69 & 265.04 \\
\hline$(\mathrm{La} / \mathrm{Yb})_{\mathrm{N}}$ & 22.48 & 27.09 & 29.98 & 25.92 & 27.08 & 25.51 & 31.18 & 20 & 17.78 & 13.35 & 12.77 & 9.9 & 11.6 \\
\hline $\mathrm{Eu} / \mathrm{Eu}^{*}$ & 0.09 & 0.08 & 0.08 & 0.08 & 0.08 & 0.08 & 0.07 & 0.06 & 0.06 & 0.04 & 0.04 & 0.04 & 0.04 \\
\hline${ }^{87} \mathrm{Rb} /{ }^{86} \mathrm{Sr}$ & 14.131 & 24.765 & 21.366 & 17.507 & 16.718 & 20.488 & 50.766 & 27.608 & 28.309 & 29.664 & 34.280 & 23.737 & 18.525 \\
\hline
\end{tabular}




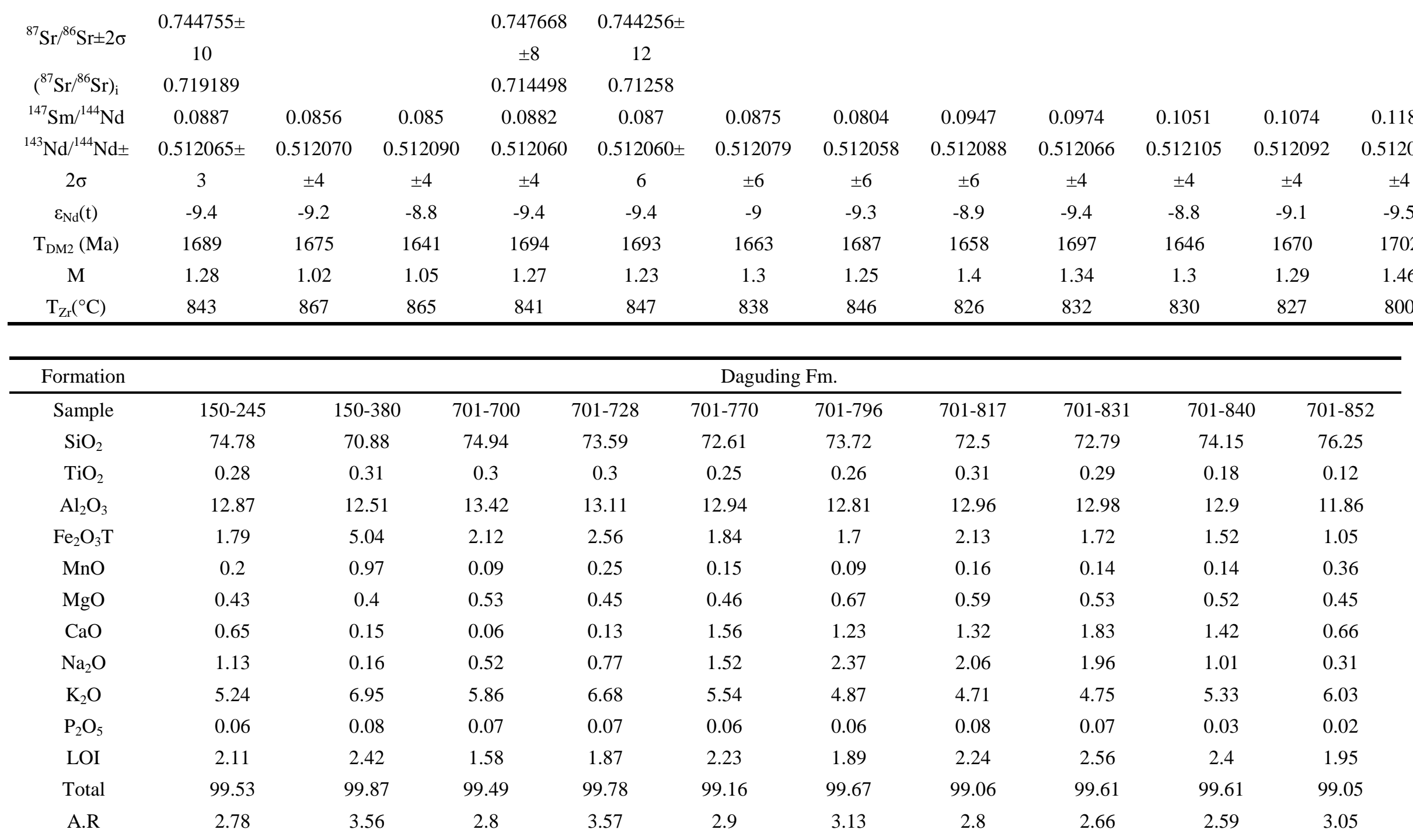




\begin{tabular}{|c|c|c|c|c|c|c|c|c|c|c|}
\hline ASI & 1.48 & 1.55 & 1.84 & 1.5 & 1.14 & 1.12 & 1.19 & 1.11 & 1.29 & 1.44 \\
\hline Mg\# & 0.32 & 0.14 & 0.33 & 0.26 & 0.33 & 0.44 & 0.35 & 0.38 & 0.4 & 0.46 \\
\hline $\mathrm{V}$ & 19.2 & 31.96 & 23.96 & 32.83 & 27.97 & 27.17 & 28.7 & 26.2 & 20.73 & 13.22 \\
\hline $\mathrm{Cr}$ & 8.99 & 12.64 & 11.21 & 34.77 & 11.17 & 9.99 & 26.4 & 20.56 & 32.86 & 8.26 \\
\hline $\mathrm{Ni}$ & 2.0 & 5.78 & 2.53 & 6.48 & 2.8 & 2.36 & 6.04 & 4.24 & 6.95 & 1.42 \\
\hline $\mathrm{Ga}$ & 16.59 & 19.97 & 14.99 & 19.95 & 20.26 & 18.36 & 20.3 & 20.52 & 19.2 & 16.93 \\
\hline $\mathrm{Rb}$ & 284.4 & 402.3 & 395.6 & 406.4 & 254.0 & 220.4 & 229.2 & 245.7 & 335.3 & 373.8 \\
\hline $\mathrm{Sr}$ & 69.2 & 72.51 & 67.82 & 46.72 & 111.1 & 124.3 & 86.54 & 128.9 & 70.51 & 43.86 \\
\hline $\mathrm{Y}$ & 23.66 & 16.08 & 20.67 & 15.58 & 17.9 & 21.84 & 20.04 & 26.36 & 23.08 & 21.77 \\
\hline $\mathrm{Zr}$ & 134 & 161 & 159 & 151 & 138 & 116 & 150 & 154 & 132 & 93.68 \\
\hline $\mathrm{Nb}$ & 24.71 & 20.1 & 22.37 & 19.4 & 20.84 & 20.54 & 23.91 & 24.82 & 28.43 & 27.77 \\
\hline $\mathrm{Ba}$ & 619 & 904 & 400 & 539 & 548 & 636 & 599 & 537 & 363 & 366 \\
\hline $\mathrm{La}$ & 54.1 & 55.44 & 52.91 & 39.04 & 36.53 & 37.47 & 45.43 & 53.4 & 29.98 & 22.92 \\
\hline $\mathrm{Ce}$ & 96.29 & 89.92 & 92.1 & 69.49 & 74.45 & 65.49 & 82.69 & 92.88 & 60.1 & 44.14 \\
\hline $\operatorname{Pr}$ & 10.27 & 10.23 & 10.28 & 8.88 & 9.53 & 9.45 & 10.86 & 12.79 & 7.19 & 5.55 \\
\hline $\mathrm{Nd}$ & 36.04 & 35.27 & 36.15 & 25.55 & 28.82 & 29.35 & 33.75 & 41.49 & 24.11 & 18.87 \\
\hline $\mathrm{Sm}$ & 6.23 & 5.31 & 5.71 & 4.04 & 5.15 & 5.31 & 5.92 & 7.38 & 5.11 & 4.33 \\
\hline $\mathrm{Eu}$ & 0.96 & 1.08 & 0.8 & 0.67 & 0.77 & 0.88 & 0.9 & 1.02 & 0.6 & 0.45 \\
\hline $\mathrm{Gd}$ & 5.54 & 4.81 & 5.11 & 3.56 & 4.58 & 4.83 & 5.22 & 6.58 & 4.75 & 4.15 \\
\hline $\mathrm{Tb}$ & 0.75 & 0.64 & 0.67 & 0.45 & 0.66 & 0.68 & 0.73 & 0.92 & 0.77 & 0.7 \\
\hline Dy & 3.74 & 3.15 & 3.31 & 2.18 & 3.39 & 3.57 & 3.62 & 4.74 & 4.32 & 4.08 \\
\hline Ho & 0.68 & 0.56 & 0.59 & 0.38 & 0.62 & 0.66 & 0.65 & 0.85 & 0.81 & 0.77 \\
\hline Er & 1.99 & 1.61 & 1.74 & 1.12 & 1.76 & 1.87 & 1.84 & 2.42 & 2.35 & 2.22 \\
\hline $\mathrm{Tm}$ & 0.28 & 0.21 & 0.23 & 0.15 & 0.24 & 0.25 & 0.25 & 0.32 & 0.34 & 0.32 \\
\hline $\mathrm{Yb}$ & 1.83 & 1.39 & 1.52 & 0.99 & 1.58 & 1.65 & 1.62 & 2.15 & 2.18 & 2.07 \\
\hline $\mathrm{Lu}$ & 0.28 & 0.21 & 0.23 & 0.15 & 0.23 & 0.24 & 0.24 & 0.32 & 0.33 & 0.31 \\
\hline
\end{tabular}




\begin{tabular}{|c|c|c|c|c|c|c|c|c|c|c|}
\hline Hf & 4.64 & 5.24 & 5.38 & 4.04 & 3.89 & 3.37 & 4.29 & 4.59 & 4.37 & 3.46 \\
\hline $\mathrm{Ta}$ & 1.49 & 1.15 & 1.4 & 1.13 & 1.34 & 1.27 & 1.41 & 1.56 & 1.97 & 2.06 \\
\hline $\mathrm{Pb}$ & 17.67 & 70.68 & 218 & 106 & 50.62 & 21.49 & 196 & 98.89 & 33.68 & 39.97 \\
\hline Th & 22.33 & 15.71 & 21.5 & 16.36 & 21.77 & 23.74 & 21.38 & 29.83 & 25.5 & 24.56 \\
\hline $\mathrm{U}$ & 2.48 & 4.26 & 3.18 & 2.12 & 1.97 & 1.7 & 1.69 & 2.95 & 2.84 & 5.08 \\
\hline$\Sigma \mathrm{REE}$ & 218.99 & 209.82 & 211.35 & 156.65 & 168.31 & 161.7 & 193.72 & 227.26 & 142.94 & 110.88 \\
\hline$(\mathrm{La} / \mathrm{Yb})_{\mathrm{N}}$ & 21.2 & 28.52 & 25.01 & 28.29 & 16.58 & 16.29 & 20.12 & 17.82 & 9.86 & 7.94 \\
\hline $\mathrm{Eu} / \mathrm{Eu}^{*}$ & 0.5 & 0.65 & 0.45 & 0.54 & 0.48 & 0.53 & 0.49 & 0.45 & 0.37 & 0.32 \\
\hline${ }^{87} \mathrm{Rb} /{ }^{86} \mathrm{Sr}$ & 11.893 & 16.052 & 16.879 & 25.168 & 6.616 & 5.131 & 7.663 & 5.515 & 13.761 & 24.661 \\
\hline${ }^{87} \mathrm{Sr} /{ }^{86} \mathrm{Sr} \pm 2 \sigma$ & & & & & $0.725540 \pm 6$ & $0.720365 \pm 11$ & $0.723483 \pm 8$ & $0.720365 \pm 11$ & & \\
\hline$\left({ }^{87} \mathrm{Sr} /{ }^{86} \mathrm{Sr}\right)_{\mathrm{i}}$ & & & & & 0.710594 & 0.708774 & 0.706174 & 0.707908 & & \\
\hline${ }^{147} \mathrm{Sm} /{ }^{144} \mathrm{Nd}$ & 0.1044 & 0.091 & 0.0954 & 0.0955 & 0.108 & 0.1093 & 0.106 & 0.1075 & 0.1281 & 0.1386 \\
\hline${ }^{143} \mathrm{Nd} /{ }^{144} \mathrm{Nd} \pm 2 \sigma$ & $0.512033 \pm 5$ & $0.512025 \pm 4$ & $0.512046 \pm 5$ & $0.512028 \pm 4$ & $0.512027 \pm 4$ & $0.512037 \pm 4$ & $0.512025 \pm 4$ & $0.512072 \pm 6$ & $0.512046 \pm 5$ & $0.512063 \pm 4$ \\
\hline$\varepsilon_{N d}(t)$ & -10 & -9.9 & -9.5 & -9.9 & -10.1 & -10 & -10.1 & -9.2 & -10.2 & -10 \\
\hline $\mathrm{T}_{\mathrm{DM} 2}(\mathrm{Ma})$ & 1757 & 1747 & 1721 & 1749 & 1770 & 1757 & 1770 & 1699 & 1774 & 1763 \\
\hline M & 0.92 & 0.91 & 0.74 & 0.93 & 1.23 & 1.25 & 1.18 & 1.27 & 1.07 & 0.92 \\
\hline $\mathrm{T}_{\mathrm{Zr}}\left({ }^{\circ} \mathrm{C}\right)$ & 807 & 824 & 837 & 817 & 786 & 770 & 797 & 792 & 794 & 775 \\
\hline
\end{tabular}

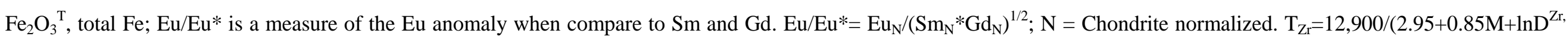

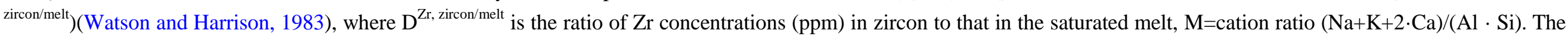
geothermometer is calibrated for $\mathrm{M}=0.9$ to 1.7 . 
Table 4 Compilation of isotope age for the Late Mesozoic volcanism in the northeastern Jiangxi.

\begin{tabular}{cccccc}
\hline Province & Location & Formation & Method & Age(Ma) & Reference \\
\hline Jiangxi & Tianhuashan & Ehuling & Rb-Sr & $101.3 \pm 4.1$ & Xu et al., 2001 \\
Jiangxi & Tianhuashan & Ehuling & K-Ar & 102 & Xu et al., 2001 \\
Jiangxi & Tianhuashan & Ehuling & Rb-Sr & $129.7 \pm 8.9$ & Xu et al., 2002 \\
Jiangxi & Tianhuashan & Ehuling & LA-ICP-MS & $161.8 \pm 1.4$ & Xu et al., 2013 \\
Jiangxi & Tianhuashan & Ehuling & LA-ICP-MS & $146.6 \pm 2.2$ & Qiu et al., 2013 \\
Jiangxi & Tianhuashan & Ehuling & LA-ICP-MS & $140 \pm 1$ & Su et al., 2014 \\
Jiangxi & Tianhuashan & Ehuling & LA-ICP-MS & $137 \pm 1$ & Su et al., 2014 \\
Jiangxi & Tianhuashan & Ehuling & SHRIMP U-Pb & $157.8 \pm 1.6$ & Meng et al., 2012 \\
Jiangxi & Tianhuashan & Ehuling & SHRIMP U-Pb & $157.2 \pm 1.5$ & Meng et al., 2012 \\
Jiangxi & Tianhuashan & Ehuling & SHRIMP U-Pb & $158.2 \pm 1.8$ & Meng et al., 2012 \\
Jiangxi & Huanggangshan & Ehuling & SHRIMP U-Pb & $131 \pm 2$ & Qiu et al., 2011 \\
Jiangxi & Huanggangshan & Ehuling & SHRIMP U-Pb & $138 \pm 1$ & Qiu et al., 2011 \\
Jiangxi & Shengyuan & Ehuling & Ar-Ar & $122.6 \pm 1.0$ & Zhang, 2000 \\
Jiangxi & Shengyuan & Ehuling & K-Ar & $127 \pm 6$ & Zhang, 2000 \\
Jiangxi & Xiangshan & Ehuling & Single-zircon U-Pb & $129.5 \pm 7.9$ & Zhang and Li, 2007 \\
Jiangxi & Xiangshan & Ehuling & Rb-Sr & $136 \pm 3$ & Zhang, 1996 \\
Jiangxi & Xiangshan & Ehuling & Rb-Sr & 140.7 & Zhang, 1996 \\
Jiangxi & Xiangshan & Ehuling & Ar-Ar & $141.2 \pm 1.5$ & Zhang, 1996 \\
Jiangxi & Xiangshan & Ehuling & LA-ICP-MS & $134.1 \pm 1.6$ & Yang et al., 2013 \\
Jiangxi & Xiangshan & Ehuling & LA-ICP-MS & $135.0 \pm 2.0$ & Yang et al., 2013 \\
Jiangxi & Shixi & Ehuling & Ar-Ar & 141.8 & Zhang, 1996 \\
ZheJiang & Xujiadun & Ehuling & SHRIMP U-Pb & $138.0 \pm 2.4$ & Zhang et al., 2009 \\
Jiangxi & Tianhuashan & Ehuling & LA-ICP-MS & $130.4 \pm 1.1$ & This study
\end{tabular}




\begin{tabular}{cccccc} 
Jiangxi & Tianhuashan & Ehuling & LA-ICP-MS & $133.3 \pm 1.2$ & This study \\
Jiangxi & Tianhuashan & Ehuling & LA-ICP-MS & $137.5 \pm 1.2$ & This study \\
Jiangxi & Tianhuashan & Ehuling & LA-ICP-MS & $137.5 \pm 1.3$ & This study \\
Jiangxi & Tianhuashan & Ehuling & LA-ICP-MS & $138.4 \pm 1.3$ & This study \\
Jiangxi & Tianhuashan & Daguding & K-Ar & $112-123$ & Xu et al., 2001 \\
Jiangxi & Tianhuashan & Daguding & LA-ICP-MS & $160.8 \pm 1.9$ & Qiu et al., 2013 \\
Jiangxi & Tianhuashan & Daguding & LA-ICP-MS & $161.0 \pm 1.0$ & Wang et al., 2013 \\
Jiangxi & Tianhuashan & Daguding & LA-ICP-MS & $144 \pm 1$ & Su et al., 2014 \\
Jiangxi & Tianhuashan & Daguding & LA-ICP-MS & $142 \pm 1$ & Su et al., 2014 \\
Jiangxi & Shengyuan & Daguding & Rb-Sr & $141.2 \pm 9.9$ & Zhang, 2000 \\
Jiangxi & Shengyuan & Daguding & Rb-Sr & $138 \pm 8.8$ & Wu et al., 2011 \\
Jiangxi & Xiangshan & Daguding & LA-ICP-MS & $136.4 \pm 1.5$ & Yang et al., 2013 \\
Jiangxi & Xiangshan & Daguding & LA-ICP-MS & $136.8 \pm 2.5$ & Yang et al., 2013 \\
Jiangxi & Xiangshan & Daguding & LA-ICP-MS & $137.3 \pm 0.9$ & Yang et al., 2013 \\
Jiangxi & Tianhuashan & Daguding & LA-ICP-MS & $151.6 \pm 4.1$ & This study \\
Jiangxi & Tianhuashan & Daguding & LA-ICP-MS & $155.0 \pm 2.2$ & This study \\
Jiangxi & Tianhuashan & Daguding & LA-ICP-MS & $155.9 \pm 1.8$ & This study \\
Jiangxi & Tianhuashan & Daguding & LA-ICP-MS & $158.3 \pm 1.7$ & This study \\
Jiangxi & Tianhuashan & Daguding & LA-ICP-MS & $158.9 \pm 1.5$ & This study \\
Jiangxi & Tianhuashan & Daguding & LA-ICP-MS & $159.4 \pm 2.4$ & This study \\
\hline
\end{tabular}




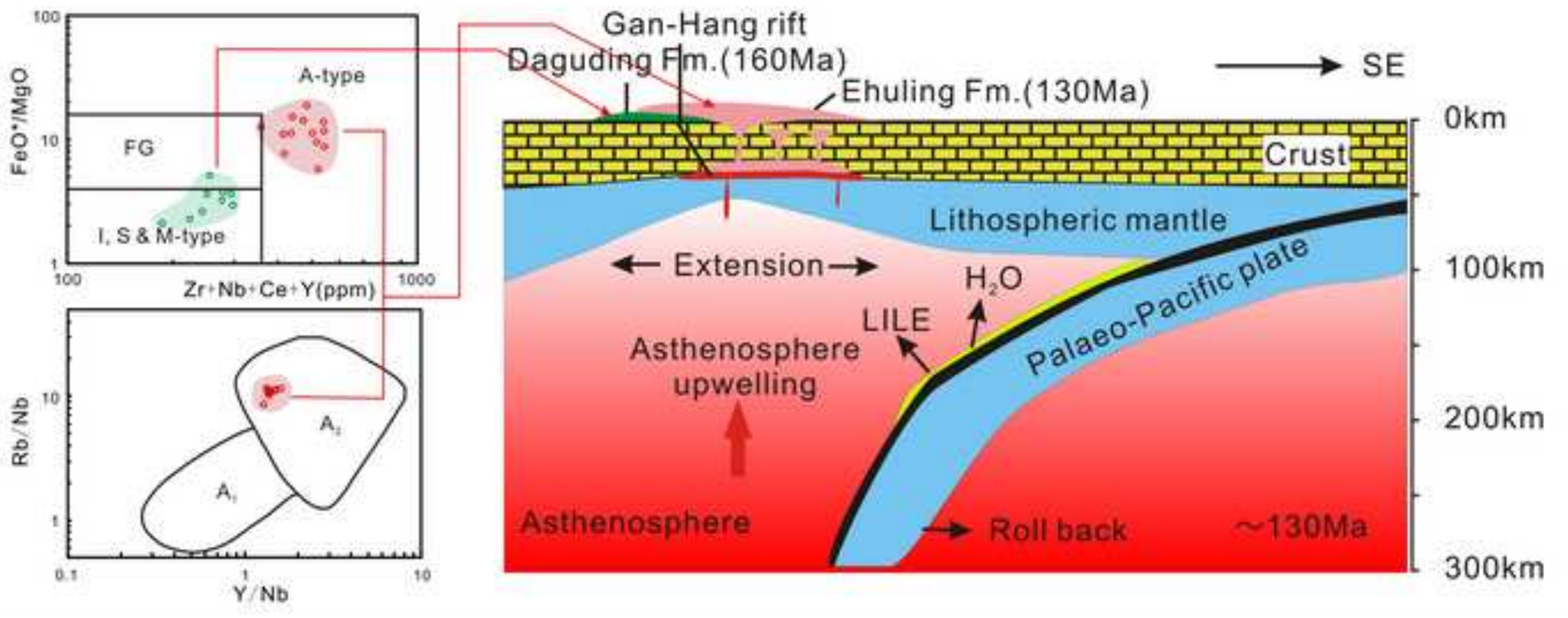

